\title{
Statutory Violations and Equitable Discretion
}

\author{
Zygmunt J.B. Plater $†$
}

Equity, that ancient and amiable dowager of Anglo-American law, often appears to have ambled through the twentieth century free of the stress and strains that have belabored the common law. A closer analysis of the practice and logic of equity in the modern statutory context, however, undercuts that appearance of immutability. The resulting recasting of equitable doctrines has important implications, not only for equity theory, but also for contemporary legal analysis of administrative law, the relationship between courts and legislatures, and modern pluralistic democracy. ${ }^{1}$

Today's equity treatises nevertheless remam largely grounded in the classic common law litigation setting. ${ }^{2}$ In part, no doubt, this is because equity, unlike the common law, has rarely been subjected to direct, specific reforins. While the common law has absorbed major dislocations in its settled doctrines-through judge-made revolutions like those in products liability and modern landlord-tenant law and statutory retoolings like the Uniforn Commerical Code-equity, as a peculiarly procedural assemblage of remedy doctrines, has sustained

$\dagger$ Visiting Professor, Boston College Law School (Professor after Sept. 1, 1982); Professor of Law, Wayne State University. A.B. 1965, Princeton University; J.D. 1968, Yale University; LL.M. 1974, University of Michigan. This Article belongs to that species of academic work which derives from prior hitigation efforts. The issue analyzed here first arose in the course of the author's hitigation in TVA v. Hill, 419 F. Supp. 753 (E.D. Tenn. 1976), rev'd, 549 F.2d 1064 (6th Cir. 1977), affd, 437 U.S. 153 (1978) (the Tellico Dam case). It is hoped, however, that the Article avoids the shortcomings of the genre by exploring theories of equity far beyond the scope of the Hill litigation, by extensive rethinking in the nonadversarial context of academia, and by the passage of time. A nunber of helpful colleagues have contributed to the shaping of this piece, among whom Robert Abrams, Irene Berkey, Mary Ann Glendon, Arthur Lombard, William Pierce, Joseph Sax, and Richard Sullivan deserve special thanks, with none of the blame for errors that remain.

1. The analysis here presented concerns itself primarily with the federal statutory context but applies equally to the enforcement of state statutes, since it is based on distinctions drawn from traditional equity cases and general principles of separation of powers.

2. E.g., D. DoBBS, REMEDIES $24 \mathrm{nn} .2-3$ (1973). Modern equity treatises do, of course, recognize the existence of statutes, but do not address the extent to which those statutes quahitatively change equity practice. See, e.g., O. Fiss, InJunCtions chs. 1(1)(E), 2, 3 (1972); 7 J. MOORE, MOORE'S FEDERAL PRACTICE IT] 65.18[3], 65.33-.140 (2d ed. 1980) (noting that statutes declare the public interest, which is part of the courts' equitable concern, and that in some statutory cases courts enjom statutory violations, and in others they do not. The treatise does not analyze the issues addressed here). 
few basic changes. To be sure, modern statutes and twentieth century conditions have cast equity's substantive jurisdictions in the areas of divorce, trusts, and decedent's estates into new forms, but even there the judicial flexibility that is the essence of equity lies relatively undisturbed. ${ }^{3}$ When judges seek precedential authority for modern tort, contract, and property cases, they only rarely find it relevant to cite cases from a hundred or even fifty years ago. For equity cases, lowever, the nineteenth century is still thought to provide relevant guidance. ${ }^{4}$

In larger part, lowever, the equity treatises' nonstatutory focus is attributable to a simple failure to take full account of modern governmental processes. Modern times-the vast complexities and consequences of a corporate economy, space-age technology, the legislative and administrative processes of the regnlatory state-have altered the workings of equity im modern court practice even if the rlietoric of courts and scholars remams largely unchanged. It is time that our analysis and understanding of equitable doctrimes be conformed to their reality, especially im the context of modern statutory law.

To analyze equity in the modern statutory settimg is to tread on the toes of one of the most venerable formulas of equitable jurisprudence: that an appeal to equity is always an appeal to a court's discretion to balance the equities. But this maxim, an accurate description of the role of equity im the classic common law cases, ${ }^{5}$ is simply not an accurate description of its role in the face of statutory commands.

This Article examines the role of equitable discretion im the modern statutory context. It begims im Part I with a proposition tliat can be as unsettling to tramed legal mimds as it is self-evident to tliose without the benefit of a legal education: that a court has no discretion or au-

3. If bankruptcy is regarded as being within the traditional equitable jurisdiction, it undoubtedly has become the most regimented and codified part of equity, denonstrating a situation where the contemporary complexity of commercial enterprises has simply outstripped the old law. It should be noted, however, that while bankruptcy sounds in equity, Bank of Marin v. England, 385 U.S. 99, I03 (1966), it originated from statutory, not chancery, antecedeuts. I H. REMINGTON, BANKRUPTCY LAW 3, 31 (1908).

4. For cxample, the case of Tulk v. Moxhay, 41 Eng. Rep. 1143 (1849), is still often cited as the basis of modern holdings in the field of equitable servitudes. E.g., Hunt v. Del Collo, 317 A.2d 545, 549 (Del. 1974); Silver Blue Lake Apartments Inc. v. Silver Blue Lake Homeowners Assoc., 245 So. 2d 609, 611 (Fla. 1971); Steuart Transp. v. Ashe, 269 Md. 74, 91, 304 A.2d 788, 798 (1973). The case of Lumley v. Wagner, 42 Eng. Rep. 687 (1852), in which equity did not force an opera singer to sing, and the related case of Lumley v. Gye, 118 Eng. Rep. 748 (1853), are frequcntly citcd in specific performance cases. See, e.g., Sugerman v. Jim Dandy Co., 286 Ala. 295, 304, 239 So. 2d 545, 553 (1970); Lemat Corp. v. Barry 275 Cal. App. 2d 671, 678, 80 Cal. Rptr. 240, 245 (1969); Northern Del. Indus. Dev. Corp. v. Bliss, 245 A.2d 431, 434 (Del. 1968).

5. The term "common law cases" is uscd in this Article as a shorthand form to mean litigation based on common law rather than statutory causes of action, although equitable remedies as well as damages are sought. 
thority to exercise equitable powers so as to permit violations of statutes to continue.

Part II explores the traditional forms of equitable discretion as they exist in the classic common law context. Properly viewed in this context, equity has three distinct and separable balancing components: a threshold balance, a balance on the question of abatement or required conduct, and finally a balance in tailoring equitable remedies to effectuate the second determination.

In Part III, the Article deinonstrates how separating equitable balancing into its three components permits conventional notions about the scope of equitable discretion to be reconciled with modern statutory imperatives. Viewed in hight of the three separate elements of equitable balancing, the holdings im statutory cases reveal a consistent pattern. Courts defer to the legislature's statutory commands and proscriptions-the second stage of equitable balancing. On the other hand, they generally retain discretion in making the threshold determinations and in tailoring reinedies, and statutes only rarely take over these two equitable functions. Over the years, however, the courts have deinonstrated confusion and vagueness in their discussions of equity and statutory violations, particularly regarding Hecht Co. v. Bowles, ${ }^{6}$ the leading case. Part III presents a clarifying analysis of the cases.

Finally, Part IV analyzes the consequences of equitable deference to statutory mandates. Judicial enforceinent of statutory provisions, even where violations appear to be inere technicahities, in effect transfers each controversy to the legislative forum. Such remands to the legislature comport with modern theories of plurahism and participatory democracy. The process also reinforces the constitutional separation of powers doctrine as it exists in the modern state.

I

\section{A Modern Equity Proposition}

The problems of traditional equitable discretion in the nodern context are most drainatically presented by the difficult but illuminating case of a defendant found violating a specific statutory ternn, especially where the trial judge considers the violation trivial or a mere anachronisin. The judge may also be convinced that the defendant is committing the violation while engaged in an enterprise of overriding public importance. If the same defendant were involved in purely nonstatutory hitigation, the court could simply weigh the public importance of the defendant's activity against the plaimtiff's interest. As a result of this classic balancing of the equities, the court could permit the defend-

6. 321 U.S. 321 (1944), discussed infra in text accompanying notes 73-112. 
ant's otherwise tortious or illegal conduct to continue. ${ }^{7}$ But what happens in the statutory context? A review of old and new equity cases and a consideration of the tripartite nature of the inodern state leads to a contrary proposition: When a court in equity is confronted on the merits with a continuing violation of statutory law, it has no discretion or authority to balance the equities so as to permit that violation to continue. ${ }^{8}$

This conclusion may upset generally accepted notions of equity jurisdiction, however outdated or unrealistic they may be. Yet this proposition is far less disturbing than the contrary assertion that courts, balancing equities, have the power to permit particular defendants to continue to violate statutes with impunity. This alternative would constitute a remarkably direct extension of the judicial function into the process of amending legislation.

When the classic doctrines of equitable discretion confront the reahty of clear statutory violations, the time-honored dogma of balancing cannot survive without some sympathetic analytical retooling. Far from stripping the courts of their traditional powers of equitable discretion, however, ${ }^{9}$ the analysis advanced here draws distinctions that preserve a discretionary role for equity courts even where statutes are involved. As Part II will demonstrate, close analysis reveals that the traditional balance of equities actually subsumes three separate bal-

7. This occurs in cases where common law liability for damages is found but no abatement is required. See infra notes 43-62 and accompanying text. The traditional balancing of the equities, of course, verified the respective interests of and consequences to the public as well as those of the private parties before the tribunal. See McClintock, Discretion to Deny Injunction Against Trespass and Nuisance, 12 MinN. L. Rev. 565 (1928).

8. Throughout this analysis it is assumed that the court has determined through a process of statutory construction and application of statutes to particular facts that a statutory violation exists. The Article does not purport to analyze the process of statutory interpretation, a pathway of craft and mystery that has been well scouted by others. E.g., H. HART, JR. \& A. SACKS, THE Legal Process: Basic Problems in the Making and Application of LaW ch. VII (1958). It is sufficient to note that the process offers courts numerous opportumities to define, shift, and recast the language of statutes as they apply in particular cases. In addressing those situations where discrete violations have been defined and found to exist on particular facts, this Article presumes that courts have successfully resisted the teinptation to use the statutory interpretation process disingenuously by defining a statutory violation out of existence so as to avoid potential constraints ou their equitable discretion.

Not all, nor even most, statutes provide such specific prohibitions as to require such equitable deferencc. Many statutes build in flexibility through the delegation of ruleinaking and adjudicatory power to administrative agencies. Many statutes do, however, impose direct mandates. Even where such mandates do not exist, the present analysis forms the basic relationship between courts and legislatures.

9. Reaction against the proposition of mandatory compliance has been couched, for instance, in assertions that the proposition "Strip[s] The Court Of Its Inherent Equitable Power To Determine Whether Or Not It Is In The Public Interest To Grant Equitable Relief." Brief for Pacific Legal Foundation as Amicus Curiae at 5, TVA v. Hill, 437 U.S. 153 (1978). 
ances, ${ }^{10}$ only one of which is necessarily preempted by statutory definitions of prohibited conduct. ${ }^{11}$

To say that courts cannot permit statutory violations to continue is not to say that injunctions must issue for all statutory violations. It is perfectly possible, and often desirable, for the courts to assure that statutory compliance occur without issuing an injunction, so long as it is clear that compliance will in fact occur. ${ }^{12}$ Where the judge believes that a statute does not serve the public interest in a particular case, he or she is of course free to say so, but must nevertheless give the law its required effect. In such cases the practical result of statutory enforcement, by injunction or otherwise, will often be a transfer of the controversy to the legislature, which is the proper repository of the power to promulgate statutory exemptions and amendments..$^{13}$

The restriction of statutory balancing to the legislature will, no doubt, be disturbing to many who share our profession's longstanding suspicion of absolutist principles that cannot be compromised and balanced by a court. The mitial instinctive reaction of most attorneys and jurists is to assume that when Congress authorized injunctive relief for statutory violations, it must have intended to incorporate the full dis-

10. A threshold balance, an abatement balance, and the tailoring of effectuating remedies, as analyzed infra in text accompanying notes 36-68.

11. A statute which proscribes particular conduct takes over the job previously held by the courts of determining which conduct must be abated and which may continue. See infra text accompanying notes 193-276.

12. This proposition underlies Hecht Co. v. Bowles, 321 U.S. 321, 326-31 (1944), discussed infra $\mathrm{m}$ text accompanying notes 73-112. It also underlies two recent majority opinions by Chief Justice Burger: TVA v. Hill, 427 U.S. 153 (1978), discussed infra in text accompanying notes 11418, 298-304, and Rondeau v. Mosmee Paper Co., 422 U.S. 49 (1975), discussed infra in text accompanying notes 169-73.

13. This remand to the legislature-a judicial phenomenon which arises in the context of participatory democracy and public interest hitigation, and elsewhere-was first described by Joseph Sax in the context of citizen efforts to bring public trust issues to legislative attention. See J. SAX, Defending THE ENVIRONMENT 175-92 (1971). Judicial deference to statutory commands accordingly serves the continuing trend toward pluralistic participation in American government. This process of internal democratization-first chronicled in Stewart, The Reformation of American Administrative Law, 88 HARV. L. REV. 1667 (1975)-is traceable in a variety of administrative law cases and statutes in the years since the mid-1960's. See, e.g., National Welfare Rights Org. v. Finch, 429 F.2d 725 (D.C. Cir. 1970); Office of Communications of the Umited Church of Christ v. FCC, 359 F.2d 994 (D.C. Cir. 1966) (facilitating citizen intervention in agency proceedings); Scenic Hudson Preservation Corp. v. Federal Power Comm'n, 354 F.2d 608 (2d Cir. 1965), cert. denied, 384 U.S. 941 (1960); Freedom of Information Act, Pub. L. No. 90-23, 81 Stat. 54 (1967) (codified at 5 U.S.C. $\$ 552$ (1976)); Government in the Sunshine Act, Pub. L. No. 94-409, 90 Stat. 1241 (1976) (codified at 5 U.S.C. $\$ 552 b(1976)$ ). To some extent it is possible to discern a retrenchment against pluralistic denocracy in recent cases limiting citizen participation. See, e.g., Verinont Yankee Nuclear Power Corp. v. Natural Resources Defense Council, Inc., 435 U.S. 519 (1978) (holding that the procedural minimums required of agency rulemaking in the 1946 Administrative Procedure Act were actually also procedural maximums where citizen rights were concerned); see also cases cited infra note 17. 
cretion of equity as well. Courts must always be able to compromise statutory violations; they do so all the time.

Beyond the constitutional implications of the contention that courts have the power to override statutes, ${ }^{14}$ one response to reactions against limitations of equitable discretion is to point to the remarkable absence over the years of equity cases permitting statutory violations to continue. It is difficult, if not impossible, to find cases in which courts have permitted proved statutory violations to continue unabated. There have, of course, been literally hundreds of statutory violation cases in which injunctions liave not been issued. Tloose cases, llowever, all fit into one or another category that is consistent with the present proposition.

By far the largest category of statutory violation cases where imjunctions have been demied involves past violations where the courts find that statutory compliance will lienceforth be achieved without injunctive rehef. ${ }^{15}$ A second category involves preliminary proceedings seeking temporary restraining orders or preliminary injunctions. Because such proceedings occur prior to a full hearing on the inerits, it is understandable that these cases do not always result in enforceinent orders against putative violators. ${ }^{16}$ In another class of cases, estoppel or other threshold questions may preclude statutory enforceinent, especially witl regard to criminal statutes. ${ }^{17}$ In these cases the courts bar the question of the need for injunctive rehef from being lieard, so here

14. See infra notes 305-19 and accompanying text.

15. See, e.g., Hecht Co. v. Bowles, 321 U.S. 321 (1944). In the following representative cases, no injunction issued since compliance had been achieved and there was no likelihood of future violations of the subject statute: Wallace v. Cutten, 298 U.S. 229 (1936); Mitchell v. Bland, 241 F.2d 808 (5th Cir. 1957); Jicarilla Apache Tribe v. Supron Energy Corp., 479 F. Supp. 536 (D.N.M. 1979); SEC v. Cenco, Inc., 436 F. Supp. 193 (N.D. Ill. 1977); Goldberg v. Martin, 198 F. Supp. 836 (S.D. Miss. 1961); Mitchell v. Kickapoo Prairie Broadcasting Co., 182 F. Supp. 578 (W.D. Mo. 1960), modified, 288 F.2d 778 (8th Cir. 1961); Henderson v. J.B. Beaird Corp., 48 F. Supp. 252 (W.D. La. 1943).

16. The traditioual standards for issuance of a preliminary imjunction typically imclude consideration of plaintiff's likelihood of prevailing on the merits, the possibility of irreparable harm to plaintiff, the counterbalancing risk of harm to defendant, and the requirements of the public interest. See, eg., Martinez v. Mathews, 544 F.2d 1233, 1242-43 (5th Cir. 1976); Developments in the Law-Injunctions, 78 HARV. L. REv. 994, 1059 (1965) [heremafter cited as Developments]. The extent to which these elements are determined or affected by an alleged statutory violation has not been much commented on, but it would appear that all four elements would be affected by statutory considerations so as to require enforcement in direct proportion to the clarity of the alleged violation. The force of the general equitable proposition analyzed here, in other words, would seein to apply in the preliminary relief context as well.

17. Cf. United States v. Pennsylvania Indus. Chem. Corp., 411 U.S. 655 (1973) (trial court erred in refusing to admit evidence that might establish that the government had affirmatively misled the defendant so that the defendant believed that its actions did not violate the Rivers and Harbors Act, 33 U.S.C. $\$ 407$ (1976)). Prosecutorial discretion also operates to avoid presenting violations to the courts for decision. Where a violated provision of a statute is not directly enforceable by citizen suits, the decision of agencies or public prosecutors not to prosecute provides a 
too they never reach the merits of the alleged violations. ${ }^{18}$ Nor do cases in which federal courts decline to issue injunctions when state proceedimgs are underway or available contradict the proposition, ${ }^{19}$ for again the courts never reach the merits of the claimed violations.

Other major categories where mjunctions have been refused include cases of procedural violations where substantial coinpliance has occurred prior to the resolution of the suit; ${ }^{20}$ cases where the courts have simply concluded that the defendant's actions do not violate the statute at issue; ${ }^{21}$ and cases in which a statute gives a court discretion to permit contimued noncompliance, ${ }^{22}$ vests the court with authority to determine what constitutes a violation in particular circumstances, ${ }^{23}$ or provides for exemptions. ${ }^{24}$ There is also a category of cases in which it is not perfectly clear what the district court actually held with regard to a particular statutory violation. ${ }^{25}$ And in cases where the alleged viola-

major screening function, leaving citizens to their common law remedies. See California v. Sierra Club, 101 S. Ct. 1775 (1981).

18. Such threshold questions, which may effectively nonsuit the plaintiff, involve judicial discretion; the courts accordingly retain the power to ignore clear estoppel situations and grant relief. See generally cases cited infra note 157.

19. Cf. Federal Anti-Injunction Act, 28 U.S.C. $\$ 2283$ (1976) (restricting powcr of fcderal courts to stay state court proceedings); Younger v. Harris, 410 U.S. 37, 44 (1971) (intercsts of "coinity" and "Our Federalism" require that federal courts not enjoin pending state proceedings). See also Burford v. Sun Oil Co., 319 U.S. 315 (1943) (abstention by federal district court appropriate when plaintiff has appropriate state means for vindicating federal constitutional claims).

20. E.g., Realty Income Trust v. Eckerd, 564 F.2d 447 (D.C. Cir. 1977); Essex County Preservation Ass'n v. Campbell, 536 F.2d 956 (1st Cir. 1976).

21. Thus, numerous courts held that the National Environmental Policy Act (NEPA), 42 U.S.C. $\$ \$ 4321-4369$ (1976 \& Supp. III 1979), would not be applied where, even though a federal project did not have a statutorily required impact statement, it was too close to completion for NEPA's procedural requirements to be applied in a manner that would usefully achieve the statutory purposes. This resembles either an estoppel defense or a statutory interpretation implying a sort of retroactive grandfather clause. See infra note 238. Similarly, where a defendant's violation of a statute is de minimis, the courts are likely to find that no violation has occurred. See, e.g., Umited States v. General Foods Corp., 446 F. Supp. 740, 754 n.16 (N.D.N.Y. 1978).

22. The Federal Water Pollution Control Act of 1948, ch. 758, \& 2(d)(7), 62 Stat. 1155, 1157 (current version at 33 U.S.C. $\$ 1251$ (1976)), for example, contamed a total transfer of the abatement question to the courts. See infra text accompanying notes 223-24.

23. See Labor Management Relations Act § 206, 61 Stat. 152, 155 (current version at 29 U.S.C. $\$ 178$ (1976)) (giving court power to enjoin labor strike upon finding that a strike's continuation will "imperil the national health or safety"), discussed infra in text accompanying note 199.

24. The River and Harbors Act of 1899 prohibits the obstruction of navigable waters, 33 U.S.C. $\$ \S 403,407,409$ (1976), but exempts log driving on rivers. Id. $\S 410$, construed in United States v. Kennebec Log Driving Co., 491 F.2d 562, 566 (1st Cir. 1973).

25." In Schultz v. Hartsock, 63 Lab. Cas. (CCH) II 32,344 (M.D. Fla. 1970), for example, the court refused to issue an injunction requiring adequate recordkeeping as mandated by $\S 15$ of the Fair Labor Standards Act of 1938, 29 U.S.C. $\$ \$ 201-214$ (1976). It is not clear that the sawinill's labor violation was not being corrected in good faith, although the judge certainly also seemed to weigh the equity of the government's lack of prior "diligent effort to assist defendant in complying with the technical provision of the . . . Act" in denying an injnnction. $63 \mathrm{Lab}$. Cas. (CCH) at If 32,345. See also Hill v. TVA, 419 F. Supp. 753 (E.D. Tenn. 1976), rev'd with clarification of the findings of fact and law, 549 F.2d 1064, 1069-70 (6th Cir. 1977), affd, 437 U.S. 153 (1978). The 
tion is based on a constitutional rather than a statutory mandate, courts paradoxically possess more discretionary authority to permit delayed or lessened comphiance, for example "with all deliberate speed." 26

Fimally, it is both logical and consistent with the proposition of judicial deference to statutes to recognize that equity courts can refuse to issue mjunctions where comphance is impossible. Like King Canute, equity courts would accomphsh nothing (beyond humbling themselves and diminishing popular respect for their powers) ${ }^{27}$ if they attempted to order the ocean to hold back its waves or rivers to run uphill. ${ }^{28}$ Futility is properly a limitation of equitable discretion, since

most difficult case to analyze in terms consistent with the proposition is Reserve Mining Co. v. EPA, 514 F.2d 492 (8th Cir. 1975), discussed infra in text accompanying notes 220-33. In Reserve Mining the court allowed a delayed injunctive compliance schedule, using reasoning that seeined to turn more on a common law "hazard" standard than on any specific statutory violation.

26. Where the Court determines that a statute or practice is unconstitutional, it often provides a cushion in the enforcement of the new interpretation. For example, where retroactive application of a new constitutional standard of criminal procedure would disrupt the administration of justice and where there has been official reliance on past standards, the Court inay decide to apply it only prospectively. See, e.g., Linkletter v. Walker, 381 U.S. 618 (1965) (limiting the retroactive apphication of Mapp v. Ohio, 367 U.S. 643 (1961)). Where, however, basic procedural rights are involved, the Court may choose to apply the new rule retroactively despite consequent disruptions, as in the aftermath of Gideon v. Wainwright, 372 U.S. 335 (1963). The school desegregation cases required compliance "with all deliberate speed." Brown v. Board of Educ., 349 U.S. 294, 301 (1955) (Brown II). In both types of constitutional cases it can be argued that the new definitions of constitutional principles are judge-made law, interpreting broad old language in the light of evolving inodern realities; lence, courts are in a position to tailor their application. Further, general constitutional primciples derive their specificity froin the interpretations of courts, whereas statutory violations derive from inore specific legislative declarations. Accordingly, there are fewer problems in the nature of lack of notice and estoppel in the statutory than the constitutional context. Even in the constitutional arena the judicial cushion may be problematic. Justice Black once said that the dehiberate speed formula "delayed the process of outlawing segregation" and that it would have been preferable to treat Brown "as an ordinary lawsuit and force that judgment on the counties it affected that minute." Justice Black and the Bill of Rights, CBS News Special, Dec. 3, 1968, quoted in W. LockHART, Y. KAMISAR \& J. CHOPER, Constitutional LAw 1275 (5th ed. 1980). See also R. Woodward \& C. ARMSTrong, The Brethren 38-40 (1979) (describing Justice Black's concern over the South's slow impleinentation of Brown).

27. A judicial apprehension that a decree would be ignored, thereby bringing disrespect to the courts, inay sometime underhe decisions not to issue injunctive relief. By the nature of the problem, however, courts would understandably be reluctant to articulate such grounds for restraint; at any rate, no suclt avowals liave been found. King Canute, it should be noted, did not reap disrespect for his feckless royal command that the waves be stilled; he liad staged the seashore scene as a wry demonstration of his own mortality to silence the flattering sycophants amongst his courtiers. W. Churchill, A History of the ENGlish-Speaking PeOples 140 (1956).

28. See TVA v. Termessee Elec. Power Co., 90 F.2d 885, 894-95 (6th Cir. 1937) ("The court may not command the waters of the Tennessee River and its tributaries to cease their flow.") See also infra notes 261-73 and accompanying text. In National Wildlife Fed'n v. Gorsuch, Civ. No. 79-0915, slip op. (D.D.C. Jan. 29, 1982), the district court found that federal dams violate the Clean Water Act of 1977, 33 U.S.C. $\$ \$ 1251-1376$ (1976 \& Supp. III 1979), if they discharge their water without a statutory permit. The court ordered the government to obtain such permits. If the court had gone on to issue an injunction ordering permitless dams to close their gates and the water discharges to lialt, its order would have been overflowed in fact even before it had a chance 
equity will not command the doing of a vain thing. ${ }^{29}$

In sum, these assorted variations on a theine demonstrate a variety of adjustments to a basic principle, not the undercutting of the essential proposition that equity inust defer to statutory commands. The case law reflects a remarkable, though unheralded, consistency over the past fifty years: cases hold that statutes dispositively define the nature of prohibited and permitted conduct, thereby removing one entire area of discretion froin the courts.

Recogmition of an equitable power to override statutcs would represent a significant expansion of judicial authority beyond its existing limits; it would also require extremely sensitive definitions of limits and standards to the open-ended discretion thereby unleashed..$^{30}$ But there

to be overturned on appeal. This Canute principle appears to be sufficiently self-evident that no court has bothered to state the obvious. An injunction is a functional order rather than a symbolic philosophical act. Since equity is attempting to see that something be done, or not be donerather than issuing pronunciamentos against discerned evils-it would be both useless and unnecessary for a court to command a physical innossibility. For other cases of impossibility, see Moffett v. City of Rock Island, 77 Ill. App. 3d 850, 854, 397 N.E.2d 457, 460 (1969) (state takeover of a major highway project prevented city from building a platted road that liad been promised to adjacent landowner, i.e. a case of legal impossibility); Davenport v. Bankers Life Co., $178 \mathrm{Neb}$. 591,134 N.W.2d 258, 261 (1965) (insured party, being dead, could no longer be ordered to endorse documents necessary for payment to changed beneficiary). Courts also have used the impossibility principle in other nonstatutory cases where comphiance with legal duties would be relatively impossible, in the sense of being unreasonably onerous in light of the benefit conferred. Martin v. New York Life Ins. Co., 104 F.2d 573, 575 (7th Cir. 1939); Mutual Savings Life Ins. Co. v. Cowan, 188 F. Supp. 148, 154 (E.D. Tenn. 1960); Butler v. Butler, 239 A.2d 616, 619 (D.C. Ct. App. 1968).

29. Watterson v. Ury, 5 Ohio C.C. 347,360 (Cir. Ct. 1891), affd, 52 Ohio St. 637, 44 N.E. 1149 (1894), states the principle that equity will not decree a vain act in a diffcrent context, where comphance with the subject trust obligations was impossible because land could no longer be practically used for trust purposes (with no discussion of $c y$ pres principles). The principle that equity will not require the doing of an impossibility is a recurrent maxim. See supra note 28. See also Rust v. Conrad, 47 Mich. 449, 455, 11 N.W. 265, 267 (1882) (Cooley, J.).

30. This is the problem posed by arguments presented by the U.S. Navy in Weinbcrger v. Romero-Barcelo, 102 S. Ct. 88 (1981), granting cert. to Brown v. Roincro-Barcelo, 643 F.2d 835 (1st Cir. 1981), discussed infra in text accompanying notes 243-63. See also infra text accompanying notes 116-18 (discussing Justice Rehnquist's analysis of a district court's power to override statutory provisions).

A striking recent example of the probleinatic assertion that courts may override statutes is presented in Professor Calabresi's absorbing new book, G. CALABRESI, A COMMON LAW FOR THE AGE OF STATUTEs (1982). Professor Calabresi responds to the "statutorization" of our legal system, which derives from this century's "orgy of statute making," by suggesting that courts be allowed to nullify those statutes (new or old) that the judges find to be "anaclironistic." Goimg beyond the custonary judicial rules for desuetude, he defines legal obsolescence as a "lack of fit" or "lack of current legislative support." Although this may oversimplify Calabresi's argument, he is clearly treading on dangerous ground. There are those who would be delighted to argue in court that unany of our civil rights statutes, for example, do not fit modern circumstances in North or South, and that the complexion of Congress has assuredly changed since they were passed. Surely a district court should not be able to step in and relieve descgregation's opponcnts of the burden of amending these civil rights statutes in the more faniliar constitutional manner. Calabresi's argument does not adequately integrate the nature of the modern American lawinaking process: statutes are spawned in political maelstrouns; they often are never again so supported on 
is no apparent need to let that judicial genie out of the bottle. Analysis of equitable theory indicates that such an extension of equitable discretion is as unnecessary as it would be conceptually difficult.

\section{II \\ ANALYZING EQUitable DiscRetion}

\section{A. Historical Origins}

It should not be very controversial to discern a principle in American jurisprudence that courts cannot permit a statutory violation, once proven, to continue unrestrained. Discretion, however, has always lain at the heart of equity jurisdiction, and courts have always had the right and duty to "balance the equities" when requested to issue injunctions. $^{31}$ The present analysis circumscribes the traditional definitions of equitable discretion in a manner that may seen 1 extreme. It would hold that a court has no discretion to allow statutorily proscribed conduct to continue. Where a defendant is intransigent, an injunction abating the defendant's conduct nust issue.

The consternation this proposition engenders may be a tribute to the cloudiness with which the subtleties and character of equitable jurisprudence are understood. Equity springs froni ancient sources, and in many regards retains the principles of its past. It is also, however, a component part of our vastly evolved nodern legal systein. It should not be surprising that equity has developed apphications and nuances that add to and differ from those of past centuries, nor that modern statutes have made a major difference.

Traditional notions of equitable discretion have their origins in the earhest roots of equity. Aristotle's concept of equity was first and foremost the power of the tribunal to override specific rules where particular circumstances seemed to require such dispensation. "What

the floor of the legislature as the day they pass, yet they continue to provide the accepted matrix for future legislative battles over amendments and new legislation, not to mention for subsequent statutory interpretation by the courts. To permit judges to intrude their own judgments of "fit" and "legislative support" raises far more definitional, procedural, and philosophical problems than answers.

31. There is one theme that runs throughout injunctive litigation and often gives it romance. That is discretion. The cases abound with quaint statements, sucle as that an application for an injunction is an appeal to the Chancellor's conscience; that the injunction is a discretionary remedy or that a court of equity has the inherent power to create and fashion a flexible remedy.

O. Fiss, supra note 2, at 74. That flexibility, Fiss notes, led to Selden's "well-known crack" that equity varies like the Chancellor's foot. Id. In Truly v. Wanzer, 46 U.S. (5 How.) I41, 142 (1847), the Court observed:

There is no power, the exercise of which is more delicate, which requires greater caution, deliberation, and sound discretion, or inore dangerous in a doubtful case, than the issuing of an mjunction. It is the strong arm of equity, that never ought to be extended, unless to cases of great injury .... 
Aristotle had in mind when he analyzed the concept of 'equity' and its relationship to justice was simply the 'rectification of law where it fails through generahty.' "32 Equity as translated into the jurisprudence of the Enghsh chancellors was likewise an appeal to the conscience of the tribunal, an articulation of principles of fairness or morahty that were specifically designed to exempt defendants from comphance with the harshness of rigid legal rules. ${ }^{33}$

Equity grew far beyond its dispensation function, of course, developing the special remedies that today are its most visible attribute. Still, however, equity was dedicated to the implementation of an overarching law of morally-tinged fairness and ethics to be applied when legal rules fell short. The mjunctive order, issued by the church-based equity courts, was an extraordmary remedy. It was reserved, at least in theory, for those cases where courts operating under rules of law would not adequately protect plaintiffs from being unfairly had by defendants. At that poimt, equity would step in and go beyond the law.

A special perspective of balance and relativity has characterized the development of equity law. In Aristotehan terms it was a balance between the citizen violating a particular rule and the more general societal context in which other facts or norms might excuse the violation. Primciples of relativity also governed application of the injunction as it developed over the years. If plaintiffs could prove a cause of action at cominon law, yet felt that the common law would madequately redress their injuries, an appeal to equity was still available. ${ }^{34}$ But before the injunction would be issued, plamtiffs, in response to affirmative defenses, had to satisfy tests of relativity between themselves and defendants that were not required at law: a reasonable alacrity in suing, relatively clean hands, a favorable balance of convenience, and the like. Out of these primciples of relativity came the touchstone phrase "balancing the equities" that has so characterized and beclouded debates over equity both in the past and present.

32. O. Fiss, supra note 2 , at 75 .

33. See T. Plucknett, A Concise History of the Common LAw 685 (5th ed. 1956); Vinogradoff, Reason and Conscience in Sixteenth Century Jurisprudence, 24 LAW Q. REv. 373 (1908). The very term "equity" was not generally used until the 17th century. O. Fiss, supra note 2, at 10-13; 1 J. POMEROY, EQUITY JuRISPRUDENCE 5-9 (5th ed. 1941).

34. Equitable remedies originally were regularly available in situations where there was no "legal," or common law, cause of action. This effeetively combined equitable findings of liability and abatement. Today it is rare to find such a free floating equitable cause of action beyond such equity fields as trusts, probate, and hens, which, of course, have been codificd. One of the rare modern examples of an injunction issued without a basic cause of action in the field of property litigation is the unreported Florissant Fossil Beds case. Defenders of Florissant, Inc. v. Park Land Co., No. $403-69$ (10th Cir. July 29, 1969), discussed in V. YANNACONE, ENVIRONMENTAL RIGHTS AND REMEDIES § 2.9, at 39 (1972). See also Parker v. United States, 448 F.2d 793 (10th Cir. 1971) (injunction against logging in potential wilderness area issued without statutory violation), cert. denied, 405 U.S. 989 (1972). 
A vast array of discretionary equitable concepts has been included over the years in the concept of balancing the equities: laches, estoppel, balance of hardships, clean hands, balancing of comparative utilities, consideration of the public interest, weighing the adequacy of legal remedies, irreparability, the balance of convenience, and the tailoring of remedies. All of these principles require equitable relativity and discretion in their application-a comparison of the circunistances of plaintiffs, defendants, and frequently of society at large.

Often, however, the term "balance of equities" is used to denote only a balancing of private and public interests, thereby obscuring all the other balances of the parties' relativity. The inconsistency and vagueness with which the tern is sometimes used argue for acknowledgment of the term's all-inclusive scope or its rejection in favor of the more straightforward concept of discretion. The imprecision of terminology is of unore than academic concern. When courts and commentators fail to specify what particular aspects of the elenients available for balancing they are including within the coinprehensive term "balancing the equities," they set the stage for significant imsunderstanding and conflict: any constraint on a single element of the equitable balance appears to endanger the heart of the equity jurisdiction. And any rule that seems to infringe on a court's freedoun to "balance the equities" is seen as a threat to a time-honored system which "eschews mechanical rules . . . [and] depends on flexibility." 35

\section{B. Equitable Discretion in the Common Law: Dissecting the Concept of "Balancing the Equities"}

Equity's relationship to the common law over the centuries provides the analytical filter through which inost commentators describe and dissect equitable jurisdiction. Understandably, then, the common law colors the analysis of equity when statutes are involved. In fact, the present analysis of judicial discretion limited by statute fits coinfortably into the traditional law of equity. It is based upon distinctions found in the old law itself.

When equity's application in traditional common law cases is subjected to careful analysis, some basic clarifications emerge. Analytically it can be argucd that the unbrella terms "balancing the equities"

35. Holmberg v. Armbrecht, 327 U.S. 392, 396 (1946). The existence of broad based discretion, of course, does not mean that equity does not have its own rules. Its rules and canons are many and often contradictory. I am imdebted to the useful discussion of early equity that appears in Winner, The Chancellor's Foot and Environmental Law: A Call for Better Reasoned Decisions on Environmental Injunctions, 9 ENVTL. L. 477, 479-85 (1979). Winner, however, asserts a very different view than that presented here of judicial discretion in the face of statutory violations, largely based on his reading of NEPA cases. Id. at 506-10, discussed infra in text accompanying notes $235-42$. 
and "equitable discretion" obscure what are really three separate areas of balancing, three different functions fulfilled by three different types of equitable relativism. The three areas are:

1. Threshold Balancing, based in both law and equity, which tests whether plaintiffs can maintain their actions. This stage includes questions of laches, clean hands, other estoppels, the lack of an adequate remedy at law, proof of irreparable harm, and similar issues.

2. The Determination of Contending Conducts ascertains which conduct will be permitted to continue and which will be subordinatcd. It often involves the question of abatement, a separate issue from the question of liability for past injuries to protected interests.

3. Discretion in Fashioning Remedies involves a process of tailoring remedies to implement the second stage determination of contending conducts.

Consider, for example, the relatively simple field of private nuisance torts where equity has traditionally played an active role. The classic Ducktown Copper ${ }^{36}$ case demonstrates all three of equity's distimctly different roles. In that turn-of-the-century case, the court had to deal with an early example of an environmental tradeoff. The smelting industry was getting underway in the foothills of southeastern Tennessee and northern Georgia. It was likely to provide sizable revenues for the entrepreneurs of Atlanta and Chattanooga, jobs for local residents, and copper and other materials for the nation's industrial econony. The copper ore was mined in nearby hills, then sinelted in large openair piles layered with firewood and coal. This firing process, however, produced acidic "sulphurectic" air emissions that eventually turned nearly a hundred square miles of hills into a remarkably stark, denuded desert, its topsoil slowing washing away down sterile, chenricalladen streams. ${ }^{37}$ The plaimtiffs were farmers whose fields and orchards began to die as the sinelting got underway.

The Tennessee high court held that the sinelting was a continuing private nuisance, but after long and careful deliberation allowed the defendant industries to continue operations despite their drastic impact upon the plaintiffs' land and livelihood. The court required ouly that the mills compensate the plaimtiffs for their losses. ${ }^{38}$ In common par-

36. Madison v. Ducktown Sulphur, Copper \& Iron Co., 113 Tenn. 331, 83 S.W. 658 (1904).

37. Much of the land has been reclaimed over the past two decades, although about 20 square miles are still marked on the Tennessee State Planning Office's cadastral survey land use map as "barren lands." Tennessee State Planning Office Map: Tennessee Land Use (1973).

38. 113 Tenn. at $367-68,83 \mathrm{~S}$.W. at 667 . This result could be explained merely as a finding that plaintiffs' injuries were adequately remedied at law, but the traditional uniqueness of land, see DeFuniak, Contracts Enforceable in Equity, 34 VA. L. Rev. 637, 643 (1948), and the court's extended discussion of a balancing of the importance of the parties' respective conduct indicate otherwise. 
lance, it awarded legal coinpensatory daniages but denied any injunctive remedy, based on a balancing of equities.

The Ducktown court certainly balanced the equities. Analytically, however, it did so not once but thrice.

\section{Threshold Balancing}

The first type of balancing addresses threshold questions which plaintiffs must survive if a cause of action is to be heard. Some issues appear in the guise of affirmative legal defenses: laches and coming to the nuisan'ce, for example, are legal defenses grounded in principles of equitable estoppel. Other issues-clean hands, additional estoppel principles, proof of irreparable harm, and the inadequacy of legal remedies-are more specifically equitable, brought to bear only where the plaintiff seeks equitable renredies. ${ }^{39}$ Each of these threshold issues involves comparisons and balances that are part of the longstanding discretionary processes of equity. The Ducktown court inade several such determinations, excluding some plaintiffs on laches grounds as to certain defendants, ${ }^{40}$ confirming their rights to sue as to others, ${ }^{41}$ and noting imjuries to land ${ }^{42}$ that analytically made equitable reniedies potentially available on grounds of irreparability.

\section{The Determination of Contending Conducts}

After plaintiffs survive equity's threshold gauntlet, nonstatutory hitigation moves to the application of rules of conduct. The major discretionary function of the equity court of this second stage is the determination of whether the defendant's conduct will be permitted to contimue. To reach this abatement determination, however, courts must first consider issues of hability.

39. That these elements involve classic equity balances is hard to doubt. The laches defense is available, for example, when "such changes have taken place in the position of the parties relative to the subject matter of the litigation as to render it inequitable to permit the enforcenent of rights." Norman v. Boyer, 111 Colo. 531, 535, 143 P.2đ 1017, 1018 (1943) (quoting DuBois v. Clark, 12 Colo. App. 220, 231, 55 P. 750, 754 (1898)). The relativity of the clean lands doctrine is demonstrated in Leo Feist v. Young, 138 F.2d 972, 975 (7th Cir. 1943), where a copyright infringer defended on the ground that the holder of the copyright had violated a Wisconsin statute. The court declared: "But the rule is not inexorable that a plaintiff who coines into court with unclean hands is always to be denied relief regardless of other circumstances in the case; for if the defendant has been guilty of conduct more unconscionable and unworthy than that of the plaintiff, the rule may be relaxed." Id. (citing Goodyear Tire \& Rubber Co. v. Overman Cushion Tire Co., 95 F.2d 978, 983, amended per curiam, 95 F.2d at 985 (6th Cir. 1937)).

40. 113 Tenn. at $355-56,83$ S.W. at 664 .

41. Id. at $356-57,83$ S.W. at 664 .

42. Id. at 358-63, 83 S.W. at 664-66. See supra note 38. 


\section{a. Liability}

The initial question is whether defendants are liable at all, whether their conduct is "illegal" under the common law. In this question equity may play a part, though not a cardinal role. The basic common law definition of liability for past conduct may itself be infiltrated by equitable balancing in those jurisdictions that retain soine notion of comparative utilities as an element of the substantive tort, ${ }^{43}$ and not just as part of the remedy question.

There has been a longrunning incestuous relationship between law and equity. Equity, it is true, has generally kept a separate identity as to the availability and issuance of remedies-a heritage traceable to the dispensations of Greek philosophy, the fairness principles of canon law, and the flexibility of orders in chancery. ${ }^{44}$ This separate identity has continued despite the merger of law and equity in England in $1873^{45}$ and in the United States in the $1930^{\prime}{ }^{\prime} .^{46}$ As early as the $1600^{\prime}$ s, however, an interchange of substantive principles between law and equity began. ${ }^{47}$ Some equitable defenses becaine legal defenses by osmosis.

In the field of nuisance law, equity invaded the common law by introducing a comparative weighing of public values in trespass actions. Instead of merely viewing a case as a contest between an injured plaintiff and a causative defendant, an equitable balance came to be incorporated in the cause of action. Thus, in a famous early Enghish air pollution tort case, the injury caused to plaintiff's nose and habitation by a nearby candleinaker's malodorous establishment was ignored by the court of law, which found no tort to exist because "le utilitie del

43. Under earlier precedents, interestingly enough, the law and equity questions were inixed in another fashion: an injunction would automatically issue whenever a nuisance was found. See Holman v. Athens Empire Laundry Co., 149 Ga. 345, 354-56, 100 S.E. 207, 212 (1919); Note, Efficient Land Use and the Internalization of Beneficial Spillovers: An Economic and Legal Analysis, 31 StAN. L. Rev. 457, 464 (1979). This too produced draconian results. In the paradigm case of Whalen v. Union Bag \& Paper Co., 208 N.Y. 1, 101 N.E. 805 (1913), a farmer suffering yearly losses of $\$ 312$ won a nuisance injunction against a $\$ 1$ million pulp plant for polluting a Hudson Valley creek. Though that plant actually was slut down, see Driscoll v. American Hide \& Leather Co., 102 Misc. 612, 614, 170 N.Y.S. 121, 122, affd, 184 A.D. 916, 170 N.Y.S. 1076 (1918), one snspects that successful litigants more often used their injunctions to strike attractive bargains. Where sucl drastic results were possible, however, it may well be that courts often simply declined to find nuisance liability at all, effectively duplicating the results of the utility based definitions of initial liability.

44. See supra text accoinpanying notes 31-35.

45. See Englislı Judicature Act, 1873,36 \& 37 Vict., cl. $66,8 \S 24-25$.

46. In the United States the culmination of the merger of law and equity was marked by the enactınent of the Federal Rules of Civil Procedure. See Act of June 19, 1934, ch. 651, 48 Stat. 1064 (codified at 28 U.S.C. § 2072 (1976)) (Rules Enabling Act).

47. See 5 W. Holdsworth, A History OF ENGlish LAW 299 (1927). 
chose excusera le noisomeness del stink," ${ }^{48}$ a quintessentially equitable distinction.

When courts of law allowed proof of preponderant public utility to nullify a nuisance cause of action, plaintiffs were effectively nonsuited from even a lcgal remedy because of an essentially equitable balancing. Similarly, the tort definitions of substantial mjury and unreasonable action also have turned to some extent on a balancing that reseinbles an equitable rather than a legal standard. ${ }^{49}$ Thus, in some common law actions equitable balancing negated liability where it would otherwise lie. ${ }^{50}$ No matter how substantial plaintiff's injuries, if the public benefits of defendant's operation were greater, there would be no liability.

This draconian approach is being replaced by theories that separate the questions of liability and consequent damages froin those of abatement in intentional tort. ${ }^{51}$ Under this approach, if a suit seeks compensatory damages alone, no further equity issues arise beyond the threshold stage. ${ }^{52}$ More typically, however, plaintiffs in private nuisance cases and in other common law areas seek equitable reniediesparticularly imjunctions-as well as damages. In sucli cases, once tort hability is found, the court turns to the different question of whether defendant's conduct will be abated.

48. J. Stephen, A General View of the Criminal Law of England 106 (1890). The quotation appears to be a version of the bastardized Norman French of Ranketts Case (K.B. 1606), reported in 2 H. ROLLE, Rolle's AbRIDGEMENT 139 (1668): "Si home fait Candells deims un Vill, per que il cause un noysom Sent al Inhabitants, uncore ceo nest ascun [alcun?] Nusans, car le needfulness de eux dispensera ove le noisomness del smell." [If a man makes candles in a town, by which he causes a noisone scent to the inhabitants, still there is no nuisance, for the needfulness of them (the candles) will excuse the noisomeness of the smell.] Also noted in I W. Hawkins, PleAs of THE CROWN 263 (1787) (expresses donbt that such a strict exculpation froin hability should prevail where alternative locations in less populated areas were available, i.e., that the exculpation should depend upon a showing of locational necessity). My gratitude and congratulations to Stefan Riesenfeld, Professor of Law, Boalt Hall, University of Califormia, Berkeley, for having located the original quotation.

49. See O. Fiss, supra note 2, at 76-76; C. Saint German, The Dialogues Between a Doctor of Divinity AND a Student IN THE LAWS OF ENGLAND 77-80, 88-130 (Selden Society ed. 1974) (1st ed. London 1543).

50. 1 J. POMEROY, supra note 33, at ch. 1.

51. The Ducktown view, and the modern trend, is that hability for tort damages is a separate question fron the decision to enjoin. See 113 Tenn. at 358, 83 S.W. at 664 . See also Harrison v. Indiana Auto-Shredders Co., 528 F.2d 1107, 1121-22 (7th Cir. 1976); Rabin, Nuisance Law: Rethinking Fundamental Assumptions, 63 VA. L. REv. 1299 (1977); infra note 60. In negligence based tort liability, of course, the unreasonableness of defendant's action is an elenient of the tort and thus incorporates a balancing of utilities in the initial hability question itself.

52. At the threshold stage in such cases, equitable balancing would be involved only in the cquity based affirmative defenses at law, such as coming to the nuisance, laches, and other estoppels. 


\section{b. Abatement}

Perhaps the grandest pitfall of equity jurisprudence is the tendency for lawyers and judges to equate the judicial decision to abate a defendant's conduct (the second type of equity balancing) with the judicial choice of an mjunction remedy (the third type of equity balancing). But the abatement decision and the choice of remedy are not the same. Abateinent, whether total or partial, is a functional term referring to the decision to restrict the defendant's activity. It is this functional decision that is taken over when a statute declares a mandatory rule of conduct. Injunctions, im their multiple variety, are merely remedial directives designed to impleinent the court's determinations on threshold questions, substantive liability, and future conduct, which may or may not imclude abatemcnt. In fact, of course, the vast majority of abatements are implemented by injunction, and the vast majority of injunctions issued im the private law field are abatements. ${ }^{53}$

The mistaken but understandable confusion of the abatement decision with the choice of remedy reflects the nodern acceptance of injunctions as the normal remedy of choice. But lumping the two together obscures the fact that they constitute two separate judicial decisions. While most judges, attorneys, and commentators discuss equity cases in terms of whether an injunction will issue, the functional result apparently concerns thein more than the particular design of the remedy: Will defendant's conduct be permitted to continue? Which form of conduct will be affirmed for the future and which subordinated? Will the court establish a rule for future conduct that prevents further tort injuries to the plaintiffs or relegate them to sequential damage actions? ${ }^{54}$

The second type of equitable imquiry-the determination of contending conducts-was the heart of the Ducktown case. Since they could not coexist, would the court permit the farms or the mills to continue? The question presented both a legal and an equitable aspect. First, it had to be established that the mills were subject to tort liability as a private nuisance. ${ }^{55}$ The outcome of that inquiry determined the

53. No statistical surveys exist on point, but both conclusions appear intuitively to be true, a position concurred in by Professor Fiss. Telephone conversation with Professor Owen Fiss of Yale Uinversity (Mar. 11, 1982).

54. It is, of course, possible that a crushing damage award against defendants will equally abate the defendant's conduct without an equity decision, but almost by definition damage suits cannot capture all of the real costs of an activity. There is slippage, for example, in the ability to litigate far-flung injuries and in the need to pay attorneys. Abateınent injunctions do prevent all such future damages, albeit without a delicate cost accounting.

55. The Ducktown court had no difficulty in finding tort liability for damages. $113 \mathrm{Tenn}$. at $350,366-67,83$ S.W. at $662,666-67$. Where a state follows the early cases and does not differeutiate between damage liability and abatement liability, the basic element of comparative utility 
question of compensation for past injuries suffered by plaintiffs. A negative determination would have eliminated further equity questions. But the court found that the smelters constituted a tort, and that triggered the balance of equities on the abateinent question.

The Ducktown abatement question focused on the desirability and consequences of the competing forms of conduct, considering relative hardship between the parties, the balance of comparative social utility between the two competing conducts, and the public interest (whicl usually amounts to the saine thing). ${ }^{56}$ The court declared:

A judgment for damages in this class of cases is a matter of absolute right, where injury is shown. A decree for an injunction is a matter of sound legal discretion, to be granted or withheld as that discretion shall dictate, after a full and careful consideration of every elennent appertaining to the injury. ${ }^{57}$

Citing a series of equity cases in which the utility of defendant's enterprises weighed agamst injunctions, ${ }^{58}$ the court's "careful consideration" began with a question that virtually answered itself:

Shall the complainants be granted, by way of damages, the full measure of relief to which their injuries entitle them or sliall we go further, and grant their request to blot out two great mining and manufacturing enterprises, destroy half of the taxable values of a county, and drive more than 10,000 people from their liones? ${ }^{59}$

(drawn from equity) may result in eliminating the plaintiff's entire cause of action, legal as well as equitable, at this initial stage.

56. This balance is fundamentally a fairness question limited to the two parties involved. It reflects public interest only insofar as the public interest is served by the expectation that equitable determinations will incorporate some sense of proportionality between private litigants.

57. 113 Tenn. at 358,83 S.W. at 664 .

58. Id. at 358-63, 83 S.W. at 664-66.

59. Id. at $366-67,83$ S.W. at 666-67. The court continued:

In order to protect by injunction several sinall tracts of land, aggregating in value less than $\$ 1,000$, we are asked to destroy other property worth nearly $\$ 2,000,000$, and wreck two great mining and manufacturing enterprises, that are engaged in work of very great importance, not only to their owners, but to the State, and to the whole country as well, to depopulate a large town, and deprive thousands of working people of their lomes and livelihood, and scatter them broadcast.

Id. The court then raised questious of political philosophy as well as economic utility:

[W]e are deeply sensible of the truth of the proposition that no man is entitled to any more rights than another on the ground that lie has or owns more property than that other. But in a case of conflicting rights, where neither party can enjoy his own without in some measure restricting the liberty of the other in the use of property, the law must make the best arrangement it can between the contending parties, with a view to preserving to eacls one the largest measure of liberty possible under the circumstances. We see no escape from the conclusion in the present case that the only proper decree is to allow the complainants ... damages, and that the mjunction must be denied to them ... . Id. at $367,83 \mathrm{S.W}$. at 667 .

The fact that it was land that was injured in this case, and that eacli parcel of land is unique in the eyes of equity, see supra note 38 , indicates that this was not just a decision based on the threshold question of adequacy of legal remedies. The saine distinction is nade in the federal courts. See Harrisonville v. W.S. Dickey Clay Co., 289 U.S. 334, 337-39 (1933). The Ducktown 
The Ducktown decision launched a modern trend im private nuisance cases, clearly separating the questions of liability and abatement and requiring defendants whose contimued operations serve public welfare nevertheless to absorb the cost of imjuries imposed on neighbors as a cost of doimg busimess. ${ }^{60}$ It also stands as a paradigm of equitable balancing in determining the abatement of future conduct. In determining that defendants' conduct could contmue despite inevitable future injury to plaintiffs, the court coinpared the parties' private interests and balanced their interests against the court's own view of public welfare. True, a more modern court might well have brought inore public and private values such as health, water quality, and aesthetics into the balance. $^{61}$ Yet the Ducktown court opened the equitable balance to a wide-ranging review of competing values and made its decision based

court further noted that granting plaintiffs' requested injunction "would be practically a confiscation of the property of the defendants for the benefit of the complainants," an appropriation without compensation, whereas plaintiffs would get compensation. 226 Teun. at $367,83 \mathrm{~S}$.W. at 667 . Despite the Ducktown analysis, some of the same defendants were subsequently permanently enjoined for a time in a suit brought by the state of Georgia. The Supreme Court held that interstate pollution presented different equities from those involved in the tort balance in Ducktown. Georgia v. Teunessee Copper Co., 206 U.S. 230 (1907) (bill in equity), decree entered, 237 U.S. 474 and 237 U.S. 678 (1915), modified, 240 U.S. 680 (1916).

60. This approach implements the modern economic efficiency analysis that holds such compensation to be a straightforward, if partial, internalization of external costs. If the requirement of paying such consequent dainages forces a polluting enterprise to shut down, that is an indication that the enterprise was marginal in the first place, subsidized by negative burdens borne by the neighbors' property. Inaccuracies and dislocations also exist in the cost accounting process, of course. On the defendant's side, some awards, like punitive daunages, cannot be characterized as representing actual costs; hence, they may skew economic utility. On the plaintiffs side, it can be noted that many real external cost burdens are nonmonetizable, hence uncompensated. Further, the costs of sequential litigation ensure that plaintiffs do not recover their full losses. Accordingly, the equally classic case of Boomer v. Atlantic Cement Co., 26 N.Y.2d 219, 257 N.E.2d 870, 309 N.Y.S.2d 312 (1970), took a further step toward cost allocation by authorizing courts to assess damage awards for future "permanent" dainages, instead of the Ducktown remedy of repeated tort suits for past damages. The measure of permanent danages in Boomer, however, was irrationally figured on base market values that did not take account of potential appreciation absent the pollution. See Boomer, 55 Misc. 2d 1023, 1025-26, 287 N.Y.S.2d 112, 115 (1967), aff'd, 30 A.D.2d 480, 294 N.Y.S.2d, 452 (1968), rev'd, 26 N.Y.2d 219, 257 N.E.2d 870, 309 N.Y.S.2d 312 (1970).

61. Aside from one passing reference to one plaintiff's wife's cough and headache, 113 Tenn. at $341,83 \mathrm{~S} . \mathrm{W}$. at 660 , the court did not mention health effects to the plaimtiffs, far less to the public. A modern analysis would undoubtedly have weighed such factors as the negative effects on health and property attributable to the smelters (though far removed in time or distance), economic burdens on community services, and ecological damages, which would have resultcd in a far more comprehensive economic assessment of the case. Cf. Keeton \& Morris, Notes on Balancing the Equities, 18 TEx. L. REv. 412, 420 (1940) (commending those courts which have awarded daunages not only to plaintiffs but to others similarly situated). Even the relatively recent Boomer case, however, did not do so, but instead balanced only plaintiffs' individual imjuries, and not similar public mjuries, against a combination of the corporation's property stake and the public's interest in jobs, im determining whether the defendant's conduct should be abated. Booiner v. Atlantic Cement Co., 26 N.Y.2d 219, 226, 257 N.E.2d 870, 873, 309 N.Y.S.2d 312, 318 (1970). See also Spur Industries v. Del Webb Dev. Co., 108 Ariz. 178, 494 P.2d 700 (1972) (conditioning mjunction on the late-coming plaimtiffs payment of relocation dainages to the defendant). 
upon its own subjective judgment of the relative intrinsic values of competing conducts.

Thus, the nonstatutory setting provides an inclusive inodel of equitable discretion in the determination of contending conducts. In traditional common law cases, the court-made rules of conduct which determined damage hability were more or less rigidified in the evolved tort doctrines, while the equitable question of abatement was decided anew in each case. The tort debts owed by one party to the other might be decided by uniformly applicable substantive tort principles, but questions of the life and death of farms and sinelting plants-of who must stop and who inay go on-were left in the flexible hands and heart of equity. ${ }^{62}$ In short, courts have used equity to define and exercise a separate judicial role, grounded upon a rational discretion and working beyond the rigid rules of the law.

\section{Tailoring the Remedies}

Having defined and distinguished the first two kinds of discretionary balancing, the third role of equity becoines anticlimactic, though important. At this point in a lawsuit, law and equity lave determined all the substantive issues, and only the equitable function of implementation remains. If the court had decided in the second stage balance that defendant's conduct may continue, the award of legal dainages for past injuries ends the question of reinedy. In that situation no equitable remedy is necessary unless required to enforce payinent of damages. ${ }^{63}$

When the court determines that defendant's conduct may not continue, on the other hand, a full array of equitable options exists. If defendants agree to abate their activity voluntarily, the court has the option of not issuing any formal equitable remedy at all. This point is important in the statutory setting, as will be seen shortly. ${ }^{64}$ It is taken for granted in the common law setting: an injunction need not issue if

62. See Georgia v. Tennessee Copper Co., 206 U.S. 230, 237-39 (1907) (bill in equity), decree entered, 237 U.S. 474 and 237 U.S. 678 (1915), modified, 240 U.S. 650 (1916).

63. For example, the Ducktown court temporarily enjoined continued operation of the smelters nntil bonds were posted to assure payment of damages. $113 \mathrm{Tenn}$. at $368,83 \mathrm{~S}$.W. at 667 . The injunction threat was used because there was some question of the defendant's financial ability to pay the plaintiffs in the short term; the injunction would issue unless the corporation posted a bond to secure the payment of the judgment. Id. The same kind of "conditional" injunction was issued in Boomer v. Atlantic Cement Co., 26 N.Y.2d 219, 228, 257 N.E.2d 870, 875, 309 N.Y.S.2d 312,319 (1970).

The issuance of the injnnction pending compensation is more than a gratuitous symbol, because it adds the practical leverage of potential economic deprivation (provisional abatement of defendant's enterprise) to hasten payment of the legal damages instead of relegating plaintiff to the position of a creditor holding a chose in action.

64. See infra text accompanying notes 93-108, 166-92. 
the court finds that the abatement decision will be implemented without it, but will usually issue where there is any doubt on the matter. ${ }^{65}$ Between these two extremes lies the declaratory judgment, a remedy slightly more formal and more assertive than the no-injunction option but similarly unenforceable through contempt proceedimgs. Yet in the case of good faith defendants, a declaratory judgment or less may be all that is necessary to implement the court's abatement decision. ${ }^{66}$

The strength and flexibility of injunctions, however, makes them attractive as the remedy of choice in many cases. Equity courts shape mjunctions in multifarious forms: injunctions to lialt an enterprise completely, to shut down a particular component activity, to scale down overall activity by a certain percentage, to halt a specific offensive effect, to abate after a lapse of a specific term if certain performance standards are not achieved-these are but a few. ${ }^{67}$ Injunctions also serve different tactical ends. They can be wielded to drag a rambunctiously recalcitrant defendant into comphance, to tighten the reins on shipshod defendants whose comphance efforts may be sloppy, or merely to add a final reassurmg level of certainty to a good faitl defendant's compliance. In short, "The plastic remedies of the chancery are moulded to the needs of justice." 68

Analytically, the third stage remedy decision imvolves a weighing of the comparative efficacy of available remedies rather than a comparative weighing of interests. Simce the tailoring of remedies involves choices between options, shaped by the court's judgment about the

65. The only evident exceptions would be where injunctions would be unenforceable and futile. See supra note 28.

66. This is an important point that reappears later in Hecht Co. v. Bowles, 321 U.S. 321 (1944), discussed at length infra in text accompanying notes 73-112. Thus, for instance, a major point of Michigan law-the prevention of multiple subdivision-lot canal access to inland lakeswas litigated as a declaratory judgment, out of recognition that once rights were declared, the parties would comply. Thompson v. Enz, 379 Mich. 667, 674 passim, 154 N.W.2d 473, 477 passim (1967). See also Colorado v. First Nat'l Bank, 540 F.2d 497 (10th Cir. 1976); Philadelphia Citizens in Action v. Schweiker, 527 F. Supp. 182 (E.D. Pa. 1981). It should be noted furthcr that declaratory judgments are not clearly categorizable as equitable or legal remedies, see Beacon Theaters v. Westover, 359 U.S. 500, 506-07 (1959) (treating them as purely legal remedies), but derive from statute when part of the equity jurisdiction, and take on the quality, chameleon-like, of the cause of action on which they are based. See Perez v. Ledesma, 401 U.S. 82, 93 (1971) (Brennan, J., concurring in part and dissenting in part); Federal Declaratory Judgment Act, 28 U.S.C. $\$ \S$ 2201-2202 (1976 \& Supp. III 1979); H. McClintock, HANDBoOK OF THE PrunCIPLES OF EQUTTY \& 51, at 121 (2d ed. 1948); 1 J. POMEROY, supra note 33, at 228-29.

67. See 5 J. PoMeroy, supra note 33, \& 1948 (2d ed. 1919).

68. Foreman v. Foreman, 251 N.Y. 237, 238, 167 N.E. 428, 429 (1929) (Cardozo, J.) (a case based upon equity's constructive trust doctrine). Thus Judge Jasen, dissenting in Boomer, argucd that an appropriate remedy in light of the public interest in clean air was to encourage innovative technology through an abatement ijjunction effective after 18 months. Boomer v. Atlantic Cement Co., 26 N.Y.2d 219, 231, 257 N.E.2d 870, 877, 309 N.Y.S.2d 312, 322 (1970) (Jasen, J., dissenting). 
practicalities and relative effectiveness of those options, it does no violence to the term "balance of equities" to include this latter balance within it.

Recognizing that courts sitting in equity do compare the available alternatives in deciding what remedy to issue to effectuate the prior decision on the merits clarifies the fact that the remedy choice is a separate decision. Separating the role of equity into its three components also establishes a useful analytical framework for the modern statutory injunction.

\section{III}

\section{Balancing the Equities In the Statutory Context}

The exercise of equitable jurisdiction, particularly the availability of injunctions, lias increased over the years. The anachronistic requirement of a property interest in order to invoke equity ${ }^{69}$ has been scrapped of nccessity, and other impediments liave been reinoved. ${ }^{70}$ Despite regular protestations to the contrary, ${ }^{71}$ the status of the injunction as an extraordinary reinedy has evaporated. The injunction has becoine a common, widely used judicial remedy precisely because of its ability to fine-tune the requirements of private conduct in a complex, modern society. Its devclopinent parallels the expansion of cases, especially in civil rights and other constitutional areas, where damage reine-

69. In re Debs, 158 U.S. 564 (1895). See O. Fiss, The CiviL Rights Inunnction 41 (1978). The anachronistic nature of the property requirement for issuance of injunctions was repeatedly demonstrated, as in the Debs case where the government had to claim a property interest in the U.S. mails in order to request an mjunction against the labor organizer's putatively dangerous utterings.

The arguments for maintaining the exceptional character of the injunction find their basis in particular pohtical pragmatics-for example, in the 1930's and 1940's in an aversion to the broad availability of labor injunctions against collective employee actions, see F. FRANKFURTER \& N. GREENE, THE LABOR INJUNCTION (1930) (making an extensive argument for restricted use of such mjunctions), and more recently, in a general opposition to the alleged social activisin of courts. The controversies arising in the aftermath of Brown v. Board of Education, 347 U.S. 483 (1954), and the civil rights housing cases, for example, have been directed more to the process of judicially ordered remedies than to the courts' declarations of the law involved.

70. Among the other lowered barriers to equitable jurisdiction are the decline of the irreparability requirement and the willingness to enjoin what arguably nay be criminal activity. See O. Fiss, supra note 69, at ch. IlI; 7 J. MOORE, supra note 2, \ 65.04(1).

71. E.g., United States v. Philadelphia, 644 F.2d 187, 192 (3d Cir. 1980); Kaynard v. Mego Corp., 633 F.2d 1026, 1033 (2d Cir. 1980); Continental Group, Inc. v. Amoco Chems., 614 F.2d 351, 356 (3d Cir. 1979); Carter v. Taylor, 409 F. Supp. 1162, 1164 (E.D. Tenn. 1975) (citing Frankfurter, J., in Railroad Comm'n v. Pullman Co., 312 U.S. 496, 500-01 (1941)); Drummond Citizens Ins. Co. v. Sergeant, 266 Ark. 611, - 588 S.W.2d 419, 424 (1979); Agricultural Labor Relations Bd. v. Ruline Nursery Co., 115 Cal. App. 3d 1005, 1015, 171 Cal. Rptr. 793, 797 (1981); Waterbury Teachers Assoc. v. Civil Service Comm'n, 178 Conn. 573, 576, 424 A.2d 271, 273 (1979); Delano v. Collins, 49 Ill. App. 3d 791, 795, 364 N.E.2d 716, 720 (1977). 
dies are insufficient or miss the point. ${ }^{72}$

Yet in a time of unparalleled statutory proliferation, the flourishing of the equity jurisdiction, especially the wide use of injunctions, presents a paradox. The opportunities for einploying equitable discretion have increased over recent years. In part this is a function of increased common law hitigation in the environmental and consuiner law areas; in part it is a function of constitutional litigation; in largest part, however, it derives fron the growth of the regulatory state. In the first two areas-common law and constitutional cases-discretion has always been and reinains at the heart of equity jurisdiction. But when Congress and state legislatures create a succession of declaratory statutes administered by executive agencies, a paradox appears: the opportunities for exercise of equity jurisdiction have inultiplied at the same time that the scope of equitable discretion seems to have been truncated.

The existence of statutes inevitably inakes as much a difference for equity jurisprudence as it does for the common law. Statutes codify particular standards of conduct and declare public policy. Just as it does not seem surprismg that common law rules, such as those pertaining to unfair competition, can be superseded by statutes like the antitrust acts, it should not be surprising that the application of equitable principles can be fundamentally changed by statute.

To what extent, however, do statutes change equitable discretion? Do they merely add a clear element of public policy to the balance of equities, leaving all options open for the court's exercise of discretion in the three traditional stages of balance, or do they eliminate discretion in one or more of the three areas? The resolution of this crucial issue depends $m$ part on the functional distinctions we have discerned in traditional equitable jurisprudence; it inust also incorporate a careful analysis of one particular New Deal case that dominates modern discussions of statutory violations and equitable discretion.

\section{A. The Hecht Case}

A inuch-cited but little-analyzed 1944 price control case, ${ }^{73}$ Hecht Co. v. Bowles, ${ }^{74}$ dominates the debate on the effect of statutes on the equity powers of courts. In Hecht the Supreine Court resoundingly de-

72. O. Fiss, supra note 69, at 4-6; see also id. chs. III, IV; Developments, supra note 16, at 998-1001.

73. Of the two published analyses of the case, only one briefly discussed the equitable principles of injunctive necessity. 28 MARQ. L. REv. 128, 130 (1944). The other gave more attention to the political consequences of Hech's limitation on overzealous bureaucrats than to equitable doctrine. 32 GEO. L.J. 449, 452 (1944). Fiss' discussion of Hecht focuses on the fact that the mjunction remedy seemed mandatory on the face of the statute. O. Fiss, supra note 2, at 98-100.

74. 321 U.S. 321 (1944). 
nied an injunction in the face of clear statutory violations. Upon uncritical reading, therefore, Hecht is often thought to imply a judicial power to permit statutory noncoinphiance. ${ }^{75}$ But a closer reading of Hecht, in the special setting in which the case arose, defines a inuch niore careful line between courts and legislatures. The Hecht case was based upon three important features: a clearly established record of past statutory violations, an alınost equally clear showing that violations would not recur, and a statute that seemed to dictate injunctive rehef on the basis of past violations alone without regard to present coinphiance.

The existence of overcharging violations prohibited by the wartime Einergency Price Control $\mathrm{Act}^{76}$ was not really at issue in Hecht. Between May and October of 1942 the Hecht Coinpany departinent stores had clearly sold consunier goods at prices which, in hundreds of instances, violated the Act. Hecht made no serious atteinpt to deny the past violations. ${ }^{77}$ Instead, the coinpany argued that the violations were attributable to the understandable difficulties encountered in the initial application of a coniplex piece of economic regulation to a large and highly diversified commercial enterprise. The violations were not the result of bad faith, they argued; the overcharges would be returned where possible and otherwise given to charity. More important for the Court in Hecht-and niore significant for the present argument-the defendant was determined to coinply with the law in the future and had taken practical measures to ensure coinphiance. Hecht had corrected sales procedures, trained its personnel, and updated inventory procedures. ${ }^{78}$ The trial court had found that there was no substantial likelihood that violations would recur. ${ }^{79}$ This was the fundaunental

75. See, e.g., Winner, supra note 35 , at 506 (concluding that "[c]ourts . . usually balance the equities before issuing an injunction . . . for violation of environmental statutes."). See also Lemon v. Kurtzman, 411 U.S. 192 (1972); FTC v. Weyerhaeuser Co., 665 F.2d 1072, 1084 (D.C. Cir. 1981); Parkview Heights Corp. v. City of Blackjack, 605 F.2d 1033, 1036 (8th Cir. 1979); Barcelo v. Brown, 478 F. Supp. 646, 706 (D.P.R. 1979), affd in part and vacated in part, 643 F.2d 835 (1st Cir.), cert. granted sub nom. Weinberger v. Romero-Barcelo, 102 S. Ct. 88 (1981), discussed infra in text accoinpanying notes 243-63.

76. Emergency Price Control Act of 1942, ch. 26, 56 Stat. 23 (terminated 1947).

77. The Hecht Company formally continued to deny the violations, apparently on estoppel grounds, Brown v. Hecht Co., 137 F.2d 689, 690 (D.C. Cir. 1943), rev'd, 321 U.S. 321 (1944). But the evidence was clear that the store was in disorder in terms of compliance; spotchecks consistently turned up violations, seven of which were made the formal basis of the complaint. Id. at 691.

78. Id. at 690 .

79. 321 U.S. at 326 (citing district court opinion, 49 F. Supp. at 532). The Office of Price Administration (OPA) was sure that further violations would inevitably occur. Interview with the late Professor Fleming James, Jr., former OPA assistant counsel (July 15, 1981). Professor James had argued Hecht in the lower courts. But the Court's position is consistent even if it accepted the fact that soine further violations were inevitable given the statute's complexity. An injunction would not deter involuntary violations, and the courts were unlikely to punish such violatious in 
feature of the case; it probably was the reason that the Court granted certiorari. ${ }^{80}$ Relying on that finding, the district court had declined to issue an injunction which "would have 'no effect by way of insuring better coinpliance in the future,' and would be 'unjust' to petitioner and not in the public interest." "81 The court of appeals, however, had insisted on an injunction. ${ }^{82}$

The Hecht facts also included a special statutory twist that is important to our equity analysis. Section 205 of the Emergency Price Control Act appeared to require that a court issue an imjunction whenever it found a violation of the Act: "[U]pon a showing by the Administrator that such person has engaged or is about to engage in any such acts or practices a permanent or temporary injunction, restraining order, or other order shall be granted without bond."83

For the Office of Price Administration (OPA), Hecht was a test case. Its attorneys strenuously argued that injunctions were mandatory even in cases of past violations, and insisted on issuance of an injunction against future violations. Mandatory mjunctions would both simplify enforcement procedures under the Act and establish a vivid deterrent for thousands of regulated retail establishments around the country which, whether innocently or not, were out of compliance with the Act. ${ }^{84}$ The OPA attorneys argued that botli the statutory language and the legislative history showed that Congress intended injunctions to be mandatory. ${ }^{85}$ In short, the OPA asserted a sweeping statutory override of the courts' traditional equitable discretion.

The Supreme Court unanimously rejected the OPA's argument. ${ }^{86}$

contempt proceedings. In these circumstances, an injunction was neither effective nor desirable in achieving compliance. This seems to be an appropriate form of discretionary balancing.

80. There was widespread political opinion in the capital in the years prior to passage of the Administrative Procedures Act, ch. 324, 60 Stat. 237 (1946) (current version at 5 U.S.C. $\$ \$ 551-559$ (1976 \& Supp. III 1979)), that rampant bureaucracy had been given too many powers, which courts should be able to curb. See C. Rembar, THE LAW of the LAND: THE Evolution of OUR LEgAL SYSTEM 311-13 (1980).

81. 321 U.S. at 326.

82. 137 F.2d at 689.

83. Emergeucy Price Control Act of 1942, ch. 26, $\$ 205$ (a), 56 Stat. 23, 33 (terminated 1947) (emphasis added).

84. "We wanted to put the fear of the Lord into them, in the sense that we were serious about enforcement," said the OPA's former associate general counsel recently. "There were thousands of stores out of compliance, and Hecht's was the Washingtou equivalent of Macy's" [i.e., prosecution of a well-known major store would have a salutary deterrent effect]. He also remembered that "we had to go ahead on Hecht's because everyone in the business knew we had mvestigated and found violations." Telephone interview with Professor Thoinas 1. Einerson, former OPA associate general counsel (July 18, 1981).

85. "We had written the Senate committee report ourselves. It had been drafted by David Ginsberg, who was counsel to the OPA." Id.

86. Justice Roberts concurred without opinion; Justice Frankfurter concurred with the sinple ambiguous statement that " $\$ 205(a)$. . . does not cluange the historic conditions for the exer- 
Backed by "several hundred years of history," the Court declared: The essence of equity jurisdiction has been the power of the Chancellor to do equity and to mould each decree to the necessities of the particular case. Flexibility rather than rigidity has distinguished it. The quahties of mercy and practicality have made equity the instrument for nice adjustment and reconciliation between the public interest and private needs as well as between competing private claims. We do not beheve that such a major departure from that long tradition as is here proposed should be hightly implied. ${ }^{87}$

This passage has been cited again and again when courts wish to invoke the special heritage and character of equity and to establish the proposition that equitable discretion is not eliminated by the pronnulgation of a statute. ${ }^{88}$

The hortatory language of the Hecht opinion, set in the impassioned context of midcentury contests between courts and agencies, ${ }^{89}$ has permitted it to entertain sweeping interpretations in many subsequent cases. ${ }^{90}$ When read in light of the three stage analysis of traditional equity, lowever, the actual holding of the Hecht case defines a more limited role for equitable discretion in the statutory context.

In fact, Hecht raised no question at all with respect to the first two stages of equitable balancing. The case contained no substantial issues at the threshold stage. As to the second type of equitable balancingthe determination of contending conduct-one searches in vain for any indication in the opinion that courts could override a congressional determination of which conduct was proscribed and which permitted. Nowhere did the Court even hint that the dispositive nature of the congressional definition of price control violations could be judicially questioned. ${ }^{91}$ Indeed, the factual premise underlying the Court's entire discussion was that Hecht's past violations would not continue.

cise by courts of equity of their power to issue injunctions . . ." 321 U.S. at 331 (Frankfurter, J., concurring). Whether Justice Frankfurter was emphasizing judicial power not to issue injunctions in any and all circumstances is unclear, although just two years later, in NLRB v. Cheney Lumber Co., 327 U.S. 385, 388 (1946), he made clear that a court could not substitute its own equitable balancing for an agency's decision where the agency had been given a clear grant of discretion. As Chief Justice Stone's concurring opinion poimted out, however, the latter case is best viewed as turning on issues of scope of review rather than scope of equitable discretion. 327 U.S. at 389-90 (Stone, C.J., concurring). In the Steelworkers case, Justice Frankfurter clearly stated his view that Congress could eliminate a court's discretion to issue an injunction. United Steelworkers v. Umited States, 361 U.S. 39, 50-51, 54, 56, 58-59 (1959), discussed infra in text accompanying notes 198-219.

87. 321 U.S. at $329-30$.

88. See cases cited supra note 75.

89. As to the political background, see 32 GEO. L.J. 449, 452 (1944).

90. See supra note 75.

91. "No one had argued that a court could override a violation; if they had, the Supreine Court would not have taken long with thein . . . Emerson interview, supra note 84. 
The Hecht Court's deference to congressional definitions of prohibited conduct certainly comports with a legal system composed of both court-made and legislated rules. The most common function of statutes is to make substantive rules of conduct that otherwise are made, if at all, by law and equity acting together. To argue that courts possess the power, case by case, to suspend statutory rules of conduct, often $\mathrm{m}$ areas in which no prior common law rules exist, is to argue for an unusual expansion of judicial power that would have surprised both King and Chancellor. Rather, like the canon that statutes in derogation of common law will be construed narrowly (which does not mean that statutes cannot derogate common law), Hecht declared that statutes in derogation of equitable discretion will also be strictly construed. ${ }^{92}$ Strict construction of statutes is a very different proposition from judicial overrides of statutory rules of conduct.

Hecht's major focus was on the third area of equitable discretion, the choice of remedy to implement and accommodate the congressional rule. The district court had fashioned a judicial remedy that consisted of no remedy: having specifically found that compliance with the statute had already been achieved and that future violations were unlikely, it dismissed the complamt. The question on certiorari was whether the statute allowed the district court to do this ${ }^{93}$ and, if so, whether dismissal was a proper resolution for this case or an abuse of the trial court's discretion. The latter poimt was remanded, ${ }^{94}$ so the authority question was the only one decided.

In part, Hecht's determination of a qualified judicial right to tailor remedies rested upon statutory interpretation. The Court determimed at the outset that the statutory language did not clearly mandate the issuance of an injunction when a violation had been proved. Section 205(a) said the court "shall" grant a "permanent or teinporary imjunction, restramimg order, or other order," some cases this could mean as little as an order mamtaining jurisdiction over the case pending compliance. ${ }^{96}$ "Thus it seems that $\S 205$ (a)

92. 321 U.S. at 330 .

93. Note the approach of another commentator who participated in the controversy: "Congress could punish the violation as a crime; obviously Congress could make it an occasion for an injunction. Some states had done away with chanccry altogether. Could not the nation-especially im wartime-modify chancery's operation?" C. REMBAR, supra note 80, at 313.

94. 321 U.S. at 330-31.

95. Emergency Price Control Act of 1942, ch. 26, \& 205(a), 56 Stat. 23, 33 (termimated 1947) (emphasis added).

96. 321 U.S. at 328-29 (adopting the approach of Judge Grover's dissent below, 137 F.2d at 696). This imterpretation, and a related construction limiting $\S 205(a)$ to the status of a grant of jurisdiction to issue injunctions without bonds, found some support in the legislative history. 321 U.S. at 328. Further, it is clear that $\$ 205$ (a) did not require the OPA to request an injunction whenever a violation was found. It would have been surprising, in fact, if this had been the case, 
falls short of making mandatory the issuance of an injunction inerely because the Administrator asks for it."97 Given the ainbiguity of the statute and its legislative history, ${ }^{98}$ the Court recognized a limitation on equitable discretion but declined to construe it as a broad override. Courts are not free to fashion their own substantive rules; rather "their discretion . . . must be exercised in light of the large objectives of the Act."99 Thus, the Hecht Court chose the statutory interpretation "which affords a full opportunity to treat enforcement proceedings under this [Act] in accordance with . . . traditional practices, as conditioned by the necessities of the public interest which Congress has sought to protect." 100

In Hecht the necessity of statutory compliance wholly "conditioned" equity's choice of remedy. The Court repeatedly stressed that comphance with the congressional rule of conduct was mandatory, and equity served that compliance requirement. A court cannot exercise its discretion so as to reduce "the large objectives of the Act" to inerely one factor in an independent balance of equities on compliance. "[The] courts are given jurisdiction to issue whatever order to enforce compliance is proper in the circumstances of each particular case." 101 An mjunction need not issue if soine other order "would be as practically effective as the issuance of an injunction." 102 In the case of Hecht's price control violations, the injunction was properly denied be-

and it appears that the OPA did not request injunctions for every violation encountered. Note, The Statutory Injunction as an Enforcement Weapon of Federal Agencies, 57 YALE L.J. 1023, 1027 (1948). Thus, the Court might well have concluded that the statute implied an intermediary agency decision to request an injunction from the courts, and in the Hecht Coinpany's circumstances the OPA's decision to request an injunction was an act reviewable for abuse of discretion regarding the congressional price control purposes. In that light, the Court's decision might stand for a judgment that the OPA's request had no rational basis, hence was arbitrary and capricious or an abuse of discretion, and the section did not apply.

97. 321 U.S. at 328 . Recogmition of the variety of orders available is another affirmation of the traditional scope of discretion at the third stage of litigation.

98. The Court found that the Senate Report could be argued either way, 321 U.S. at 328, which refiects rather badly on the OPA's efforts at writing legislative history. See supra note 85.

99. 321 U.S. at 331. This distinction had been inade under other statutes in a series of lower court cases which the Court did not deen necessary to cite, although they had been briefed. In SEC v. Otis \& Co., 18 F. Supp. 100 (S.D. Ohio 1940), for example, an injunction would not issue where future violations had not been shown to be likely. In Walling v. Peavy-Wilson Lunnber Co., 49 F. Supp. 846 (W.D. La. 1943), an injunction issued, even though violations had ceased shortly prior to the action, apparently because the defendants' past conduct did not warrant faith in their continued statutory compliance. See infra text accounpanying notes 148-49.

100. 321 U.S. at 330.

101. Id. at 329, (einphasis added) (citing the Price Control Act's S. REP. No. 931, 77th Cong., 2d Sess. 10 (1942)). It is not unusual that this might result in a variety of different decrees in enforcemcnt actions under the same statute. "[An equity] decree in one case will seldoin be an exact counterpart of a decree in another." TVA v. Hill, 437 U.S. 153, 213 (1978) (Rehnquist, J., dissenting).

102. 321 U.S. at 328 . The alternative discussed-an order retaining district court jurisdic- 
cause it would do nothing to assure better compliance. ${ }^{103}$ In sucl1 circumstances, deterrence was not at issue; the only function of an mjunction would be to punisli Heclit for past misdeeds, a task that equity tries to avoid. ${ }^{104}$

The Hecht Court held that "tlie cessation of violations, whether before or after the institution of a suit by the Administrator, is no bar to the issuance of an injunction ...."105 The touchstone was the likelihood of future violations. When they were unlikely to occur, no injunction was necessary. The Court noted that "[a] grant of jurisdiction to issue injunctions is of course not a requirement that they be issued." 106 "[W]e do not think that under all circumstances the court must issue the mjunction or other order which the Administrator seeks." 107 Still, the room thus provided for the exercise of equitable discretion was firmly grounded upon the assurance of future comphance with the statute. ${ }^{108}$

Hecht also addressed the possibility that statutes might impose some limitations on imitial thresliold equitable determinations, "[f]or the standards of the public interest, not the requirements of private litigation, measure the propriety and need for injunctive relief in these cases."109 Although the Court used this language to articulate the cooperative nature of courts and agencies in implementing the substantive policies of statutes, it has subsequently been taken to support departures in the statutory context frow the traditionally required thresliold showings. ${ }^{110}$

Nor was this the only limitation of judicial discretion recognized in Hecht. The decision also contains implicit recognition of the fact that Congress could have removed all discretion from price control

tion-was thus based on the finding of voluntary compliance whicl obviated the necessity for an imjunction.

The statutory phrase "or other order" (which Hecht construed as manifesting the traditional panoply of available equitable remedy choices) could perhaps also be stretched to include the order of dismissal issued by the trial court in that case. See supra note 96 . Or, if some affirmative order were required by $\$ 205$ (a) when a past violation was proved, the court could achieve the same result by deciding that the OPA abused its discretion in bringing the complamt in the first place, thereby sidestepping the section's purported mandate.

103. 321 U.S. at 326.

104. Id. at 329.

105. Id. at 327. See United States v. W.T. Grant, 345 U.S. 629, 633 (1953).

106. 321 U.S. at 329 (emphasis omitted).

107. Id. at 328 .

108. Id. at $326,329$.

109. Id. at 331. "These cases" referred to the cases cited in a prior paragraph discussing various situations where courts were involved with regulatory statutes and agencies, as in United States v. Morgan, 307 U.S. 183, 191 (1939).

110. See cases cited infra notes 157-65. 
cases, even if it was held not to have done so. ${ }^{11}$ Thus, Hecht clearly did not hold that Congress lacks the power to reduce the scope of the courts' equitable jurisdiction. ${ }^{12}$

Far from seeuring an unfettered equitable discretion, Hecht articulated a limited role for equity. Courts are to be guided by public policy in interpreting the traditional threshold tests, constricted in all cases by Congress' substantive rules of conduct, and potentially constrained even as to choice of remedy. Accordingly, Hecht, the leading case regarding the relationship between equity and statutes, established two major poimts. First, unless Congress explicitly demands that a particular remedy be apphed to all violations of a statute, the courts retaim equitable discretion in choosing a remedy to enforce the statute. So stated, this principle will be rarely contested, and, though important, it is not very interesting. Second, when a statutory violation is proved, equitable discretion is to be exercised as necessary to achieve statutory coinphance. Hecht leaves no room for the proposition that the traditional balance of equities applicable to common law litigation remains unfettered so as to allow the courts to permit continued statutory noncompliance. For our purposes, this second principle is the more interesting. Unfortunately, in Hecht and the cases that cite Hecht, it was lost $\mathrm{m}$ the brouhaha accompanying the first.

\section{B. Reading Hecht}

The Hecht Court's panegyric to equitable discretion, when considered without regard to the case's factual and procedural setting, has been responsible for a large measure of the subsequent confusion char-

111. 321 U.S. at 329-30 ("[I]f Congress had intended to make such a drastic departure from the traditions of equity practice, an unequivocal statement of its purpose would have been made.").

112. It is difficult to argue that legislatures could not, if they desired to do so and did so explicitly and unequivocally, take over the entire field of a court's equitable discretion in all three areas of balancing of equities, at least in a statute-based action. A statute could say: "A person who has suffered imjury as defined in this statute unay maintain an action without regard to available affirmative defenses," eliminating equity's threshold discretion; it could provide that once the elements of a violation have been proved, a court must see to it that the defendants' conduct cease (or alternatively that damages only may be assessed); and finally the statute could legislate a precise remedy, e.g., "a permanent injunction immediately abating the activity slall issue in all such cases," or alternatively that only a damages remedy will issue. It may well be, lowever, that Congress could not do so with regard to the adjudication of constitutional rights or vested common law rights, at least as to issues of permanent equitable relief. As to administrative law actions, the courts' article III jurisdiction and the adjudicatory rights of the sixth and seventh amendments stand in a different posture when they relate to adjudicable issues which existed in 1789 and when they relate to new statutory schemes which may be consigned in part or in totality to an administrative process created for the purpose. See, e.g., Atlas Roofing Co. v. OSHA, 430 U.S. 442 (1977). Other limitations, even affecting constitutional claims, can be legislated as to interlocutory relief, if permanent relief is thereafter available. Yakus v. United States, 321 U.S. $414,439-42$ (1944). 
acterizing discussions of the relationship between equitable jurisdiction and statutes. Many decisions simply overlook Hecht's fundamental insistence on statutory compliance.

Although many examples of the phenomenon are available, ${ }^{113}$ one notable recent opimion that used Hecht's broad language without recognizing its msistence on compliance is Justice Rehnquist's dissent in TVA v. Hill, ${ }^{114}$ the Tellico Dam "snail darter" case, discussed further in Part IV of this Article. ${ }^{15}$ At this point it will be helpful to contrast Justice Rehnquist's analysis of the equitable discretion question with the analysis in the Hecht opinion, the case on which he placed principal reliance.

Quoting Hecht, Justice Rehnquist's dissent in Hill noted that " 'a grant of jurisdiction to issue compliance orders hardly suggests an absolute duty to do so under any and all circumstances . . . . [T]he district court possessed discretion to refuse injunctive relief even though it had found a violation of the Act . . .."116 So far, this goes no further than Hecht, where the injunction was denied on proof of future statutory compliance. The dissent in Hill, however, contmued by saying that "the only remaining question is whether this discretion was abused in denying . . . an mjunction." 117 This formulation of the issue missed Hecht's fundanental requirement of statutory compliance. It attempted to assert that a district court can refuse to enjoin statutory violations, not because statutory compliance was assured, but rather because in the district judge's personal opinion, the statutory "imterest on one side of the balance was more than outweighed by other equally significant factors ...., including significant public and social harms that would flow from such relief and . . . the demonstrated good faith of petitioner." 118

This is a major leap. Reading Hecht accurately to say that equitable discretion is not completely eliminated by a statute absent an exphicit congressional declaration, Justice Rehnquist concluded that the court therefore had an unlimited ability to override the statute. If the

113. See supra note 75 .

114. 437 U.S. 153, 211 (1978).

115. See infra text accompanying notes 298-304.

116. 437 U.S. at 212,213 (quoting Hecht, 321 U.S. at 329) (emphasis omitted). The same thing can be said of Justice Rehnquist as was said of Harvard's Professor Joseph H. Beale (18611945): that it is possible to refute his arguments, but never if you let him state the question. A.J. Casner \& W.B. Leach, Cases and Materials on Property 83 n.3 (2d ed. 1968). See, e.g., Industrial Uvion Dep't v. American Petroleum Inst., 448 U.S. 607, 675 (1980) (Rehnquist, J., concurring); Vermont Yankee Nuclear Power Corp. v. Natural Resources Defense Council, Inc., 435 U.S. 518, 538 (1978); Arnett v. Kennedy, 416 U.S. 134, 147-48 (1974) (plurality opmion); Florida E. Coast Ry. v. ICC, 410 U.S. 224 (1973).

117. 437 U.S. at 212.

118. Id. at 213. 
statute does not completely restrict the equity court's discretion, it does not restrict it at all. It is not clear either logically or from the text of Hecht that the case can carry this added burden. The OPA had argued in Hecht that the statute had removed equitable discretion at all three traditional stages-threshold access to the courts, the determination of conduct, and the tailoring of remedies. According to Justice Rehnquist's interpretation, the Court's rejection of the OPA claim left the equity jurisdiction at the other extreme, unhindered by the statute in any of these three aspects.

Courts that cite Hecht for the existence of a power to refuse injunctive relief without noting Hecht's insistence on statutory compliance make the classic mistake of confusing the choice of remedy with the abatement decision itself. ${ }^{119}$ Hecht's assertions of equitable discretion in the choice of remedy were all addressed to the effectuation of the congressional command. The Supreme Court presumed that ConHill:

119. This was the basis of the Rehnquist dissent. The point, however, had been argued in

C.J. BURGER: Do you suggest that any of the legislation passed here has abrogated the normal equity function of a United States District Judge in granting an injunction, the very extraordinary rehef that is sought here ... are you suggesting that he should not function as he does with any other application for an injunction?

COUNSEL FOR RESPONDENTS: We do not advocate the stripping of this Court or any court of the equitable powers . . that is to say, the equity courts liave the full panoply of powers required to enforce the laws of Congress.

J. REHNQUIST: But Hecht against Bowles says you don't get an injunction automatically for a statutory violation.

COUNSEL: That's correct, Your Honor. And we do not insist on an injunction. If petitioner agreed to obey the law voluntarily, as the Hecht Corporation did in that case, or as the Mosinee Paper Corporation [sic] agreed [to dol-

C.J. BURGER: Then you don't need an injunction?

COUNSEL: That's precisely right.

C.J. BURGER: It's academic.

COUNSEL: And the law would be complied with . . . .

C.J. BURGER: But the question that I'm putting to you is, should not the District Court, confronted with an application to enjoin the operation of a dam in which ... $\$ 110$ million has been invested, exercise the ordinary functions of an equity judge weighing and balancing the equities?

COUNSEL: Let me-yes, Your Honor, it seens to me that the Court does have equitable discretion-

C.J. BURGER: And that includes the equitable discretion not to enforce the statute?

COUNSEL: No, Your Honor, it does not.

C.J. BURGER: You think it does not. . . .

J. REHNQUIST: I don't agree with you, Mr. Plater. Because you have a long history of equitable adjudication where, for instance, a building is built over a lot line, and there has been a contest throughout, but the chancellor doesn't reach a decision until the building is finally built. And he inay say, applying the common law, which has the same sanction to him as the legislative laws passed by Congress, I will give you damages, I will not give you an injunction. Now why isn't this an appropriate case for that sort of an adjudication?

COUNSEL: Several reasons: number one is, [that here] damages, of course, is not a reinedy. Once a species is rendered extinct, as Congress said, it is extinct forever.

Secondly, of course, that would be involving private parties under the common law. This Court has repeatedly said that in cases which involve a Congressional statute . . . 
gress' directive must be obeyed without regard to the utility or public interest involved in the defendant's conduct. It is difficult even to imagine the Hecht trial court balancing the desirability of price control against the value of unfettered marketing practices to the public and to the defendant (as Justice Rehnquist's dissent in Hill would seein to advise). ${ }^{120}$ The Hecht Court thus accepted-indeed, based its holding on-a restriction of equitable discretion to the limited task of determining the necessity of various reinedies in effectuating congressional rules of conduct.

\section{Hecht's Antecedents}

Although the Supreine Court had not previously addressed a case quite like Hecht, the various elements of that decision had been developed in prior cases. The fact that the Hecht Court cited almost none of these cases inay have indicated that it regarded its conclusions as selfevident.

One fundainental characteristic of the evolving law to that time was the recognition that statutes made a difference to the exercise of the courts' equitable role. Hecht's recogmition that equitable discretion is determined by "the standards of the public interest, not the requireinents of private litigation" 121 followed a long series of statute-based cases in the Supreme Court and in lower appellate courts holding that injunctions for statutory violations could be issued without traditional threshold showings. Equitable reinedies issued, for example, despite

the principle which guides the Court in the exercise of its discretion is enforcing the law, which has not been set up by common law but by statute.

J. REHNQUIST: It's coinpletely opposite in Hecht against Bowles.

COUNSEL: No, Your Honor; we are not arguing that an injunction must be issued. Under the Hecht case.... .

J. REHNQUIST: That is, if there were voluntary compliance, and an imjunction wouldn't be necessary. And that was Hecht v. Bowles.

COUNSEL: Yes, Your Honor. The Hecht case said if compliance with Congressional statute would otherwise be achieved, the court of course need not issue an injunction. We would be pleased if an imjunction would not have been necessary in this case .....

Transcript of Oral Argument at 51-54, Hill (Apr. 18, 1978).

The equity argument had been briefed and argued extensively in the court of appeals. In the Supreme Court, however, the government decided that it did not want to argue in favor of equitable statutory overrides. Accordingly, the issue was not mentioned in the petitioner's brief. It was argued in a long footnote in Respondent's Brief at $45 \mathrm{n} .40$, and in an amicus brief in favor of statutory overrides, Brief by the Pacific Legal Foundation at 5-11. Incidentally, the actual expenditure on the dam and associated levees at the time of the Supreme Court hearing was slightly more than $\$ 20$ million. See infra note 300 .

120. Suppose, for example, that the district judge decided that important consumer goods would not be available if the price control statute were applied to hold down prices and took on the job of exempting such goods from the Act. This would seem to raise serious questions of separation of powers as well as questions of practicality. See infra text accompanying notes 30519.

121. 32 I U.S. at 331. 
allegations that the plaintiff government had failed to show irreparable injury ${ }^{122}$ or inadequate remedy at law, ${ }^{123}$ that the government was not doing equity, ${ }^{124}$ and that the government was otherwise estopped. ${ }^{125}$

Prior cases had also inade it clear that statutory declarations of public policy would limit the court's equitable discretion witl regard to substantive rules of conduct. The Supreme Court considered the issue in 1937 in the Virginian Railway case. ${ }^{126}$ A lower court liad decreed that the Railway Labor Act ${ }^{127}$ required the Virginian Railway to negotiate with a union. ${ }^{128}$ The company resisted the order on the ground that equity traditionally would not compel such action. The Supreme Court, after explaining the statutory requirements, held that the company liad to coinply:

The fact that Congress has indicated its purpose to inake negotiations mandatory is in itself a declaration of public interest and policy which should be persuasive in inducing courts to give relief. It is for [such] reasons that courts, which traditionally lave refused to compel performance of a contract to submit to arbitration, . . . enforce statutes commanding performance of arbitration agreements. ${ }^{129}$

There was one case that nay have given the Hecht Court pause. United States v. City \& County of San Francisco, ${ }^{130}$ which had been strongly argued to the Supreine Court and below in Hecht, ${ }^{131}$ seeined to declare an absolute deference to Congress in fashioning equitable remedies. At issue in San Francisco was a congressional water grant ${ }^{132}$ that explicitly prohibited the city from selling any power to a private company for resale. The Court determined that the city had violated

122. Fleming v. Salem Box Co., 38 F. Supp. 997, 998 (D. Or. 1940).

123. Virginian Ry. Co. v. System Federation No. 40, 300 U.S. 515, 551-52 (1937); SEC v. Jones, 85 F.2d 17, 17 (2d Cir.) (per curiam), cert. denied, 299 U.S. 581 (1936).

124. United States v. Trinidad Coal \& Coking Co., 137 U.S. 160, 170, 171 (1890) (bill in equity not defeated when government refused to reimburse individuals for money paid under patents government sought; a hint that government knew of fraudulent coal land sales was also no bar to the injunction).

125. United States v. City \& County of San Francisco, 310 U.S. 16, 31, 32 (1940) (no estoppel despite attorney general's knowing delay in enforcing statute). In nost of the cases cited supra in notes $122-24$, the governmeut was the plaintiff, but the courts' reasoning typically conditioned the suspension of traditional equitable balancing on the existence of the statutes rather than on the plaintiffs status. An exception is the statement in San Francisco that estoppel (and presumably laches) would not be applied to the U.S. Government. 310 U.S. at 32 .

126. Virginian Ry. v. System Fed'n No. 40, 300 U.S. 515 (1937).

127. 45 U.S.C. $\$ \S 151-163$ (1976).

128. 11 F. Supp. 621 (E.D. Va. 1935), affd, 84 F.2d 641 (4th Cir. 1936), affd, 300 U.S. 515

(1937).

129. 300 U.S. at 552 (citation omitted).

130. 310 U.S. 16 (1940).

131. See briefs in Hecht, reprinted in 88 L. Ed. $754-55$ (1944). The San Francisco case was also heavily relied on in the Alaska pipeline case, Wilderness Soc'y v. Morton, 479 F.2d 842, 847, $891-93$ (D.C. Cir.), cert. denied, 411 U.S. 917 (1973).

132. Act of Dec. 19, 1913, Pub. L. No. 63-41, 38 Stat. 242. 
the federal grants by selling power to the Pacific Gas and Electric Company. In rejecting a variety of equitable defenses ralsed by the city, the Court declared: "We are satisfied that this case does not call for a balancing of equities or for the invocation of the generatities of judicial inaxims. . . . Congress provided 'that the [defendant] shall at all times comply with and observe ... the conditions specified in this Act ...." "133 The dccision, grounded in the argument that Congress had already balanced the equities, would seem to leave no room for the balancing that the Hecht Court was later determined to undertake. By separatimg equity into its three functional aspects, however, the apparent conflict between the two cases disappears.

In San Francisco the city tried to raise threshold equitable defenses; it also sought judicial permission to contmue the statutorily prohibited conduct. In other words, the city sought balances in the first and second equitable arenas. The Court rejected the city's position, holding that Congress had balanced the equities as to both types of alleged discretion and that the defendant's conduct accordingly could not be permitted to contimue. In contrast, Hecht did not require any balancing in the first two equitable arenas. Rather, Hecht turned only on the final discretionary balance as to choice of remedy, a choice not at issue in San Francisco. In both cases the Court required strict compliance with the statute.

Recogmition of the distmction between determinations of future conduct and choice of remedy would liave saved the Court some embarassinent in Hecht, for it would lave enabled it to distinguish between the perplexing mass of prior cases variously granting and denying injunctions whichl liad been cited to the Court. Each of these prior cases, however, was consistent witl Hecht. Those not based on statute were subject to full equitable discretion. ${ }^{134}$ In those involving statutes, on the other hand, the courts consistently required compliance but differed in issumg injunctions. The latter decision depended-as it does in nonstatutory settimgs - on whether the violations were likely to continue unless enjomed. ${ }^{135}$

133. 310 U.S. at 30 (quoting Act of Dec. 19, 1913, Pub. L. No. 63-41, 38 Stat. 242). Here too it is clear that the court retained some discretion; it issued an injunction because it found it "both appropriate and necessary" to achieve the statutory ends. Id. at 31.

134. See, e.g., Meredith v. Winter Haven, 320 U.S. 228 (1943), cited in Hecht, 321 U.S. at 329; Pennsylvania v. Williams, 294 U.S. 176, 182-83 (1935).

135. In addition to San Francisco, see, e.g., Oregon \& Cal. R.R. v. United States, 238 U.S. 393 (1915) (railroad land grants could be resold to settlers only according to statute; six-month moratorium to allow congressional action on timber cutting by railroad, which was not covered by statute); United States v. Trinidad Coal \& Coking Co., 137 U.S. 160 (1890) (illegal purchases of federal mineral grants would be enjoined despite equitable threshold and utihty arguments); Buscaglia v. District Court, 145 F.2d 274 (1st Cir. 1944) (illegal emergency disbursement of funds enjomed where no appropriations act), cert. denied, 323 U.S. 793 (1945); United States v. Killoren, 
The lone prior case where a party who seemingly violated a statute had not been held to compliance was United States ex rel. Greathouse v. Dern, ${ }^{136}$ cited by Justice Rehnquist in support of his Hill dissent. $^{137}$ There, a citizen brought an action in mandamus-a legal writ that turns on equitable principles ${ }^{138}$ - seeking a permit to build a wharf directly in the path of the George Washington Parkway, then under construction. The Court understandably thought it futile to grant a permit for a structure that would immediately be razed, ${ }^{139}$ witl no consequence beyond heightened condemnation damages. It denied rehef. In examining whether Dern contradicts the principle of mandatory enforcement, it is important to note that it was never clear whether the defendant had violated any statute in refusing to issue a permit. The Court treated the case as one based on general property rights rather than on particular statutory rights or violations, ${ }^{140}$ in effect making Dern into a common law case. The legal cause of action was accordimgly nullified by the well-established principle that a "court in its discretion may refuse mandamus to compel the doing of an idle act." 141 Thus, Dern is a shallow spring in which to find a source of precedent for equitable overrides of substantive statutes.

\section{The Hecht Principles, Post-Hecht}

Despite a tendency in the Hecht opimion, and in equity commentary generally, not to make clear distinctions between the three different roles of equitable discretion, the case law since 1944 has been remarkably consistent with the principles discerned in Hecht.

After Hecht, the OPA conformed its procedures to the new stringencies in obtaming imjunctions. To implement its policy of dramatic deterrence by example, the OPA shifted to inore extensive use of treble damage suits. ${ }^{142}$ It still sought injunctions in some cases, and courts

119 F.2d 364, 366 (8th Cir. 1941) ("The plain mandate of the law cannot be set aside because of considerations which may appeal to referee or judge as falling within general principles of equity jurisprndence.") (quoting Southern Bell Tel. \& Tel. Co. v. Caldwell, 67 F.2d 802, 802 (8th Cir. 1933), which quotes Burton Coal Co. v. Franklin Coal Co., 67 F.2d 796, 797 (8th Cir. 1933)).

136. 289 U.S. 352 (1933).

137. 437 U.S. at 213 (Rehnquist, J., disseuting).

138. 289 U.S. at 359.

139. Id. at 360 .

140. Neither the language of the 1785 statute securing "full property in the shores of Patowmack River" nor the 1899 rivers and harbors appropriations act appears to have created a statutory duty on the part of the defendant secretary to issue a permit. The Court noted six areas of doubt about the plaintiff' alleged rights, 289 U.S. at 357-58, which makes its holding, based on general equitable discretion, seem far more a traditional balancing of a nonstatutory claim.

141. Id. at 360 .

142. James interview, supra note 79. Professor James said the OPA attorneys thought that treble damage awards, like criminal peualties in price fixing cases, "really got the attention of the white collar crowd." Id. 
sometimes granted them. ${ }^{143}$ The subsequent decisions tracked Hecht and the prior statutory cases in each of the three areas of equitable discretion. Threshold questions could be construed far less stringently than in common law hitigation. ${ }^{144}$ Courts uniformly held the adequacy or madequacy of legal remedies irrelevant because of the statutory grant of mjunctive power, ${ }^{145}$ but they uniformly required comphance with the Price Control Act. ${ }^{146}$ And the reinedy question-whether injunctions would issue in particular cases-turned on whether such orders were necessary to achieve compliance.

When OPA attorneys sought injunctions, they accepted the need for more proof than the inere existence of past violations. Although it is not perfectly clear where the burden of equitable persuasion lay-on the defendant to show wlyy the statutorily authorized injunction should not issue, or on the OPA to slow why it should ${ }^{147}$ - the elements of the equitable decision on choice of remedy followed Hecht. Present cessation of violations did not constram the courts' options; they could choose to enjoin or not, depending on the likelihood of future compliance. ${ }^{148}$ Where past statutory violations had been proved, three elements consistently reappear in the decisions: whether violations had been promptly and effectively discontmued, whetler these violations had been committed mistakenly in good faith, and whether in the court's estimation the defendant's attitude and reputation lent credence to promises of future compliance. ${ }^{149}$

Subsequent case law in other areas has demonstrated the same consistency with Hecht. There is, of course, a general lack of clarity in the courts' analysis of just what it was that Hecht meant. Some courts have declaimed generally about the broad powers of equity to implement discretionary justice; ${ }^{150}$ but apart from a few scattered dicta, no

143. See, e.g., Bowles v. Perez Rodrigues, 2 WAR L. SERv. (CCH) \ 52,184 (D.V.I. 1945).

144. See, eg., Bowles v. W.W. Elzea, Inc., 59 F. Supp. 1012 (S.D.N.Y. 1945) (neither OPA's alleged unclean hands nor defendant's good faith were bars to public interest enforcement).

145. Note, supra note 96 , at 1026 n.12.

146. No subsequent OPA cases permitted statutory noncounpliance to contimue on a balancing of equities.

147. The existence of past violations seems to create a judicial predisposition toward the injunctive remedy. See Commodity Futures Trading Comm'n v. Hunt, 591 F.2d 1211, 1220 (7th Cir.) ("While past misconduct does not lead necessarily to the conclusion that there is a likelihood of future misconduct, it is highly suggestive of future violations."), cert. denied, 442 U.S. 921 (1979).

148. See, e.g., Bowles v. Sinon, 145 F.2d 334, 337 (7th Cir. 1944) (holding that district court abused its discretion in denying injunctions where defendant was "uncooperative and hostile" and there were "repeated violations" with "flagrant disregard for . . . warnings").

149. Note, supra note 96, at 1028. This Note was largely based on the OPA experience, and drew on extensive OPA files in the possession of Professors Emerson and James who laad worked in the OPA Counsel's Office. See supra notes $79,84$.

150. See, e.g., Mills v. Electrie Auto-Lite Co., 396 U.S. 375, 386 (1970). The opinion also 
court has contended that Congress lacks the power to eliminate all equitable discretion from cases brought pursuant to statutes. ${ }^{151}$ Instead, the question is whether the power has been explicitly exercised. "Unless a statute in so many words, or by a necessary and imescapable inference, restricts the court's jurisdiction in equity, the full scope of that jurisdiction is to be recognized and applied. 'The great principles of equity, securing . . . complete justice, sliould not be yielded to light inferences ...."

When Congress has explicitly altered the traditional practices of equity, the courts have confirmed its power to do so. In Yakus v. United States, ${ }^{153}$ a price control case following closely on Hecht's heels, the petitioners complained that because Congress had invested the OPA with exclusive initial jurisdiction over the question of the constitutionality of the Price Control Act, they were denied the remedy of imterlocutory injunctions against enforcement that would have been available in a court. The Supreme Court somewhat disingenuously noted that Congress, in statutorily denying interlocutory equitable relief, "has only done what a court of equity could have done. . . . The legislative formulation of what would otherwise be a rule of judicial discretion is not a denial of due process or a usurpation of judicial functions." 154

The Yakus Court cited a host of other Congressional alterations of the equity power in support of this proposition. ${ }^{155}$ Congress, however,

made clear, however, that equity was to provide "such remedies as are necessary to make effective the Congressional purpose." Id.

151. Commodity Futures Trading Comm'n v. Hunt, 591 F.2d 1211, 1220 (7th Cir.) ("Injunctive relief is never automatic . . . ."), cert. denied, 442 U.S. 929 (1979). A concurring opinion by Chief Justice Stone in NLRB v. Cheney Cal. Lumber Co., 327 U.S. 385 (1946), which einphasized the court's residual power "to frame its own injunction consistently with the record," id. at 390 (Stone, C.J., concurring), has been imterpreted by some commentators as an assertion that legislative tampering with the basic equity discretion of a court under article III inight be held an unconstitutional restriction on judicial power. Note, supra note 96 , at $1027 \mathrm{n} .17$. It is far from clear, however, whether the opinion was asserting so broad a claim. Rather, Chief Justice Stone seems to have been echoing the remedy-tailoring discretion secured shortly before in Hecht. 327 U.S. 390-91 (Stone, C.J., concurring).

152. Porter v. Warner Co., 328 U.S. 395, 398 (1945). The Court subsequently used a statute, again § 205(a) of the Emergency Price Control Act of 1942, ch. 26, 56 Stat. 23, 33, to obviate the traditional discretionary concern for adequacy of legal relnedies. United States v. E.I. du Pont de Nemours \& Co., 366 U.S. 316, 328 (1961).

153. 321 U.S. 414 (1944).

154. Id. at 441-42. The Yakus Court seems to have ignored the petitioner's main point-that the agency did not provide readily available interlocutory appeals-and instead focused on the petitioner's failure to exhaust administrative remedies. The Court recognized that the traditional equity jurisdiction had been reinoved from the district courts by the Act; it deferred to the statutorily created review procedure provided by $\S 204(d)$. Id. at 429 . Jnstice Rehnquist missed the statutory imperative of Yakus when he cited the case for the general proposition of equitable flexibility in his TVA v. Hill dissent, 437 U.S. 153, 313 (1978) (Rehnquist, J., dissenting).

155. 321 U.S. at 442 n.8. An analogous example in the area of Native American land titles, 25 U.S.C. $\$ 640$ d-17(b) (1976), specifically waives laches and the statute of limitations. 
has generally chosen not to displace the equity jurisdiction. It has rarely removed equity's threshold discretion, leaving these initial issues to the judgment of equity courts, tempered by the public policies of the acts in question. As to the second area of decisionmaking, Congress has left the obligation of statutory compliance as an unstated presumption. And, as to clioice of remedy, whatever Congress' true intention was in the 1942 Price Control Act, no statute passed simce then appears to have preempted the reinedy question by requiring that injunctions issue automatically on proof of violations. ${ }^{156}$

\section{The Undisturbed Areas of Discretion}

The first and third functional areas of equitable balancingthreshold questions and the tailoring of remedies-survived the imposition of statutory causes of action relatively undisturbed, once they weathered the storm of OPA allegations in Hecht that Congress had expressly dictated remedies for price control violations. Before going to the second, nore controverted, area of discretionary balancing, it is wortliwhile to note that statutes nevertlieless do liave an effect $\mathrm{m}$ the first and third areas as well.

\section{a. Threshold Balancing}

Statutory declarations of the public interest have continued to affect threshold equitable questions. Especially when a government entity is the plaintiff, courts construe the traditional restraints against invoking equity less stringently. ${ }^{157}$ Although claims based on laclies and otlrer estoppels may still liave some success, ${ }^{158}$ the other threshold issues are rarely subject to equitable balancing. Courts typically ignore the existence of purportedly adequate legal remedies where statutes have authorized equitable remedies, ${ }^{159}$ defendants' bad faith is not a necessary element, ${ }^{160}$ and an allegation that a particular statute would be violated is a sufficient pleading of irreparable injury. ${ }^{161}$ Further-

156. Cf. Labor Management Relations Act, § 206, 29 U.S.C. $\$ 178$ (1976), quoted infra at text accompanying note 199.

157. See Commodity Futures Trading Comm'n v. Hunt, 591 F.2d 1211, 1220 (7th Cir.) ("Actions for statutory injunctions need not meet the requirements for an imjunction imposed by traditional equity jurisprudence. Once a violation is demonstrated, the moving party need show only that there is some reasonable likelihood of future violations."), cert. denied, 442 U.S. 921 (1979). See also United States v. Diapulse Corp., 457 F.2d 25, 28 (2d Cir. 1972); FTC v. Rhodes Pharmac. Co., 191 F.2d 744, 747 (7th Cir. 1951).

158. See, e.g., United States v. Pennsylvania Indus. Chein. Corp., 411 U.S. 653 (1973); Moser v. United States, 341 U.S. 41 (1951); Klein v. SEC, 224 F.2d 361 (2d Cir. 1955). See also Note, Equitable Estoppel of the Government, 47 BROOKLYN L. REv. 423 (1981).

159. Porter v. Warner Co., 328 U.S. 395, 399 (1945).

160. Albemarle Paper Co. v. Moody, 422 U.S. 405, 422 (1974).

161. United States v. Hayes Int'l Corp., 415 F.2d 1038, 1045 (5th Cir. 1969) (preliminary 
more, the public policy represented by the statute is a compelling constraint even where plaintiffs are nongovernmental. ${ }^{162}$ Where citizens are acting as private attorneys general, they may be recognized as playing a role which is "a necessary supplement to commission action."163

A lessening of plaintiff's threshold burdens in statutory cases represents a relatively uncontroversial form of legislative effect on equitable discretion. The lack of controversy may reflect a line of analysis that views these loosened tests as the product of judicial balancing rather than congressional fiat (except in a few instances where Congress has specifically restricted threshold questions). ${ }^{164}$ If the courts theinselves choose to eclipse traditional concerns in the light of statutory definitions of public interest, it renains equity's own balance. The language of some cases, however, implies that statutes represent a inore stringent and direct limitation of the threshold balance. In one early case, for example, the Supreine Court declared that "laws . . . are operative and obligatory until repealed. This . . . answers all . . . contentions of the railroad company based on waiver, acquiescence and estoppel and even to the defenses of laches and the statute of limitation. The laws which are urged as giving such defenses ... have no application." 165

\section{b. Tailoring the Remedies}

In the third arena of equitable balancing-the choice of remedies to enforce the determination of future conduct-courts since 1944 have exercised discretion in a inanner consistent with Hecht. The courts exercise discretion, but it is a discretion bounded by "the duty of giving complete and efficacious effect to the prohibition of the statute." 166

injunction case) ("irreparable injury should be presumed froun the very fact that the statute has been violatcd"). Accord United States v. Diapulse Corp., 457 F.2d 25, 28 (2d Cir. 1972) ("The passage of the statute is, in a sense, an implied finding that violations will harm the public and ought, if necessary, be restrained."); Studebaker Corp. v. Gittlin, 360 F.2d 692, 698 (2d Cir. 1966); Shafcr v. United States, 229 F.2d 124, 128 (4th Cir. 1956).

162. See Studebaker Corp. v. Gittlin, 360 F.2d 692, 698 (2d Cir. 1966) (uoting the role of citizens as recognized in stockholder actions under the Securities Exchange Act and saying that "the fact that enforcement is by a private party rather than the agency should not be controlling.").

163. Id.

164. See supra text accompanying notes 121-25.

165. Oregon \& Cal. R.R. v. United States, 238 U.S. 393,427 (1914). This language focuscs on the effict of laws, not on the fact that the government is the plaintiff. The presence of a governmontal plaintiff changes the balance since laches is geuerally not thought to apply against the government, and estoppel by the acts of officials is disfavored. See, e.g., United States v. San Francisco, 310 U.S. 16, 32 (1940); Utah Power \& Light Co. v. United States, 243 U.S. 389, 409 (1917). Cf. United States v. Lazy FC Ranch, 481 F.2d 985 (9th Cir. 1973) (demonstrating that estoppel by official misrcpresentation can lie against the government, at least where criminal penalties are involved); accord Klein v. SEC, 224 F.2d 861 (2d Cir. 1955).

166. United States v. American Tobacco Co., 221 U.S. 106, 185 (1910). See also United 
Remedies are to be tailored to achieve statutory compliance, not punishment, ${ }^{167}$ and "[t]he court . . . has a heavy responsibility to tailor the remedy to the particular facts of each case so as to best effectuate the remedial objectives." 168 As in Hecht, however, this does not mean that any remedial order necessarily has to issue.

In Rondeau v. Mosinee Paper Corp. ${ }^{169}$ for example, a corporation sought to block voting or further stock acquisitions by a potential takeover figure, based on the latter's violation of the Williams Act, ${ }^{170}$ which requires public notice to be given by any person acquiring more than five percent of a corporation's outstanding shares. ${ }^{171}$ Writing for the majority, Chief Justice Burger refused to grant injunctive relief. The defendant had made a full, though tardy, public disclosure; the violation was neither willful nor likely to recur; and no future injury would be attributable to the ship. "Thus, the usual basis for injunctive relief, 'that there exists some cognizable danger of recurrent violation," "172 was not present. Justice Brennan unsuccessfully argued in dissent that an injunction should issue automatically because the act was "a prophylactic measure" and that proinpt imjunctions to order divestiture or to bar voting of the stock were necessary to provide deterrence. ${ }^{173}$

In Rondeau the Court-neither desiring nor feeling compelled by necessity to issue an injunction-used the less coercive device of a declaratory judgment. In many such cases, particularly those involving governmental defendants, the remedy of a declaratory judgment is cho-

States v. City of Parma, 661 F.2d 562, 576 (6th Cir. 1981) ("Courts must carefully tailor the remedy in cases of statutory violations, limitimg it to relief necessary to correct the violations.")

167. Walling v. Clinchfield Coal Corp., 159 F.2d 395, 399 (4th Cir. 1946). See also Unitcd States v. Pent-R-Books, Inc., 538 F.2d 519, 523 (2d Cir. 1976) ("[C]ompliance orders are not punitive, but directory."), cert. denied, 430 U.S. 906 (1977).

168. Gilbertville Trucking Co. v. United States, 371 U.S. 115, 130 (1965). The phrase "best effectuate" raises an interesting side issue. Is the court constrained to issue the best remedy to ensure defendants' compliance? A full injunction would always seem to add a bit more to defendants' inclination to comply, even if only marginally. Or is it to select the best remedy to achieve compliance consonant with the needs of the surrounding public interest, in which case the question of scope of discretion again arises? It may be, for example, that equity will assign a value in its balancing to the voluntariness of compliance, reflecting a presumption of residual lawfulness or good faith in citizens of the democratic state. In any event, there seems to have been no academic or judicial exploration of this question.

As noted below, the "best effectuate" language does not permit a court to postpone compliance to ease the transition, a remedy which would constitute a judicial override in the short rather than long term, but an override nevertheless. See infra notes 264-73 and accoinpanying text.

169. 422 U.S. 49 (1975).

170. 15 U.S.C. $\& 78$ in(d) (Supp. IV 1980).

171. 422 U.S. at 55.

172. Id. at 59.

173. Id. at 65 (Breunan, J., dissenting). Joined by Justice Douglas, Justice Brennan's dissent focused on deterrence of future actions becanse the past violation lad becn corrected. Justice Douglas joined in this opinion notwithstanding his reasoning to the contrary when he rejected similar arguments advanced by the OPA in Hecht. See supra text accompanying notes 84-86. 
sen because the courts presume, or wish to presume, that an injunction is not necessary to achieve the defendant's comphance. ${ }^{174}$ Such restraint may indicate that some judges sitting in equity assign a positive normative value to noncoerciveness, where possible, in the tailoring of remedies. ${ }^{175}$ But even in these cases the courts imphicitly or exphcitly preserve the "plaimtiff's right to seek additional rehef at a later time should it become apparent that the declaratory judgment is not being complied with by the defendants." 176

The question of likelihood of future compliance is open to the full scope of equitable discretion. Mere cessation of violations does not forestall it, nor does good faith or a balancing of lianns. ${ }^{177}$ The likelihood of compliance is determined by the court's evaluation of the defendant's past willfulness, ${ }^{178}$ past fraudulent conduct, ${ }^{179}$ negligence or lack of diligence, ${ }^{180}$ the frequency of past violations, ${ }^{181}$ and other indicia. ${ }^{182}$ Defendant's continued refusal to admit that past actions were unlawful tends to show that illegal conduct will continue, while voluntary discontmuance prior to official enforcement indicates the opposite. ${ }^{183}$

In making compliance the focus of the remedy question, the courts have nevertheless blurred an incorporated issue. Is it an abuse of discretion for a court to issue an imjunction without finding that the "extraordinary remedy" is necessary to achieve compliance? Or is there a presumption-rebuttable by a clear slowing that recurrence is unlikely - that, where past violations are proven, future violations will be enjomed? The cases seen to argue for the rebuttable presumption. Though it is not rare for lower courts to be reversed on grounds of abuse of discretion for issumg injunctions, this usually occurs where

174. See, e.g., Poe v. Gerstein, 417 U.S. 281 (1979); Douglas v. City of Jeannette, 319 U.S. 157, 165 (1943).

175. See supra note 168 .

176. Bryant v. Blanton, 463 F. Supp. 155, 157 (W.D. Tenn. 1979).

177. SEC v. Advance Growth Capital Corp., 470 F.2d 40, 53 (7th Cir. 1972) ("Respectable authority justifies injunctive relief even though infractions are inadvertent and harmless, if they are likely to recur."). See also Commodity Futures Trading Comm'n v. Hunt, 591 F.2d 1211, 1220 (7th Cir.), cert. denied, 442 U.S. 921 (1979).

178. SEC v. Advance Growth Capital Corp., 470 F.2d 40, 53 (7th Cir. 1972) (court issued injunction where "convinced that the defendants' [past] violations were not inadvertent and liarmless").

179. SEC v. Keller Corp., 323 F.2d 397, 402 (7th Cir. 1963).

180. SEC v. Resch-Cassin \& Co., 362 F. Supp. 964, 981 (S.D.N.Y. 1973). Thus, motive or state of mind is not dispositive. Jaeger \& Hadley, Equitable Uncertainties in SEC Injunctive Actions, 24 EMORY L.J. 639, 648 (1975) (citing SEC v. Van Horn, 371 F.2d 181, 186 (7th Cir. 1966)).

181. See SEC v. Culpepper, 270 F.2d 241 (2d Cir. 1959).

182. E.g., Mitchell v. Bland, 241 F.2d 808, 810 n.5 (5th Cir. 1957) (district court rehed on the defendant's "solemn promise inade in open court to one who trusted him").

183. Cominodity Futures Trading Comm'n v. Hnnt, 591 F.2d 1211, 1220 (7th Cir.), cert. denied, 442 U.S. 921 (1979); Jaeger \& Hadley, supra note 180, at 652-53. 
full compliance has already occurred or other evidence of future compliance is present. ${ }^{184}$ In otlier cases district court mjunctions are upheld in spite of evidence that violations are not likely to recur. ${ }^{185}$

The standard of review of trial court decisions on imjunctive relief is typically, but not exclusively, the abuse of discretion. This deferential standard reflects an awareness that the trial judge may be in the best position to assess the likelihood of future violations. ${ }^{186}$ The reviewing court may decide that a refusal to enjoin was an abuse of discretion; if it thinks that the district court mismterpreted the evidence upon which discretion was based, it may "find it necessary to refashion the remedies." 187 But reviewing courts have also reversed denials of injunctions on less than a finding of abuse of discretion. "[W]here it is clear that its discretion has not been exercised with an eye to the purpose of the Act ... . [courts] liave nevertheless not hesitated to reverse an order of the trial court denying an injunction without the need of a discussion of abuse [of] discretion." 188

Despite the deference usually given the trial court, it is often presumed that if a court finds a statutory violation, an injunction should issue. TVA v. Hill ${ }^{189}$ was such a case. Despite trial court dicta regarding the defendant agency's good faith attempts to comply with the statute, ${ }^{190}$ at each judicial level the question of whether agency conduct could continue was phrased as a question of whether or not an injunction would issue. This failure to discuss lesser remedies either presumed the agency's obduracy or reflected a view of the ordinariness of

184. See, e.g., Rondeau v. Mosinee Paper Corp., 422 U.S. 49 (1975), discussed stupra in text accoinpanying notes 169-73.

185. In United States v. Pent-R-Books, Inc., 538 F.2d 519, 523 (2d Cir. 1976), cert. denied, 430 U.S. 906 (1977), the court observed:

Appellant would have us read Hecht as standing for the proposition that where the issuance of an injunction would have no effect in bringing about better coinpliance with a particular statutory scheme it is an abuse of discretion to issue an injunction. . . . [T]he Court's decision in Hecht . . . specifically did not reach the question whether the district court's refusal to enter an injunction was an abuse of discretion. It did not decide, or even imply, that it might be an abuse of discretion to issue an injunction in the factual circumstances of the Hecht case. . . . There is no suggestion in the statute tliat . . . the district court nust determine that there is danger of yet a further violation . . . before a compliance order may be issued.

See also Gulf King Shrimp Co. v. Wirtz, 407 F.2d 508, 516 (5th Cir. 1969). Pent-R-Books, however, may be attributable to a rough prosecutorial principle that pornographers will be larried as ınucl as possible short of violating the first amendinent.

186. Mitchell v. Bland, 241 F.2d 808, 811 (5th Cir. 1957).

187. SEC v. Advance Growth Capital Corp., 470 F.2d 40, 53 (7th Cir. 1972).

188. United States v. Hayes Int'l Corp., 415 F.2d 1038, 1044-45 (5th Cir. 1969). See also

Mitcliell v. Ballenger, 299 F.2d 299, 300-01 (5th Cir.), cert. denied, 370 U.S. 922 (1962).

189. 437 U.S. 153 (1978).

190. The issue of good faith was not litigated by the parties, although the district court asserted the defendants' good faith in dismissing the action. 419 F. Supp. 753, 757-58, 763 (E.D. Teun. 1976), rev'd, 549 F.2d 1064 (6th Cir. 1977), affd, 437 U.S. 153 (1978). 
the injunctive remedy. The courts' inclination toward issuing injunctions inay also be attributable to judicial recognition of a certain American contumaciousness. In other societies it may be feasible and prudent to rely on voluntary obedience to judicial decisions. But to presume, for example, that American steelworkers will respond forthwith to mere judicial declarations that their strike is illegal betrays a lack of awareness of cultural reality. ${ }^{191}$ Given the hitigiousness of the Yankee race, it is httle wonder that injunctions have become a normal remedy of choice ${ }^{192}$ and that the question of whether the conduct is illegal often becoines, in effect, the same question as whether an injunction shall issue. Moreover, as we shall see in Part IV, even in cases involving government defendants, the granting of injunctions is, ironically, often the best way to preserve the sensitive distribution of functions ainong the separate branches of government.

\section{Statutory Displacement of Equitable Discretion in Defining Proscribed Conduct}

In the thirty-eight years since Hecht, the courts have followed, albeit without inuch exphicit statement or recognition, the primciple that equity enforces whatever rules of conduct Congress chooses to define. In Izaak Walton League of America v. Butz, ${ }^{193}$ for instance, the court enforced an apparent statutory technicahty without hesitation. The court's discussion focused alinost completely on the question of whether the defendant's tree-cutting practices violated several arguably obsolete provisions of the Forest Service Organic Act of $1897 .{ }^{194}$ After interpretimg the statute and finding that it was violated, the court granted declaratory and injunctive relief with only the briefest citation to United States v. City \& County of San Francisco. ${ }^{195}$ Similarly, several labor cases have rejected atteinpts to justify noncoinpliance with statutory back pay requirements through judicial balancing of the defendant employer's hardships. ${ }^{196}$ And in a recent case the Supreme Court ob-

191. Even compliance with mjunctions is far from sure. See, e.g., NLRB v. Sears, Roebuck \& Co., 421 U.S. 132 (1975) (federal defendant); Walker v. Birmingham, 388 U.S. 307 (1967) (private defendants); United States v. Barnett, 376 U.S. 681 (1963) (state defendants).

192. O. Fiss, supra note 2, at cli. 11I.

193. 522 F.2d 945 (4th Cir. 1975), discussed infra in text accompanying notes 294-97.

194. 16 U.S.C. $\$ \S 475-482$ (1976). See 522 F.2d at 946-54.

195. 310 U.S. 16 (1940), cited at 522 F.2d at 955.

196. See, e.g., McLeod v. General Elec. Co., 257 F. Supp. 690,709 n.15 (S.D.N.Y. 1966) (preliminary injunction case), where the court observed: "The court is urgently invited by respondent to 'balance the equities'. Sufficient reason lias been indicated already for declining the invitation; the Congress substantially struck the balance wlien it wrote Section 10(j) [of the National Labor Relations Act]." The argument that Congress has already balanced the equities contimues to be a useful way to define the Hecht distinction, although it does not make clear which equitable balance was there involved. See TVA v. Hill, 437 U.S. 153, 194 (1978); House Hearings on Endangered Species: Oversight Before the Subcomm. on Wildlife Conservation of the House Comm. on 
served: "It is true that '[e]quity eschews mechanical rules . . . [and] depends on flexibility' . . . . But when Congress invokes the Chancellor's conscience to further transcendent legislative purposes, what is required is the principled application of standards consistent with those purposes and not 'equity [which] varies like the Chancellor's foot.' "197

Although the Hecht distinctions have not generally been articulated, a series of complex post-Hecht cases has tested the proposition offered here that when a statute defines proscribed conduct, courts retain no equitable discretion to override the statutory mandate.

\section{a. The Steelworkers Case}

The national steel strike of 1959 produced a particularly convoluted example of the way the three separate equitable questions become imtermingled in modern case law. When the strike appeared inevitable, President Eisenhower, acting under authority of the 1947 Labor Management Relations Act, ${ }^{198}$ asked a district court to enjoin it. The statute gave the court "jurisdiction to enjoin any such strike [for eighty days] . . . and to make such other orders as may be appropriate" upon findimg that a strike's continuation will "imperil the national health or safety."199 Arthur Goldberg, counsel for the steelworkers umion, raised

Merchant Marine and Fisheries, 94th Cong., 1st Sess. $97-98$ (1975). For further examples of labor cases rejecting attempts to justify noncompliance with statutory backpay requirements, see Franks v. Bowman Transp. Co., 424 U.S. 747 (1976); Albemarle Paper Co. v. Moody, 422 U.S. 405 (1974); Mitchell v. Robert DeMario Jewelry, Inc., 361 U.S. 288, 296 (1960) ("The statutory purposes [leave] hittle room for the exercise of discretion not to order reimbursement . . . "); Wirtz $v$. Malthor, Inc., 391 F.2d 1, 3 (9th Cir. 1968) ("It must be remembered that [requiring back pay for withheld] minimum wages and overtime compeusation is meant to vindicate a public rather than a private right, and that the withholding of the money due is considered a continuing public offense."). For cases refusing on similar grounds to create equitable expansion of the statutory exemptions under the Freedom of Inforination Act, 5 U.S.C. $\$ \$ 551-559$ (1976 \& Supp. III 1979), see Tennessean Newspapers, Inc. v. FHA, 464 F.2d 657, 661 (6th Cir. 1972); Soucie v. David, 448 F.2d 1067, 1077 (D.C. Cir. 1971).

197. Albemarle Paper Co. v. Moody, 422 U.S. 405, 417 (1974) (brackets im original). See also United States v. Stoeco Homes, Inc., 498 F.2d 597, 611 (4th Cir. 1974) ("No balancing of interests or need to show irreparable injury is required when an imjunction is sought under [the statute] to prevent erection or seek removal of an unlawful structure . . . "); Central Presbyterian Church v. Black Liberation Front, 303 F. Supp. 894 (E.D. Miss. 1969).

198. Ch. 120, $\S \S 201-212,61$ Stat. 136, 152-56 (codified at 29 U.S.C. $\$ \S 171-182$ (1976 \& Supp. III 1979)).

199. Id. $\S 208,61$ Stat. at 155 (current version at 29 U.S.C. $\$ 178(1976)$ ). Note that in this Act, as in the Price Control Act underlying Hecht and Yakts, the statutory language strongly implied that comphance must occur by specifically authorizing injunctive remedies for violations. It could perhaps be argued that Hecht, Yakus, and Steelworkers are accordingly idiosyncratic. The argument fails, however, in light of the large number of cases that make the Hecht distinction in practice, going back at least to United States $v$. San Francisco, where no such congressional declaration of remedies existed. In the text of Hecht, Yakus, and Steelworkers, moreover, the Court made no overt linkage between the specification of remedy and the need for compliance, instead presuming the latter an independent constant. Hence, the proposition from Hecht appears generally applicable. 
a barrage of arguments against the nationwide injunction which had been granted ${ }^{200}$ and affirmed on appeal to the Third Circuit. ${ }^{201} \mathrm{He}$ argued that national health and safety were not imperiled; other injunctive remedies were available to the President; the injunction would skew collective bargaining; the umion had consistently acted in good faith; and major questions of national labor policy were involved that should be decided by Congress and its agencies, not by the courts. He further argued that if an injunction were to issue, it should not be a blanket industrywide injunction, but rather an injunction tailored to demonstrated national injuries. ${ }^{202}$

Part of the murkiness of the Steelworkers case lies in a general uncertainty about what conduct the statute prohibited. Moreover, by the statute's terms, it was the court, not the executive or legislative branches, that was to declare the relevant standards of conduct ${ }^{203}$ in each case, apply thein to the facts, and require enforcement if necessary. The Supreme Court issued a vague four page per curiain opinion finding a peril to national safety based upon steel consumption in defense prograins, rejecting the threshold arguments, ${ }^{204}$ asserting the constitutional propriety of delegating such questions to courts as a sort of innovative public nuisance action, ${ }^{205}$ and affirming the grant of a nationwide injunction. ${ }^{206}$ These issues were debated at far greater length in a dissent written by Justice Douglas, who had written for the inajority in Hecht, and in a long concurring opinion by Justice Frankfurter, whose emgmatic concurring opinion in Hecht had einphasized equitable discretion.

Justice Frankfurter's concurring opinion, filed a month after the 1najority and dissenting opinions, ${ }^{207}$ had a difficult time explaining what the short inajority decision had meant. First, Justice Frankfurter asserted that the district court had broad discretionary authority to define what acts imperiled national health or safety. ${ }^{208} \mathrm{He}$ argued, in other words, that the statute gave the courts a free hand in defining

200. 178 F. Supp. 297 (W.D. Pa. 1959).

201. 271 F.2d 676 (3d Cir. 1959).

202. United Steelworkers v. United States, 361 U.S. 39, $41-43$ (1959).

203. Id. at 40 .

204. The Court noted that "Congress was not coneerned with the merits of the parties' positions or the conduct of their negotiations," Id. at 41, and continued, "We do not believe that Congress in passing the statute intended that the issuance of mjunctions should depend upon judicial inquiries of this nature." Id.

205. The court recognized that, even if the statute did not set up any rule of conduct for employers or labor, it nevertheless set up "certain rights in the public" that were litigable at the instance of the Government. Id. at 43.

206. Id. at 44 .

207. Id. at 44 (Frankfurter, J., concurring).

208. Id. at $47-48$. 
what conduct constituted a statutory violation (part of the second equitable inquiry). Then he had to argue that once the courts had determined that a violation existed, they had no discretionary authority but to issue a blanket eighty-day injunction. ${ }^{209}$ Frankfurter implied that Congress had permitted-indeed required-discretion in the difficult area of defining conduct but had sharply circuinscribed discretion regarding the usually less significant issue of choice of reinedy. Frankfurter attempted to show why a court exercising its remedy-tailoring discretion might well have to issue a blanket mjunction. "The steel industry is too vast and too coinplicated to be segmented," in inarked contrast to the situation in Hecht, where it was relatively simple to finetune a reinedy. ${ }^{210}$

Justice Frankfurter's major argument rested on the statutory displacement of equitable discretion. He read the grant of "jurisdiction to enjoim . . . and to make such other orders" as significantly stricter than Hecht's jurisdiction to issue an injunction "or other order,"211 and concluded that the issuance of mjunctions was mandatory. ${ }^{212}$ Frankfurter, who had seemed to imply the primiacy of equitable discretion im Hecht, now asserted statutory primacy over equity, whether or not the basis upon which Congress and President acted "were ill-founded . . . invalidated by experience . . . [or] found wanting by hindsight." 213

Justice Douglas' inain argument im dissent was that, as in Hecht, a grant of jurisdiction to issue injunctions did not mandate their issuance if circumstances permitted enforcement through lesser orders. He argued that the district court should have been instructed on remand to exercise its discretion to inake particularized findings, which would enable it to fashion only as limited an injunction as necessary to effectuate the statute. ${ }^{214}$ Congress did not, and would not have wanted to, require broad mjunctions. "We should hesitate long before we conclude that Congress intended an injunction to issue against 500,000 workers

209. Id. at 55-56.

210. Id. at 49 (quoting the court of appeals).

211. Id. at 59 (emphasis added).

212. Id. at 56 ("[U]nder the national emergency provisions of the Labor Management Relation Act it is not for judges to exercise conventional 'discretion' to withhold an 'eighty-day' injunction npon a balancing of convemences."). It is interesting to note that Justice Frankfurter spoke of balancing the convemiences as to the question of renedy, while the question of conduct abatement to which the balance is usually apphed had already been determined in his analysis. In his discussion of the need for a blanket injunction, he thus may have been implicitly incorporating the question of whether striking by the "noncritical" steelworkers violated the statute and wanted to reaffirm that the violation was indeed as broad as the entire industry.

213. Id. at 58. Justice Frankfurter cautioned: "These are not inatters within the Court's concern. . . . They certainly do not warrant the Judiciary's intrusion into the exercise by Congress and the President of their respective powers and responsibilities. ... Such congressional power is not to be subordinated to a sterile juristic dialectic." Id. at 62 .

214. Id. at 69-70 (Douglas, J., dissenting). 
where the inactivity of only 5000 or 10,000 of the total imperils the national 'safety," he argued. "That would be too sharp a break with traditional equity practice for us to accept, unless the statutory mandate were clear and unambiguous."215

For whatever reason-perhaps because it was a "great case . . . charged with importance and feeling"216-Justice Frankfurter had dehivered a dramatic declaration of legislative suprennacy over equitable balancing, and it has been so used by subsequent courts. ${ }^{217}$ But viewed analytically, it is not perfectly clear what his separate opimon was attempting. It superimposed a severely restricted remedy discretion (itself derived froin a rather weak statutory interpretation) upon a broadbased judicial discretion in the determination of violations. It uncritically equated the congressional command that critical strike activity be abated with a requirement that a blanket injunction issue. It skipped lightly past the traditional equitable principle of tailoring reinedies by construing the terin "enjoin" to include only the strongest form of broad prohibitory injunction, rather than the inyriad variations available. ${ }^{218}$

Even though the Steelworkers case was rife with anomalies, each opinion clearly showed a presumptive acceptance of statutory limits on equitable discretion. And as to the question of who-court or Congress-determines future conduct in statutory litigation, each opinion either imphicitly ${ }^{219}$ or explicitly presumed that a congressional directive, whatever it may be, has to be enforced by the courts.

\section{b. The Reserve Mining Litigation}

Of all the post-Hecht cases, one case of almost unprecedented complexity and duration offers the stiffest challenge to the proposition that statutes limit the court's equitable discretion to determine future conduct. The focus of the Reserve Mining ${ }^{220}$ litigation was a Minnesota

215. Id. at 71-72. See also id. at 71 ("If the federal court is to be merely an automaton stamping the papers an Attorney General presents, the judicial function rises to no higher level than an IBM machine. Those who grew up with equity and know its great history should never tolerate that mechanical conception.").

216. Id at 62 .

217. E.g., Chandler v. Judicial Council of the Tenth Circuit, 398 U.S. 74, 108 (1970) (Harlan, J., concurring); Tennessean Newspapers, Inc. v. FHA, 464 F.2d 657, 661 (6th Cir. 1972); United States v. Manning, 215 F. Supp. 272, 291 (W.D. La. 1963).

218. See supra notes $64-68$ and accompanying text.

219. The Douglas dissent was based on the premise that the statute was not violated at all, or if so, by only a small segment of the labor force, requiring only a narrowly delimited injunction.

220. An entire legal process course could be taught out of the Reserve Mining case, which involved federal and state statutory and common law; federal, state, and private plaimtiffs against corporate defendants and their labor and nunicipal supporters; with carcinogemic pollutants and the esthetics of a pristine Great Lake; air and water pollution; convoluted industrial economics and inuch chemistry and technology; nine trips to the federal district court (one hearing lasting 
iron ore mill that was daily dumping 67,000 tons of taconite sludge into Lake Superior. The case did not completely deny enforcement to the statutes involved. It did, however, permit the defendant to continue the statutory violations for a "reasonable time" potentially ranging froin three to seven or even ten years while abatement plans were implemented. ${ }^{221}$ The Reserve Mining court permitted the violations to continue after a classic balancing of overall equities, weighing the violation and health hazards against the difficulty and cost of compliance and the economic prosperity of the local commumity. ${ }^{222}$

Upon careful analysis of the byzantine proceedings, however, $R e$ serve Mining does not stand for the proposition of judicial overrides. The district court originally ordered the mill shut down in April 1974 based on violations of federal and state common law nuisance, the state air act, and the 1970 Federal Water Pollution Control Act. ${ }^{23}$ Significantly, each of these grounds implicitly or explicitly permitted the court to balance the question of abateinent. The federal Act, for instance, said: "The court, giving due consideration to the practicability and to the physical and economic feasibility of securing abatement of any pollution proved, shall have jurisdiction to enter such judgenent, and order enforcing such judgment, as the public interest and the equities of the case inay require."224 Accordingly, the district judge appropriately em-

nine months), two to the state courts, four to the Eighth Circuit, one to the Supreme Court in an unsuccessful petition to revoke a stay; mjunctions, stays, modified mjunctions, mandamus orders (also stayed, and reinstated); an elaborate permit and standard-setting administrative systeın; counterclaims by industry for tort damages owing to "neghigently issued permits"; a federal statute which, after 60 years of dormancy, suddenly imposed new prohibitions through a twist of statutory imterpretation; plus an appellate order forcing the district judge to recuse himself for bias formed in the course of trial. Reserve Mining Co. v. Minnesota Pollution Control Agency, 434 F. Supp. 1191 (D. Mnin. 1976); Umited States v. Reserve Mining Co., 417 F. Supp. 791 (D. Minn. 1976); 417 F. Supp. 789 (D. Minn.), aff'd, 543 F.2d 1210 (8th Cir. 1976); 412 F. Supp. 705 (D. Minn. 1976); 408 F. Supp. 1212 (D. Minn. 1976); 394 F. Supp. 233 (D. Minn. 1974), modified sub nom. Reserve Mining Co. v. EPA, 514 F.2d 492 (8th Cir. 1975), modified en banc sub nom. Reserve Mining Co. v. Lord, 529 F.2d 181 (8th Cir. 1976) (recusal order); 380 F. Supp. 11 (D. Minn.), stayed, 498 F.2d 1073 (8th Cir.), motion to vacate stay denied, 418 U.S. 911, motion to vacatc or modify stay denied, 419 U.S. 802 (1974) (Douglas, J., dissenting). See also Reserve Mining Co. v. Herbst, 256 N.W.2d 808 (Minn. 1977); Reserve Mining Co. v. Mninesota Pollution Control Agency, 294 Minn. 300, 200 N.W.2d 142 (1972); see N.Y. Times, Apr. 25, 1982, at 31, col. 1.

221. Reserve Mining Co. v. EPA, 514 F.2d 492, 538, 541 n.1. See infra text accompanying notes 264-73. The discharges into Lake Superior continued under the injunctive comphance schedule until 1980, when the company shifted to on-land disposal at Milepost 7. Interview with Robert Herbst, former Commissioner of Conservation for Mninesota (Dec. 23, 1981).

222. 514 F.2d at 506, 515, 520-21, 535-39.

223. 380 F. Supp. at 23-26.

224. Federal Water Pollution Control Act of 1948, ch. 758, § 2(d)(7), 62 Stat. 1155, 1157 (current version at 33 U.S.C. $\$ 1251$ (1976)). The definition of a violation of standards was subject to the same open-ended discretion, Act of Oct. 2, 1965, Pub. L. No. 89-234, § 5(c)(5), 79 Stat. 903, 909 (1965) (amended 1972), in a legislative formnlation of enforceinent inechanisms successfully designed by its drafters to be unenforceable. Cf. S. REP. No. 414, 92d Cong., 1st Sess. 5 (1971), reprinted in 1972 U.S. CODE CONG. \& AD. NEws 3668, 3672 (discussing lack of cnforcement). 
barked on a voluminous discussion of competing equities without any discussion of mandatory abatement. ${ }^{225}$

Six months later, the trial judge added a further finding that the Refuse Act, a statute which cast the abatement question in nondiscretionary terms, had also been violated, ${ }^{226}$ but since there was already an abatement injunction outstanding, the court issued no additional injunction. ${ }^{227}$ Accordingly, it was the original injunction that the court of appeals reviewed and modified..$^{228}$ Although the existence of the Refuse Act violations should have changed the nature of the debate over abatement, no one seems to have recognized the point. This may be attributable to the fact that the court subsumed that statutory violation in its own extensive discussion of health hazards which required abatement with deliberate speed. ${ }^{229}$ The Refuse Act-the only statute posing a direct statutory prohibition-was not inentioned in the court of appeals' remedies discussion. ${ }^{230}$ In fact, when the plaintiffs brought the case to the Supreme Court on interlocutory appeal, the Act was not even cited in Justice Douglas' extensive dissenting opinion in favor of an immediate injunction. ${ }^{231}$ On relnand, all discussions continued to focus on the balancing of health hazards, and the Refuse Act violation was never again mentioned with regard to the need for abateinent, falling out of sight between the procedural cracks. ${ }^{232}$

On this ineandering record it is difficult to discern a clear statutory violation or judicial recognition of a Hecht question, much less a holding or reasoning in support of equitable overrides of statutory provisions. On its own teruns and despite its appearances, Reserve Mining is essentially based upon common law standards ${ }^{233}$ rather than legislative

The Minnesota statute, MinN. Stat. ANN. § 116B.03 (West 1977), incorporated similar internal flexibility, as did, of course, the common law actions.

225. 380 F. Supp. at 29-57.

226. Rivers and Harbor Appropriations Act of 1899, $\S 13,33$ U.S.C. $\S 407$ (1976) (forbidding the placement of any "refuse" in navigable waters without a Corps of Engineers permit).

227. 394 F. Supp. at 245.

228. 514 F.2d at $535-40$.

229. The coinpany possessed a 1960 Refuse Act permit authorizing Reserve "to construct a sheet pile dock . . . and, to deposit tailings from the ore processing mill in [to] Lake Superior." Id. at 530. The court said that the permit "does not sanction a continuing discharge of foreign inaterials into the lake which are potentially hazardous to health," id. at $532 \mathrm{n.76}$, but then proceeded to weigh the question in terms of the extent to which these were indeed hazards to public health, id. at 535-38.

230. Id. at $531,536-39$.

231. 419 U.S. at 802-04.

232. See Uinited States v. Reserve Mining Co., 408 F. Supp. 1212 (D. Minn. 1976).

233. Including the codified "common law" balancing of the particular pollution statutes there involved. See supra note 224 and accoinpanying text. The court of appeals did cite United States v. City \& County of San Francisco, 23 F. Supp. 40, 53 (N.D. Cal. 1938), rev'd, 106 F.2d 569 (9th Cir. 1939), rev'd, 310 U.S. 16 (1940), which does not support a proposition of statutory overrides by equity; to the contrary, it required statutory compliance, (albeit with a six-inonth grace period, 
mandates.

\section{c. National Environmental Policy Act Cases}

Some of the last decade's National Environmental Policy Act (NEPA) ${ }^{234}$ cases present a further opportunity to test the equity analysis presented here. Indeed, recurring examples of denials of equitable relief in NEPA cases prompted one commentator to issue a broad pronouncement:

Courts thus usually balance the equities before issuing an injunction or an order of compliance for violation of environmental statutes. This balancing process is very similar to that which has developed for private nuisance. The court figures the efficiency calculus, adjusting the calculation by weighting or presuinptions derived froin the relevant social values. ${ }^{235}$

This asserts precisely the proposition that Hecht did not nuake and that this present analysis has been trymg to refute-a judicial balancing in statutory cases, not only at the uncontroversial threshold and remedy stages, but in the central question of determining conduct as well. Professor Winner rested his argunient exclusively on NEPA cases, ${ }^{236}$ but even there it is difficult to sustam.

In virtually every case, NEPA lawsuits seek injunctions on the theory that a federal project or program either does not have an environmental impact statement as required by section $102(2)(C)$ for all "n1ajor Federal actions significantly affecting the quality of the hunian environment," or that the statement which has been prepared is niadequate. $^{237}$ Given the vast nuniber of federal actions potentially subject to NEPA requirements and the recalcitrance of many agencies, it is not surprising that many violations do occur. And given the fact that environmental lawsuits seek to impose new standards of planning and design and newly declared public values on public and private decisionmaking, it is not surprising that they raise a host of competing equities.

see infra note 264) and remands to the legislature where a law was "unworkable." 514 F.2d at 537-38. In the same regard, it cited Chief Justice Burger's general caveat on reasonableness in environmental enforcement, Abderdeen \& Rockfish R.R. v. SCRAP, 409 U.S. 1207, 1217, 1218 (Burger, Circuit Justice 1972), which nevertheless on statutory grounds had denied a stay of the injunction. If Reserve Mining were to represent a conscious holding that courts can override statutes, of course, there is the further possibility that it was wrongly decided.

234. 42 U.S.C. $\$ \S 4321-4369$ (1976 \& Supp. III 1979).

235. Winner, supra note 35 , at 506 .

236. Beyond the terms of his environmental proposition, Professor Winner also cited Hecht, Steelworkers, San Francisco, J.I. Case Co. v. Borak, 377 U.S. 426 (1964), and two state cases. Winner, supra note 35 , at 506-08. In none of these did a court override the prohibitions of statutes.

237. 42 U.S.C. $\S 4332(2)(C)$ (1976). 
As Winner notes, denials of NEPA injunctions are frequent. ${ }^{238}$ As is often the case when injunctions are denied, however, in many of these cases the courts found that NEPA did not apply to the acts in question, ${ }^{239}$ or that comphance would occur even without an injunction. ${ }^{240}$ Other cases cited by Winner for the equitable balancing proposition were preliminary injunction actions (in which coinphance was nevertheless often required where clear violations existed), ${ }^{241}$ or cases where procedural coinpliance had already substantially occurred. ${ }^{242}$ It does not appear that any lower court, inuch less the Supreine Court, has ever found in a proceeding on the merits that federal actions violating NEPA could continue in opposition to the statutory mandates.

238. Most commentators and courts now concede that NEPA is a procedural statute, providing for a series of administrative reviews and disclosures, but not directing any particular substantive decisions. Thus, in cases where a project is too far along to be affected by the comprehensive environmental analysis provided in NEPA, the Act does not apply and no injunction will issue since there is no violation. See, e.g., San Francisco Tounorrow v. Romney, 472 F.2d 1021 (9th Cir. 1973); Arlington Coalition on Transp. v. Volpe, 458 F.2d 1323 (4th Cir.), cert. denied, 409 U.S. 1000 (1972); Pennsylvania Envtl. Council v. Bartlett, 454 F.2d 613 (3d Cir. 1971); East 63rd St. Assoc. v. Coleman, 414 F. Supp. 1318 (S.D.N.Y. 1976). In Conservation Soc'y of S. Vt., Inc. v. Secretary of Transp., 508 F.2d 927, 936-37 (2d Cir. 1974), vacated, 423 U.S. 809 (1975), the challenged intersection was virtually coinplete; thus, although the court discussed balancing, it appears that NEPA had no possible effect on the intersection and thus was inapplicable. The Supreme Court has noted that "NEPA essentially imposes a procedural requirement on agencies," so that NEPA case law is "completely inapposite" to cases arising under statutes imposing a substantive standard. TVA v. Hill, 437 U.S. 153, 188 n.34 (1978).

239. Environmental Defense Fund v. TVA, 468 F.2d 1164, 1174-75 (6th Cir. 1972) (the Hill Tellico Dam case in a prior incarnation); Lathan v. Volpe, 455 F.2d 1111, 1120-21 (9th Cir. 1971); Sierra Club v. Coleinan, 405 F. Supp. 53, $54-55$ (D.D.C. 1975); Atchison, T. \& S.F. Ry. v. Callaway, 382 F. Supp. 610, 623 (D.D.C. 1974).

240. In Alaska v. Andrus, 580 F.2d 465, 485-86 (D.C. Cir.), vacated in part sub nom. Western Gas \& Oil Ass'n v. Alaska, 439 U.S. 922 (1978), the inadequacy of the enviromnental impact statement was a failure to consider adequately the possibilities of adding termination clauses or stronger operating rules to offshore oil leases. The court reinanded to the Secretary of Interior for consideration of these alternatives in subsequent NEPA review and for implementation if they appeared necessary. In Enviromnental Defense Fund v. Armstrong, 352 F. Supp. 50 (N.D. Cal. 1972), the court did not issue an injunction, but rather ordered the government to coinply with a revised project schedule to assure that no actual work or environmental danuage would oceur prior to further court hearing. In the subsequent hearing, the court found the revised environmental impact statement to be adequate. 356 F. Supp. 131 (N.D. Cal.), affd, 487 F.2d 814 (9th Cir. 1973). These cases ignore the reality of the bureaucratic momentum inherent in continuation of an agency's project planning and contracting, but reflect the view that NEPA only prevents actual damage. Hence on their own terms the courts were not permitting statutory violations to continue.

241. In New York v. Nuclear Regulatory Comm'n, 550 F.2d 745 (2d Cir. 1977), the court did not clearly hold that there was a violation. In Sierra Club v. Coleinan, 405 F. Supp. 53, 54-55 (D.D.C. 1975), the preliminary injunction was issued on proof of violation. In Realty Income Trust v. Eckerd, 564 F.2d 447, 455-56 (D.C. Cir. 1977), the court denied the preliminary relief because the draft and final environmental impact stateinents, though absent when construction plans had first been presented, "have long since been coinpleted and released."

242. 564 F.2d at 455-56. In Essex County Preservation Ass'n v. Canupbell, 536 F.2d 956 (1st Cir. 1976), a preliminary injunction was denied on the ground that although a technical statutory violation had occurred through failure to get a state highway action plan approved prior to federal funding, the defect had subsequently been remedied. 


\section{d. Romero-Barcelo v. Weinberger}

Only recently, the Supreme Court was asked agam to define an equitable power to override statutory provisions in the case of RomeroBarcelo v. Weinberger. ${ }^{243}$ The Commonwealth of Puerto Rico had been eunbroiled in a longrunning dispute with the Navy over the issue of the island of Vieques as a bounbing target. In.an apparent attempt to improve his position for negotiating protections for the residents of the island, Governor Romero-Barcelo filed a lawsuit that eventually comprised some two dozen claims based on treaties and executive orders, constitutional and common law rights, and a variety of environmental and pollution statutes. ${ }^{244}$ The district court ultimately found violations of the federal Clean Water Act (which expressly includes munitions as one of many classes of pollutants requiring a federal permit), ${ }^{245}$ the National Historic Preservation Act's Executive Order No. 11,593, ${ }^{246}$ and NEPA. ${ }^{247}$ But then, in a classic exercise of unfettered balancing, the district court refused to order abatement of the bombing and instead ordered the Navy to proceed with the permit procedure "with all deliberate speed."248

The district court asserted that there was no difference in judicial balancing power between statutory and nonstatutory cases. ${ }^{249}$ It noted that injunctions are "an extraordinary remedy," citing the classic language of broad, historic equitable discretion from Hecht and Rondeau v. Mosinee Paper Co. ${ }^{250}$ As is so commonly done, however, the court failed to make the fundamental distinction, embodied in the holdings of both those Supreme Court cases, between the choice of remedy (no injunction was necessary in either case), and the abateinent decision itself (immediate coinpliance was required in both). The court then set forth to balance the equities, noting that an injunction would affect national defense, that the violations were "in substance technical violations," that the plamtiffs' requests were "drastic" and colored by laches,

243. 643 F.2d 835 (1st Cir. 1981), affg in part and vacating in part Barcelo v. Brown, $478 \mathrm{~F}$. Supp. 646 (D.P.R. 1979), cert. granted sub nom. Weinberger v. Roinero-Barcelo, 102 S. Ct. 88 (1981) (No. 80-1990).

[Editor's Note: Romero-Barcelo was reversed, Weinberger v. Roinero-Barcelo, 50 U.S.L.W. 4434 (U.S. Apr. 27, 1982), late in the publication process. See Author's Postscript infra notes 320-28 and accoinpanying text.]

244. 478 F. Supp. at 651-52.

245. 33 U.S.C. $\$ 1362(6)$ (1976).

246. 3 C.F.R. 559 (1971), reprinted in 16 U.S.C. $\$ 470$ app. (1976).

247. See 478 F. Supp. at $664,694,705$.

248. Id. at 708 (citing Brown v. Board of Educ., 349 U.S. 294, 301 (Brown II)). Each violation was susceptible to procedural correction.

249. Id. at 706 (citing six NEPA cases and coinparing statutory to constitutional cases).

250. 422 U.S. 49 (1975), discussed supra in text accoinpanying notes 169-73. 
and that plaintiffs would suffer no great harm by delay. ${ }^{251}$

On appeal the First Circuit held that this classic balancing exercise was improper. Focusing on the Clean Water Act violation, the court ordered issuance of an injunction halting the boinbing. ${ }^{252}$ Reasoning that "Congress, exercising its delegated powers, has decided the order of priorities in a certain area," so that the Navy "has an absolute statutory obligation to stop any discliarges . . . [until the Environınental Protection Agency (EPA)] lias granted a permit," 253 the court of appeals reversed the district court's exercise of a power to balance the equities.

The First Circuit's opinion also noted the existence of a statutory procedure by which the President could exempt the Navy from the Clean Water Act permit requirement in the interest of national security if the Act significantly interfered with the Navy's preparedness. ${ }^{254}$ In fact, the statute provides three different administrative exemptions whicll the Navy could lave requested: two from the President (imdividual exemptions or a broader category waiver by rulemaking) and one froin the EPA. ${ }^{255}$

Instead of applying for the statutorily prescribed waivers, the Navy sought to obtain statutory flexibility from the courts. In its petition to the Supreme Court, the Navy argued that if the Office of the President were obliged to issue individual exemptions or category waiver rules,

[The Executive] will in effect be formulating an equitable decree to satisfy the purposes and policies of the Clean Water Act. It is the role of the courts to fashion appropriate equitable relief for violations of federal law. The federal courts should not abdicate that responsibility and

251. 478 F. Supp. at 706-07.

252. 643 F.2d at 862.

253. Id. at 861 (citing TVA v. Hill, 437 U.S. 153, 194 (1978)). The court made a careful distinction with regard to Executive Order 11593 and NEPA violations, for which it said compliance had been achieved without the need for the imjunctive remedy. Id. at 862 . It made the same disposition of an endangered species claim in which it found merit. Id. at 858,863 .

254. Id. at 862 (citing 33 U.S.C. § 1323(a) (Supp. III 1979)).

255. The executive waiver provisions provide:

The President may exempt any effluent source . . . from compliance with any such a requirement if he determines it to be in the paramount interest of the Umited States to do so. . . , for a [renewable] period not in excess of one year . . . In addition . . . the President may . . . issue regulations exempting . . . any weaponry, equipment, aircraft, vessels, vehicles, or other classes or categories of property . . . which are owned or operated by the Armed Forces of the Umited States and which are uniquely military . . . . 33 U.S.C. \& 1323(a) (Supp. III 1979) (the rulemaking waivers inust be reviewed every three years). According to 33 U.S.C. $\& 1319(a)(5)(A)$, (B) (Supp. III 1979), the Environmental Protection Agency can extend final deadlines for "a time the Administrator determines to be reasonable" and could have granted extended delays pending permit issuance, prior to April 1979. The Navy argued that the individual exemption provision was "evidently intended to provide for rehef only in extraordinary circumstances, when the requirements of the Act are inconsistent with essential federal activities." Petition for Writ of Certiorari at 14-15, Romero-Barcelo. 
shift it to the Office of the President in the absence of a clear congressional direction to do so. ${ }^{256}$

This argument was supported by citations to Reserve Mining and several other lower court cases where injunctions were not issued. ${ }^{257}$ The Navy also relied heavily on Hecht, stressing its language about equity's flexibility in tailoring remedies "appropriate" to enforce a statute. ${ }^{258}$ Nowhere did it mention Hecht's distinction between the judicial tailoring of remedies and the lack of choice in requiring abatement of violations.

The Navy's inost ambitious undertaking in Romero-Barcelo was to posit a new definition of equitable discretion to circumscribe the Supreme Court's recent opinion in TVA v. Hill. ${ }^{259}$ Equity presumptively has the power to override statutes, the Navy argued, unless there are "special circumstances . . . not present here." The special circumstances occur only when two conditions are present: first, when "Congress 'has decided the order of priorities' and has made it 'abundantly clear that the balance has been struck in favor of [comphance] ...." ,260 and, second, when "the violation ... was substantial ..."261 and "directly and fundamentally in conflict with the purposes of the Act."262

The Navy's innovative test inevitably would necessitate extensive

256. Petition for Writ of Certiorari at 16, Romero-Barcelo. This argument appears to be focused on the first, quasi-adjudicative waiver, and does not appear to take account of the existence of the rulemaking waiver discussed supra at note 255 .

257. Id. at 5, 8 n.7. United States v. Kennebec Log Driving Co., 491 F.2d 562 (1st Cir. 1973), was a case in which the court found there was no violation of $\S 15$ of the River and Harbors Act, 33 U.S.C. $\$ 409$ (1976), owing to a statutory exception for logdriving. Id. $\$ 410$. 1t remanded on the question of whether the consequent incidental deposits of bark and chips were proscribed by $\S 13$ of the Refuse Act, id. $\S 407$, and briefly discussed whether, if these deposits were not exempt from the Refuse Act, the district court could consider estoppel reliance arguments and economic and practical burdens as a basis for declining to require comphiance. 491 F.2d at 570-71. The court imphed that such a balance could be made. Id. In United States v. Rohm \& Haas Co., 500 F.2d 167 (5th Cir. 1974), the question was how much cheinical discharge was perinissible without a Refuse Act permit, pending issuance of a general FWPCA-NPDES permit. The court affirmed an injunction partially restricting discharges, owing to the "highly technical" nature of the question, pending issuance of the new permit. No party apparently ever requested a total imjunction, and so the court never recognized or discussed the question whether it could permit a partial override of the old statute. See id. at $\mathbf{1 7 5}$. In these circunstances, neither case justifles the assertion that equity can override legislation.

258. Brief for Petitioners at 10,11,17, 18, Romero-Barcclo. The petitioners also cited the general mjunctive discretion section of 7 J. MOORE, supra note 2, \ 65.18[3], which deals with injunctive balancing. On the statutory question the brief merely noted without analysis that some cases like San Francisco evince "little or no discretion" and thus do not follow Hecht's broad panegyric on equitable discretion. Brief for Petitioners at 18 , Romero-Barcelo.

259. 437 U.S. 153 (1978).

260. Brief for Petitioners at 12, Romero-Barcelo.

261. Petition for Certiorari at 7, Romero-Barcelo.

262. Brief for Petitioners at 13, Romero-Barcelo. 
judicial second-guessing of the legislature, far beyond the relatively clear-cut statutory interpretation involved in determining the existence of a violation. The first element imphes a rebuttable presuinption that statutes do not necessarily represent a considered congressional choice of permitted or proscribed conduct. The second element implies that courts are to be guided by "the purposes of the Act" not only in defining the basic statutory requirements, but also in some ad hoc judicial ranking of violations in terms of substantiality or imsubstantiality, directness or indirectness, fundamentality or nonfundamentality. These questions are normally thought of as political in nature, so such a ranking would be as political as it is difficult. ${ }^{263}$ The Navy's argument asked the Court to einbark on uncharted waters, redefining both the occasion and scope of judicial discretion in overriding statutes. This is a longstanding invitation that courts have long declined to accept.

\section{e. Discretion to Postpone Compliance}

The use of delayed injunctions presents another version of judicial overrides of statutes. When the Reserve Mining court, for example, used a balancing of the equities to permit defendants to postpone compliance for a "reasonable time," it effectively created a three to ten year statutory override. ${ }^{264}$ The application of a reasonableness balance to the timing of equitable remedies would have been completely appropriate, of course, had the case been a traditional nonstatutory case. Even as it was, since the court based its decision on statutes which allowed judicial balancing, flexibility appeared to have been appropriate in that statutory setting as well. ${ }^{265}$ Where the statute being violated does not provide for such judicial balancing, however, does equity have a

263. In navigating this tricky course for the Navy, the Solicitor General's office lad to argue that the endangered species violation in Hill liad been a substantial violation of a congressionally ordered priority, a position diametrically opposed to the position they lad taken in Hill. Section 7 of the Endangered Species Act, 16 U.S.C. \& 1536 (1976) (current version at Supp. III 1979), was written with inucli circumlocution and obfuscation, so it liardly seems to represent a particularized clioice of priorities. Justice Powell was probably correct when he argued in Hill that Congress, in passing the Endangered Species Act, had not foreseen its utility in lawsuits to halt federal projects. 437 U.S. at 208-09 (Powell, J., dissenting).

264. See supra text accoinpanying note 22. Another example is San Francisco, discussed supra in text accompanying notes 130-35, where the trial court had originally delayed the effect of the injunction until six inonths after its issuance "[i]n order that the city inay face its problem and coinply with its [statutory] obhgations." 23 F. Supp. 40, 53 (N.D. Cal. 1938), rev'd, 106 F.2d 569 (9th Cir. 1939), aff'd, 310 U.S. 16 (1940). In Romero-Barcelo, the Navy's Reply Brief argued that "[t]he sole question presented in this case is whether the federal courts retain the discretion to formulate [a delayed coinpliance] reinedy without ordering immediate cessation of the violating discharges . . . " Reply Brief for Petitioners at 1-3, Romero-Barcelo. The appears to be a inajor diminution of the arguments previously inade by the petitioners, discussed supra in text accoinpanying notes 256-62.

265. See supra text accompanying notes 223-24. The court failed to realize that the Refuse Act violation made a difference. $I d$. 
residual power to grant defendants a reasonable transition time to move from noncompliance to compliance?

The argument for equitable postponements is initially compelling. A reasonable amount of time for the transition to compliance would appear to be a matter of common sense. The "common sense" assertion, however, raises questions of its own, and the "reasonable postponement" of decrees has the potential of completely undercutting the lines drawn in the cases to date.

Any judicial autliorization of noncompliance-whether for an indefinite long term or for a circumscribed sliort term-analytically requires recognition of a judicial power to override the mandates of a statute. Once asserted, sucli a power would become the arena for further troublesome questions. How long can the courts postpone compliance? Is defendant's prior good faith a prerequisite? Must the court's postponement be motivated solely by the public cost of immediate compliance, or are private burdens to the defendant sufficient? Is a financial interest enough, or must liealtl and safety issues be involved?

The preferable answer, whicl is, noreover, consistent with the logic of equity and statutes and theories of separation of powers, is that a court inust order defendants to comply with violated statutes as immediately as feasible. In inany circumstances this will mean immediate cessation of the violative conduct. ${ }^{266}$ In other cases, the courts properly may take account of the infeasibility of immediate compliance. Assume that the case arises in which immediate compliance is physically impossible, where, for exainple, a court lias determined under a water pollution statute that all dam operators must immediately obtam permits if they are to continue discharging water downstream. ${ }^{267}$ There is a siniple answer to the apparent dilemma between the statutory requirement and the realities of the situation. The answer lies in the principle that the courts cannot require the doing of an impossibility: Equity will not decree a vain thing. ${ }^{268}$ An injunction ordering immediate cessation would be useless; if issued and disobeyed, it would not be pumshed under the contempt sanction. ${ }^{269}$ On the otlier hand, an order

266. In Romero-Barcelo, for example, it would appear feasible for the Navy to cease its bombing of Vieques immediately, at the same hour requesting the President to issue an immediate waiver under his statutory power. It could conceivably resume bombing under a waiver that same afternoon. The Navy recognized this option but preferred a court-authorized delay in compliance, pending the completion of various permit procedures. Reply Brief for Petitioners at 2 n.2, Romero-Barcelo ("[A]n immediate cessation order would require the Navy to obtain a presidential exemption from the statute, despite its readiness to seek a permit and thereby bring itself into compliance with the statutory requirements.").

267. This is the not-so-hypothetical case noted supra note 28.

268. See supra notes $27-29$ and accompanying text.

269. The contempt power is a clearly discretionary power of a court sitting in equity to punish "such contempt of its authority ... as . . [d]isobedience or resistance to its lawful writ." 18 
requiring defendants to comply with the statute as soon as physically feasible would neither order the doing of the impossible, nor by its terms authorize the violation of a statute. ${ }^{270}$

The key to this equitable resolution is the word "feasible." If immediate comphance is physically or legally impossible, ${ }^{271}$ then the postponement of an injunctive order until compliance is possible does not challenge the legislature's statutory prerogative. Infeasibility and impossibility, however, can be interpreted far more broadly, im terms that would run afoul of the line drawn in Hecht and subsequent cases. If, for example, defendants found it very expensive, although possible, to comply immediately with a statute, they could argue that such coinpliance was "infeasible in the circumstances." They could, moreover, find support for this expansive reading in nonstatutory cases which lave based their holdings that equity will not order a vain thing on a judgment of what was reasonably possible in the circumstances. ${ }^{272}$

There is no way to avoid the fact, however, that as soon as a court would embark on a definition of a "reasonably feasible" standard for delayed compliance, it would take on the garb of a mini-legislature.

U.S.C. $\S 401$ (1976). It is thus unlikely that a court would feel legally obliged to punish a defeudant who failed to comply immediately because of what the court deemed reasonable or excusable constraints. And in the circumstances posited, there would undoubtedly be a strong disinclination in the opposite direction against punishing for noncompliance. There do not appear, however, to be cases asserting this proposition of discretion not to punish for conteinpt, probably because those cases which get reported on the contempt issue are those where courts are actively seeking to punish, and defendants are resisting. See, e.g., Moskovitz, Contempt of Injunctions, Civil and Criminal, 43 Colum. L. Rev. 780, 791-801 (1943). Cf. Peufield Co. v. SEC, 330 U.S. 585, 607-09 (1947) (Frankfurter, J., dissenting) (asserting the discretionary flexibility of a court to compel obedience to its subpoena).

There is a theoretical distinction between civil contempt which is designed "not to punish, but to coerce," and criminal contempt which is "pure punishunent to vindicate the court's authority and dignity." Duell v. Duell, 178 F.2d 683, 685 (D.C. Cir. 1949). See also Goinpers v. Buck Stove \& Range Co., 221 U.S. 418, 441 (1911); 7 J. MooRE, supra note 2, If 65.02[4]. In the case of criminal contempt, the court might well decide that a violation of its injunction was not such as to bring the court itself or its dignity and authority into disrespect. Further, in civil and criminal contempt cases, it inay be necessary for a party plaintiff to file a verified affidavit seeking a contempt sanction, Moscovitz, supra, at 815-17 \& n.176, so an absence of such request might well leave the court with no practical opportunity to punish for contempt. Even if a party did seek the contempt sanction, or if a court felt obliged to nonitor comphance on its own motion in the hypothesized circumstances, however, the discretionary basis of contempt noted above would seem to permit it to refrain from punishing a noncomplying defendant. Even if nonpunishunent were probable, the issuance of the injunction and the mere possibility of fine or imiprisonment would in all likelihood promote the speediest compliance that the defeudant could manage.

270. It is not an authorization of noncomplance to fail to issue an immediate injunction in such cases. An immediate imjunction order would constitute a gratuitous imposition of liability for contempt, with no functional purpose served. By declining to issue such an imjunction, a court is merely declining to issue a feckless order, not affirmatively permitting the continuing violation. If an imjunction could feasibly stop the noncompliance immediately, a denial would then indeed effectively constitute an authorization of continumg violations, which would be improper.

271. See Moffett v. City of Rock Island, 77 Ill. App. 3d 850, 854, 397 N.E.2d 457, 460 (1979).

272. See final three cases cited supra note 28. 
That small exception has the capacity to swallow the whole rule. Beyond a variety of procedural mitigations that are available-stays pending appeal and discretion in contempt proceedings, for exam$\mathrm{ple}^{273}$ - the proper line to draw appears to be the clear line: courts must order immediate compliance where it is physically and legally feasible. ${ }^{274}$ The fact that this question has not been a inajor judicial problem to date, moreover, is another eloquent indication that a inore expansive judicial role is unnecessary.

In fact, not even in emergencies have courts allowed themselves to override statutory commands. Intuitively, American jurists are inclined to posit emergencies as the liypothetical extrene case: what if the Russians were coming, or plagues were spreading in the land, so that immediate action in violation of the technical terms of a statute were needed? There are several answers to this question, all rather short. First, inany or most statutes have flexibility built into their administration. ${ }^{275}$ If not, the legislative and executive branches have shown an ability to pass necessary remedial legislation with remarkable speed. ${ }^{276}$ Furtlermore, if the Russians wcre coming, it would no doubt

273. A stay pending appeal is a matter of judicial discretion, Scripps-Howard Radio, Inc. v. FCC, 316 U.S. 4, 10-11 (1942), that might be issued in the hypothesized circumstances and might coincidentally give the defeudant time to inove into compliance. Where no appeal could in good faith be sought on the merits, however, strictly speaking it would be improper according to this analysis for a party to seek, or a judge to grant, a stay pending appeal solely to gain transition time.

If no party has requested immediate cessation, somewhat like the Rohm \& Haas case, discussed supra note 257 , could the court then refrain from ordering immediate coinpliance? It would seein that a decree is framed in light not only of private interests and private requests, but also of the public interest, lere dispositively declared by the statute. Thus, a court would be obliged to issue the immediate imjunction on its own motion.

A better response might be that a court does have continued discretion in tailoring its contempt sanction. Where a defendant has inade all reasouable atteinpts to reach compliance as quickly as possible in the circumstances, a court might well refrain from applying the severe penalties that could be attached to contempt violations. Insofar as the contempt proceeding is designed to punish disrespect for the court, United States v. Barnett, 346 F.2d 99, 100 (5tl Cir. 1965), a court could properly refrain froin punishing such a failure to achieve immediate compliance with the injunction. The balance, however, would be as to the subsequent question of criminal punishment for conteinpt, not as to the initial civil order of coinpliance.

Further, it should be noted that where traumatic stresses are threatened, the legislature can and does respond quickly to modify statutory provisions. See infra note 275 .

274. The language of an immediate compliance order deserves soune mention. If compliance is ordered "forthwith," it may mean "immediately." WEBSTER's NEW WORLD DictionaRY 549 (2d College ed. 1979). On the other hand, it may inean "with all reasonable celerity, not immediately," BALLENTINE's LAW DICTIONARY 492 (3d ed. 1969), which would open wide the barn door.

275. All of the statutes involved in the Reserve Mining litigation, discussed supro in text accompanying notes 167-78, except for the Refuse Act, offer good exainples of such built-in flexibility. See supra note 171 . Most inodern regulatory statutes delegate flexibility to administrative agencies. Courts, in practice, then review and shape exercises of agency discrction quite extensively. Compare, e.g., Clean Air Act Amendments of 1970, \& 4, 42 U.S.C. \& 1857c-4(b) (1976) with Kennecott Copper Co. v. EPA, 462 F.2d 846 (D.C. Cir. 1972).

276. For example, Congress responded quickly to amend the right-of-way restrictions for the 
be difficult for intermeddling plaintiffs to go to trial quickly enough for a court to consider the merits of their claims. Finally, the most compelling argument against a putative need for judicial overrides of statutes is our national history of more than two hundred tumultuous years, abounding with "emergencies" but devoid of cases allowing discretionary overrides.

In sum, with remarkable consistency over the years, the practice of the courts in the second area of equitable balancing has been to follow, without quite recognizing it, the logical distmctions that he at the foundation of Hecht Co. v. Bowles. This continuity has had practical consequences that fit well with the basic structure of our government.

\section{IV \\ Remands to the Legislature AND the Separation of POWERS}

\section{A. Examples of the Process}

The modern, truncated balance of equities in the face of statutory commands is well illustrated by several cases arising, like so inany major recent administrative law cases, in the area of environmental law. ${ }^{277}$ Each happened to imvolve violations that might be characterized as trivial or technical.

The trans-Alaska pipeline controversy was a major battle im the cainpaign to determine the future of a hundred million acres of Alaskan lands. The contending forces fought over issue of energy supply, local econormic development, native rights, dislocated national petroleum markets, relations with Canada and Japan, and inyriad National Environmental Policy Act questions including earthquake hazards, tundra and water quahity protection, wildlife ecology, inarime transport,

Alaskan pipeline, see infra text accompanying notes 29-30. A bill was passed in a matter of days to cope with a plague of blackbirds in Kentucky. Act of Feb. 4, 1976, Pub. L. No. 94-207, 90 Stat. 28. And just recently, Congress passed an entire interim budget in less than a week when President Reagan failed to sign their original effort. See N.Y. Times, Nov. 24, 1981, at A1, col. 6. This is not to ignore the reality that legislatures often respond, not to facts, but to pressures, which means that the defendant who lacks substantial political clout may not be able to get quick legislative action. This problem, which comes as no surprise to public interest advocates, directs attention toward the proper target-the improvement of the legislative process generally so that it can take account of facts. Rather than an abdication to the courts, this ultimately einphasizes the evolution of a pluralistic participation process in government.

277. Environmental cases often become leading administrative law cases, perhaps because they raise classic modern questions of third party participation in coinplex, long-term governmental decisionmaking. The term "environmental" is broad enough to include many of the most important public questions of health, safety, quality of life, and public participation in governinent. The only constant in the "environmental" cases is that the environmental proponents are seeking to bring non-market social, economic, and ecological values into governmental decisional processes that otherwise would exclude thein. 
and safety. ${ }^{278}$ Ultimately, however, the injunction that halted the Alaska pipeline project was based on an apparent triviality, an anachronistic limitation on the width of a right-of-way. Section 28 of the Mineral Lands Leasing Act of $1920^{279}$ limited pipeline rights-of-way on federal lands to a total of fifty feet plus the width of the pipe itself. Longstanding federal practice had been to ignore the strictures of section 28 , because modern pipeline construction requires a corridor of at least two hundred feet, with portions up to a thousand feet wide. ${ }^{280}$ The technical statutory violation was discovered, however, by thirdparty groups who were seeking to open up the ongoing administrative process to their various public interest concerns. ${ }^{281}$

The district court found a statutory violation. In an unreported decision, however, apparently after a classic balancing of equities, the court declined to issue a permanent injunction. ${ }^{282}$

The District of Columbia Court of Appeals, sitting en banc, had little trouble reversing. ${ }^{283}$ The court noted "the obvious magnitude and current importance of the interest[s] at stake: billions of gallons of oil at a time when the nation faces an energy crisis . . ., liundreds of millions of dollars in revenue for the State of Alaska . . ., industrial development and pollution of one of the last major unblemished wilderness areas in the world. . ." and continued:

But despite these elements . . ., the principles of law controlling these cases are neither complex nor revolutionary. . . . Congress, by enacting Section 28, allowed pipeline companies to use a certain amount of land to construct their pipelines. These companies have now come into court, accompanied by the executive agency authorized to administer the statute, and have said "this is not enough land; give us more." We have no nuore power to grant their request, of course, than we have the power to increase congressional appropriations to needy recipients. ${ }^{284}$

The court held, therefore, that it must "enjoin issuance of the special permit until Congress changes the applicable law."285 Neither the prof-

278. See Wilderness Soc'y v. Morton, 479 F.2d 842, 846 passim (D.C. Cir.), cert. denied, 411 U.S. 917 (1973).

279. 30 U.S.C. \& 185 (1976) (current version at Supp. III 1979).

280. See Wilderness Soc'y v. Morton, 479 F.2d 842, 848-51 (D.C. Cir.), cert. denied, 411 U.S. 917 (1973).

281. In the pipeline case, the right-of-way violation was used straightforwardly as a legal handle by which to win a tactically important injunction against further construction of the project. It is unsurprising to practitioners to find inajor cases turning upon technicalities, although the layperson's reaction may be that the plaintiffs "really don't care about" the width of a right-ofway. This indirectness of purpose poses no legal obstacle to plaintiffs, assuming that they otherwise have established the existence of a cause of action and their standing to sue.

282. See 479 F.2d at 846.

283. Wilderness Soc'y v. Morton, 479 F.2d 842 (D.C. Cir.), cert. denied, 411 U.S. 917 (1973).

284. Id. at 891 .

285. Id. at $847-48$. 
fered agency rulings nor arguments that the statute "served no legitimate purpose" could be allowed to thwart the clear statutory directive, the effect of which then was to "force the industry to coine back to Congress if the amount of land granted was insufficient for its purposes. Whether this restriction made sense then, or now, is not the busmess of the courts." 286 Neither the majority nor the dissent questioned the propriety or necessity of judicial deference to the statutory command. ${ }^{287}$

The role of equity was, in other words, a "remand to the legislature," 288 rather than a traditional balance of equities, even though there were public welfare equities aplenty to balance. In effect, the imdustry was sent to Congress for relief. Hearings on a bill to change section 28 were held a month after the Court of Appeals decision. The attorneys and plaintiff groups in the pipeline case testified on a wide range of issues relevant to the entire pipeline issue. ${ }^{289}$ The final result of the hitigation and the legislative process was the amendment of section 28 later the same year: the pipeline would contimue but with numerous new protections of the public domain, includimg advance federal corridor planning, improved pipe standards, improved shut-off valves, and close federal supervision of construction activities. ${ }^{290}$

The plaimtiff groups in the pipeline case, im short, won legislative consideration of their concerns and were able to convince Congress of the validity of some, though by no means all, of their objections. This public participation played a functional, albeit uncompensated, ${ }^{291}$ role in the development of what all parties ultimately regarded as a safer,

286. Id. at 892; see also id. at 912 (Wilkey, J., dissenting). Further, it should be noted that the expressed purpose of the statute (to limit the volume of land transferred) governed the court's statutory interpretation, not a judicial second-guessing of the legislators' specific intent (even though the members of Congress who wrote the Act clearly did not foresee that $\$ 28$ might frustrate the building of a pipeline). This approach parallels a basic distinction in statutory interpretation inade by Professors Hart and Sacks. H. HART \& A. SACKS, supra note 8, at 1411-17.

287. Only Judge MacKinnon, dissenting in part, would have allowed a federal permit to issue, and significantly he did so by arguing that the terms of the statute would not be violated if the permit were to be designated a revocable license instead of a right-of-way. $479 \mathrm{~F} .2 \mathrm{~d}$ at 898-905 (MacKinnon, J., dissenting in part). Judges Robb and Wilkey dissented in part on other issues. Id. at 912 (Robb, J., dissenting in part).

288. See J. SAX, supra note 13. It is a "Saxist" notion that citizen higation and administrative intervention are important in achieving a rational decisionmaking system in government by expanding a pohtically and legally effective inarketplace of ideas.

289. See, e.g., Hearings on H.R. 9130 to Amend Section 28 of the Mineral Leasing Act of 1920, and to Authorize a Trans-Alaska Pipeline and for Other Purposes Before the Subcomm. on Public Lands of the House Comm. on the Interior and Insular Affairs, 93d Cong., 1st Sess. 579-1179 (1973).

290. Trans-Alaska Pipeline Authorization Act, Pub. L. No. 93-153, \& 101, 83 Stat. 576 (1973).

291. Attorneys' fees were denied in Alyeska Pipeline Serv. Co. v. Wilderness Soc'y, 421 U.S. 240 (1975). 
more reliable Alaska pipeline. ${ }^{292}$ It can well be doubted whether the volunteer groups would have been able to obtain equivalent opportunities to make their case in Congress if the courts had permitted the pipeline to proceed in spite of the statutory violation. The District of Columbia Circuit's decision, in that instance enforced by an injunction, quite appropriately transferred the matter to Congress, structuring the subsequent legislative proceedings and the third-party groups' status therem. . $^{293}$

Narrow statutory violations have been the subject of numerous other cases where a district court otherwise may well have been tempted to balance the equities. In Izaak Walton League of America $v$. Butz ${ }^{294}$ the courts enjoined the practice of broad-swath cutting in the Monongahela National Forest. The plamtiffs alleged that the cutting caused erosion and deteriorating water quahty, but they based their suit on violations of the Forest Service Organic Act of 1897. ${ }^{295}$ The Act required that "the dead, matured or large growth" trees to be sold by the Service "shall be marked and designated,"296 a gross impracticality where modern contracts called for the cutting of substantially all trees in a stand. The courts again in effect remanded the industry to Congress for whatever amendments were necessary. ${ }^{297}$

By far the most dramatic recent example of the limited role of equity im statute-based hitigation was $T V A$ v. Hill, ${ }^{298}$ the notorious "snail

292. Even if in this case inost would agree that the enforcement of the statutory technicality ultimately served a useful function overall, it must be admitted that the proposition advanced here potentially permits the creation of tactical delays for any project or program, without regard to whether the delay is beneficial or disfunctional. The truth of that criticism is mitigated by the fact that litigation costs a great deal in terms of time and money, so that a fiood of negativistic lawsuits is unlikely im any event. Further, the proposition advanced in this Article is based, not on merits of tactical utihity, but rather on the merits of equity jurisprudence, separation of powers, and the pluralistic participation of multiple voices in governmental affairs. These latter merits continue in any case.

293. At least as to constitutional hitigation there are voices denying the appropriateness of such reinands. See Cox, Don't Overrule the Court, Newsweer, Sept. 28, 1981, at 18.

294. 522 F.2d 945 (4th Cir. 1974).

295. 16 U.S.C. $\$ \S 475-482$ (1976).

296. 522 F.2d at 947 (quoting 16 U.S.C. $§ 476$ (1976)).

297. The court declared:

Econo1mic exigencies, however, do not grant the courts a license to rewrite a statute no matter how desirable the purpose or result might be. . . W We are not insensitive to the fact that our reading of the Organic Act will have serious and far-reaching consequences, and it may well be that this legislation enacted over seventy-five years ago is an anachronisin which no longer serves the public interest. However, the appropriate form to resolve this coinplex and controversial issue is not the courts but the Congress.

Id. at 955. See also Named Individual Members of the San Antonio Conservation Soc'y v. Texas Highway Dep't, 446 F.2d 1013 (5th Cir. 1971), in which the Secretary of Transportation's failure to file a finding under $\S 4(f)$ of the Department of Transportation Act, 23 U.S.C. $\$ 138$ (1976), was the basis for an mjunction. A rider to the Federal-Aid Highway Act of 1973 was required to override the plaintiffs' objections. Pub. L. No. 93-87, § 154, 87 Stat. 250, 276 (1976).

298. 437 U.S. 153 (1978). 
darter" case. The citizen plaintiffs had sought for years to obtain congressional review of the social, economic, archaeological, recreational, ecological, and safety problems which attended the controversial Tellico Dam project in Tennessee. Usmg a somewhat coincidental violation of section 7 of the Federal Endangered Species Act; ${ }^{299}$ they obtained an injunction, even though by then over $\$ 20$ million had already been spent on the dam. ${ }^{300}$ Chief Justice Burger, writing for the majority, declared:

Our imdividual appraisal of the wisdom or unwisdom of a particular cause consciously selected by the Congress is to be put aside in the process of imterpreting a statute. Once the meaning of an enactment is discerned and its constitutionality determined, the judicial process comes to an end. We do not sit as a committee of review, nor are we vested with the power of veto. ${ }^{301}$

As the Court anticipated, ${ }^{302}$ the issue went to Congress. Extensive committee hearings took place, permitting a full factual review to occur in the proper political forums. ${ }^{303}$ Although the plaintiffs' position on

299. 16 U.S.C. $\$ 1536$ (1976) (current version at Supp. III 1979). According to the scientific testinony, the darter species had become endangered owing to the prior damming of 2500 miles of Tennessee rivers which had comprised most of its prior natural habitat. Hearings on 1978 Public Works Appropriations Before the Subcomm on Public Works Appropriations of the House Comm. on Appropriations, 95th Cong., 1st Sess. 240-41 (1977) (testimony of Tennessee Valley Authority witness).

300. As of the date of the Supreine Court hearing, the project had spent about $\$ 110$ inillion, most of it land acquisition, roads, landscaping, associated facilities, and administration and planning, although only slightly more than $\$ 20$ million lad been spent on the dam itself and associated levees. See Hearings on Amending the Endangered Species Act of 1973 Before the Subcomm. on Resource Protection of the Senate Comm. on Environmental and Public Works, 95th Cong., 1st Sess. 962 (1977) (TVA exhibit 8). Most of this expenditure was salvageable. GENERAL ACCOUNTing Office, Comptroller General of the United States, The Tennessee Valley Authority's Tellico Project-Costs, Alternatives, ANd Benefits $39-41$ (1977) (Report No. EMD-77-58).

301. 437 U.S. at 194-95. Note also that, in statutory interpretation terins, the courts followed the enunciated meaning and purpose of $\S 7$, not entering into a "legislators' intent" inquiry into what inembers of Congress would lave thought had they known that this little fish might obstruct a dam. See id. at 184 n.29; supra note 286.

302. In delivering the Court's majority opinion, Chief Justice Burger made it clear that he at least fully expected Congress to ainend the statute to change the result in Hill. Unfortunately, no record is kept of the Monday morning statements accompanying delivery of opmions of the Supreme Court. Conversation of author with Morton Mmtz of the Washington Post and Nima Totenberg of National Public Radio, both covering the Supreme Court (June 1978). See also 437 U.S. at 210 (Powell, J., dissenting).

303. The committees charged with substantive jurisdiction over the Act were the House Committee on Merchant Marine and Fisheries and the Senate Committee on Environinent and Public Works. House hearings on bills to exempt the Tellico project from the Act were held in 1978. Hearings on Implementation of Endangered Species Act of 1973 Before the Subcomm. on Fisheries and Wildlife and Environment of the House Comm. on Merchant Marine and Fisheries, 95th Cong., 2d Sess. (1978). Hearings also took place in the Senate, Hearings on Reauthorization of the Endangered Species Act of 1973 Before the Subcomm. on Resource Protection of the Senate Comm. on Environment and Public Works, 96th Cong., 1st Sess. (1979), as well as before the Endangered 
the economic merits prevailed in three sets of hearings on bills to amend the Act, the House Public Works Appropriations Subcommittee eventually managed to engimeer an exemption rider on the 1980 appropriation bill that permitted the project to proceed. ${ }^{304}$ Although the legal process of the Tellico controversy ultimately ended in a purely pohitical resolution, it was the Court's enforcement of statutory law that allowed the merits of the issue to be adduced in the legislative and administrative process.

The several examples noted here indicate that even in cases where the statutory violation appeared to be rather attenuated, judicial remands to the legislature permit the proper political processes to resolve controverted issues. When equity has confronted statutory violations over the years, the courts have confined themselves to enforcing the laws; legislatures have responded as necessary; and, as Alexander Bickel used to say, "the Republic has survived."

\section{B. Separation of Powers: A Question of Core Functions}

At the base of the Hill case and many others in this area of modern equity is the more or less fundamental allocation of governmental powers into three separate branches. The major contest in Hill was not over threshold equitable questions or the tailoring of remedies but about whether the agency's dam construction violated the statute. Once that had been determined the majority had no difficulty im deciding upon abatement. ${ }^{305}$ Answering Mr. Justice Rehnquist's assertion that trial courts could override statutory violations based on other significant public interest factors, the Court went back to its roots:

Our system of government is, after all, a tripartite one, with each Branch having certain defined functions delegated to it by the Constitution. While "[i]t is emphatically the province and duty of the judicial

Species Committee, a cabinet-level committee formed by the Act's 1973 amendments to grant exemptions, see Endangered Species Committee Decision (Jan. 23, 1979). The bills included S. 243, 96th Cong., 1st Sess. (1979); H.R. 3289, 96th Cong., 1st Sess. (1979); S. 2899, 95th Cong., 2d Sess. (1978); H.R. 4557, 95th Cong., lst Sess. (1977). The Act was amended in 1979. Endangered Species Act Amendments of 1978, Pub. L. No. 95-623, 92 Stat. 3757 (codified at 16 U.S.C. $\S \S 1532-1543$ (Supp. III 1979)).

304. See 125 CoNG. REC. H4663 (daily ed. June 19, 1979); Plater, Those Who Care About Laws and Sausages Shouldn' Watch Them Being Made, L.A. Times, Sept. 2, 1979, at 5, col. 1. As to the fish, several small remnant populations have since been found, so having served its indicator function the species inay yet survive its demise im the Little Tennessee River.

305. The dissent of Justices Powell and Blackmun argued on statutory construction grounds that the statute did not apply, based either on an imphed amendment by contimued appropriations, retroactivity estoppel, or a process of statutory remterpretation to avoid an "absurd result" that did not accord "with some modicuin of common sense and the public weal." 437 U.S. at 196 (Powell, J., dissenting). Subsequent courts have recognized the Hecht distinction as it was interpreted in TVA v. Hill. See, e.g., United States v. City of Paimesville, 644 F.2d 1186, 1193-94 (6th Cir. 1981). 
department to say what the law is," Marbury v. Madison, 5 U.S. (1 Cranch) 137, 177 (1803), it is equally and emphatically the exclusive province of the Congress not only to formulate legislative policies, mandate programs and projects, but also to establisli their relative priority for the Nation. Once Congress . . . has decided the order of priorities in a given area, it is for the Executive to administer the laws and for the courts to enforce them when enforcement is sought. ${ }^{306}$

Issues involving the separation of powers have most commonly surfaced in regard to statutory delegations of legislative powers ${ }^{307}$ where, for the most part, they no longer pose serious controversy. ${ }^{308}$ Although the Constitution's structure does provide for a basic separation of roles in the conduct of government, the doctrine of separation of powers has no explicit constitutional basis. Nevertheless, the shift from a legal systein dominated by common law to one dominated by statute inevitably touches on this foundation.

A potential confrontation between the courts and Congress lurks in the background of any discussion of the effect of statutes on judicial discretion. When the questions of choice of remedy and determination of permissible conduct are indiscriminately lumped together, the confrontation becomes real. Hecht drew the proper distinction between these two crucial questions. ${ }^{309}$ Otherwise, tlie Court's statement that

306. 437 U.S. at 194. To finish the job, the majority quoted from Bolt, "A Man for All Seasons":

"The law, Roper, the law. I know what's legal, not what's right. And I'll stick to what's legal. . . . I'm not God. The currents and eddies of right and wrong, which you find such plain-sailing, I can't navigate, I'm no voyager. But in the thickets of the law, oh there I'm a forester. . . . What would you do? Cut a great road through the law to get after the Devil? . . . And when the last law was done, and the Devil turned round on you -where would you hide, Roper, the laws all being flat? . . . This country's planted thick with laws from coast to coast-Man's laws, not God's-and if you cut them down ... d'you really think you could stand upright in the winds that would blow then? . . . Yes, I'd give the Devil benefit of law, for my own safety's sake."

437 U.S. at 195.

307. Despite Schecter Poultry Corp. v. Umited States, 295 U.S. 495 (1935) (holding that Congress may not delegate essential legislative functions to the executive branch), and Panaina Refining Co. v. Amazon Petroleum Corp., 293 U.S. 388 (1935) (same), and a rather more successful run in the state courts, the separation of powers delegation doctrine seems moribund. But see Industrial Union Dep't, AFL-CIO v. American Petroleum Inst., 448 U.S. 607, 675 (1980) (Relinquist, J., concurring) (expressing the view that \$6(b)(5) of the Occupational Safety and Health Act, 29 U.S.C. $\$ 655(b)(5)$ (1976), was invalid as violating constitutional rule prohibiting delegation of legislative power to executive branch). On the other hand, see Justice Relinquist's inajority opinion in Daines \& Moore v. Regan, 101 S. Ct. 2972, 2981 (1981) (when President acts pursuant to authorization of Congress, his acts are accorded strong presumption of validity). The basic separation of functions is imphicit im the structure of arts. I, II, and III and in the context in which they were written. Madison, The Federalist, No. 48, at 146 (J. Madison) (R. Fairfield ed. 1981). Justice Relinquist recently seeined to recognize the separation of functions distinction when he approvingly cited the Hill majority opinion in Milwaukee v. Illinois, 451 U.S. 304, 315 (1981).

308. The principle that Congress could not delegate legislative powers was not explicitly declared until Kilborn v. Thompson, 103 U.S. 168 (1881).

309. 321 U.S. at 328. 
"[a]n appeal to the equity jurisdiction . . . is an appeal to the sound discretion which guides the determinations of courts of equity" 310 would have sounded at the very least like an indirect challenge to legislative supreinacy. As it was, confrontation was avoided when the Court deferred matter-of-factly and coinpletely to Congress' statutory definition of permissible pricing conduct, while applying a very strmgent judicial test to the putative congressional restriction of the courts' choice of remedy in implementing the law. Congress defined the rules of pricing conduct but, absent explicit language, the Court refused to presume that the legislature had also dictated the form of remedy.

To be sure, it would fit the present analysis of limited judicial discretion most conveniently if we could develop a set of immutable definitions of some governmental functions as legislative in nature and others as inherently judicial. The proscription of particular conduct would then clearly be a power reserved to the legislatures, to be exercised when and as they chose. It would, however, be an "archaic view of the separation of powers" to believe that public decisionmaking functions could be separated into "three airtight departments of government." 311 The courts have never lield that the actions of the three branches may not overlap with one another. ${ }^{312}$

Yet certain areas of governmental activity seen to lie at the core of each branch's constitutional function, and it is here that the doctrine of separation of powers retains practical legal efficacy. If Congress undertakes the executive task of nominating officers for an executive agency, ${ }^{313}$ or invades a specific adjudicatory proceeding in the executive branch or elsewhere, ${ }^{314}$ or if the executive branch arrogates to itself the power to inake substantive law without congressional delegation, ${ }^{315}$ the issue is not whether the lines between the three branches are blurring or overlapping. In these exainples, one branch is taking over the

310. Id. at 329 (quoting Meredith v. Winter Haven, 320 U.S. 228, 235 (1943)).

311. Nixon v. Administrator of Gen. Servs., 433 U.S. $425,441-43$ (1977).

312. As a principle of statesmanship the practical demands of government preclude . . . doctrinaire application [of the concept of separation of powers, which is] a "political doctrine" and not a technical rule of law. . . . From the beginning [the Supreme] Court has refused to draw abstract, analytical tines of separation and has recognized necessary areas of interaction.

Frankfurter \& Landis, Power of Congress over Procedure in Commerical Contempts in "Inferior" Federal Courts-A Study in Separation of Powers, 37 HARv. L. Rev. 1010, 1012-14 (1924).

313. See Buckley v. Valeo, 424 U.S. 1, 109-43 (1976).

314. Pillsbury Co. v. FTC, 354 F.2d 952 (5th Cir. 1966).

315. This describes the standard ultra vires problem. See Youngstown Sheet \& Tube Co. v. Sawyer, 343 U.S. 579 (1952), especially the concurring opinion of Justice Frankfurter: "When Congress itself has struck the balance . . a court of equity is not justified in ignoring that pronouncement under the guise of exercising equitable diseretion." Id. at 609-10 (Frankfurter, J., concurring). The assertion of a judicial power to permit noncompliance with statutes would seem to fall into Justice Jackson's third category of alleged powers which contradict the realm of Congress' powers, and hence should be inost strictly limited. Id. at 635-40 (Jackson, J., concurring). 
core function of another. Similarly, when a court is asked to exempt a defendant from a legislative enactment, it is being imvited to take over a core function of the legislature. Conversely it exercises its own core function when it enforces legislative statutes in apphicable factual situations. ${ }^{316}$

Judicial deference to legislative enactments has hardly been a controversial practice in the United States, or, for that matter, within the English legal system during the centuries in which both Parliament and equity evolved. ${ }^{317}$ It reflects a commonly expressed aversion to judicial legislating. Judicial discretion in fashioning remedies effectuating the legislative mandate, on the other hand, is equally matter-of-factly accepted as falling within the conventional precincts of the judiciary. Hence, its retention can be more easily and zealously defended. ${ }^{318}$

The intervention of Congress to define a substantive rule to be applied at the second stage of equity litigation does not ineluctably con-

316. As the court said in the Alaska pipeline case:

In the last analysis, it is an abiding function of the courts, in the course of decision of cases and controversies, to require [defendants] to abide by the limitations prescribed by the Legislature. The scrupulous vimdication of that basic principle of law, implicit in our form of government, its three branches and its checks and balances, looms more important in the abiding public interest than the embarkation on any immediate or specific project, however desirable in and of itself, in contravention of that principle.

Wilderness Soc'y v. Morton, 479 F.2d 842, 892-93 (D.C. Cir.), cert. denied, 411 U.S. 917 (1973).

317. Judicial deference to legislative determinations about permitted and proscribed conduct is consistent with the functional principles of separation of powers as they evolved in England. In the absence of statutes, equity and law acting together developed causes of action and rules of conduct-the substantive stuff of lawsuits-as well as procedures and remedies. The making of statutes as we know them was virtually nonexistent prior to the 16th century. In a legal system monopolized by court-made law, the question of who would decide substantive rules of conduct was usually moot. Prior to the Reformation Parliaments of the 1500's, substantive parliamentary acts generally did little more than declare a consensus of prior court-made standards. After the Refornation Parhaments, however, the primary purpose of statutes often was to declare new substantive rules as well. Some of these altered and replaced court-made rules; others were coinpletely novel, designed in intricate detail to handle problems outside the ken of common law. In either case, legislation, then as now, stepped in and did in a parliamentary moment what might have taken the courts decades of case law to accomplish. Whenever King and Parliament did pass a law, the "who" question was decisively shifted to the legislature, and the equity courts liad to accept the change. The Chancellor, after all, was the King's servant. In the constitutional crucible of Tudor and Stuart England, the courts may have fought artfully indirect battles for their prerogatives, but even then a statute, once passed, was obeyed to the letter by the courts of chancery (though they might do their utmost to avoid its spirit, as they did, for example, with the Statute of Uses). See generally 4 W. Holdsworth, supra note 47, 450-6I (1924). Adherence to the mandates of parhamentary statutes was a longstanding implicit principle in English government and was expressly enshrined in the 17th Century Bill of Rights after James the Second had ignored it and was deposed. The author is indebted to Professor Charles Donahue, Jr. of the Harvard Law School for his patient and impassioned reconstruction of five centuries of legal history underpinning this footnote.

318. If, as one contemporary observer reflected, the Heclit Company had argued that a district court itself could redetermine the statutory definition of proscribed price fixing conduct, instead of inerely determining remedies, "the Court would not have wasted mucli time on that argument." James interview, supra note 79. 
strain the first and third areas of judicial discretion. No core judicial function is threatened by the statutory definition of proscribed and permitted conduct. The moment that a district court judge sitting in equity begins to consider, whether a valid statute must be obeyed, however, the judicial system departs from the careful boundaries that have been maintained in this country over two centuries and invades the core function of the legislature. As the Chief Justice wrote four years ago, "[I]n our constitutional systein the commitment to the separation of powers is too fundamental for us to preeinpt congressional action by judicially decreeing what accords with 'common sense and the public weal.' Our Constitution vests such responsibilities in the political branches." ${ }^{319}$

\section{CONCLUSION}

To most nonlawyers the analysis advanced here-that a court confronted with a violation of statutory law cannot permit that violation to continue-is self-evident. If a legislature prohibits an action, it is prohibited. To judges and attorneys steeped in the common law tradition of judicial flexibility, however, it is initially a discomfiting proposition.

Nevertheless, if equitable discretion in traditional nonstatutory litigation is separated analytically into its three component functions, the statutory cases reveal a reinarkable consistency with the proposition of limited discretion. Over the years, without recognizing the principle clearly, courts have uniformly refused to substitute their own judginent for the legislature's on the question of which conduct is to be permitted and which abated. Equitable discretion reinains in the threshold balances which admit parties to the equity forum, and in the balancing which helps fashion particular reinedies, but statutory coinpliance there inust be.

By consistently drawing this line in practice, the courts have avoided the difficulties inherent in any attempt to define an equitable power to override legislative commands, a process that would be both unnecessary and constitutionally hazardous. This equitable discretion, moreover, with its fundainental deference to the legislature, has practical consequences that accord well with our nation's evolving theories of pluralistic democracy.

\section{AUTHOR's POSTSCRIPT}

While this Article was in press, the Supreme Court decided the case of Weinberger $v$. Romero-Barcelo, ${ }^{320}$ in favor of the Navy petition-

319. TVA v. Hill, 437 U.S. 153, 195 (1978).

320. 50 U.S.L.W. 4434 (U.S. Apr. 27, 1982); see supra text accompanying notes 243-63. An 
ers. Writing for the majority, Justice White seemed to assert a very broad scope for an equity court's discretionary power "to arrive at a 'nice adjustment and reconciliation' between ... competing claims," primarily relying on the broad language of Hecht and nonstatutory equity cases. ${ }^{321}$ This wide traditional discretion remaimed unimpaired by statutes unless Congress evidenced an intention "to depart from established principles." 322 If the opinion is to be read that broadly, then as Justice Stevens noted im dissent, the majority had failed to discern the "two critical distimctions" embodied in the holding of Hecht and other equity cases: distimctions between private law and public law cases, and between "those cases im which there is no danger that a past violation of law will recur" and "those in which an existing violation is certain to continue." 323 By not making these distimctions, according to Justice Stevens, the Court "unnecessarily and casually substitutes the Chancellor's clumsy foot for the rule of law."324

Despite the broad pronouncements in the first half of the opinion, the Court's holding appears to have been limited to the assertion of a discretion to permit noncomplance while defendants seek to end their violations, not a discretion to permit statutory noncompliance. ${ }^{325}$ So limited, the majority's opinion still presents the serious analytical problems involved in permitting delayed compliance, ${ }^{326}$ but not on such a far-reaching scale as a general declaration of discretionary au-

advance draft of this Article had been supplied to the Court and both parties, and was used by respondents in developing their briefs and oral argument to the Court.

321. Id. at 4435 (quoting Hecht, discussed supra text accompanying notes 86-112); see also id. at 4436-37. 1t is unfortunately beyond the scope of this last-mimute addendum to note the variety of nonstatutory cases cited in support of the majority's position. Justice Powell, in a brief concurrence, would simply liave directed the court of appeals to accept the district court's exercise of discretion. Id. at 4438 (Powell, J., concurring).

322. 50 U.S.L.W. at 4436 (citing Hecht); see also id. at 4437 . The majority argued that Congress liad evidenced such an intent in the statute involved in TVA $v$. Hill. Id. at 4436. The specific exeinption provision included in the Federal Water Pollution Control Act Amendments of 1972, $\S 313,33$ U.S.C. $\S 1323$ (Supp. III 1979), was dismissed by the Court as a Congressional provision for permitting permanent noncompliance, rather than a limitation of a trial court's discretion to permit statutory noncomphiance while violations were being corrected. Romero-Barcelo, 50 U.S.L.W. at 4437; see infra note 325 and accompanying text.

323. Romero-Barcelo, 50 U.S.L.W. at 4439 (Stevens, J., dissenting).

324. Id. at $4441-42$ (Stcvens, J., dissenting). The majority, by failing to appreciate that past holdings allowing discretionary flexibility in statutory cases involved only threshold questions, see supra notes 156-65 and accompanying text, and the choice of remedy, see supra notes 169-88 and accompanying text, was able to presume that equity had always balanced everything, and thus cast the question as whether "Congress intended to deny courts their traditional equitable discretion in enforcing the statute." $J d$. at 4436 (majority opimion).

325. Thus, the inajority spoke of "traditional equitable discretion in enforcing the statute," $i d$. at 4436 (einphasis added); the district court had only "temporarily, not permanently, allowed the Navy to continue," $i d$;; there were "remedies other than an immediate prohibitory injunction" that could "achieve compliance with the Act." Id. at 4436-37 (emphasis in original).

326. See supra notes $264-76$ and accompanying text. 
thority. The majority opinion also seemed to reconsider whether the statute had actually been violated. ${ }^{327}$

The majority did not discuss the implications of the RomeroBarcelo holding upon the separation of powers; nor did it articulate what standard, if any, would limit a district court in substituting its judgment for that of the legislature. Moreover, the majority indicated that the Romero-Barcelo case may well require different considerations on remand if the Navy's application for a discharge permit were demed, a possibility that has now occured ${ }^{328}$ In these circumstances, it appears likely that the debate reflected in the Romero-Barcelo opinions and this Article will continue. This Article has demonstrated that, over the years, there have been many statutory equity cases in which judges have exercised discretion, but never so as to override the specific prohibitions of a statute. Now there is one.

327. Justice White indicated that the permit procedure was a remedy designed to achieve statutory compliance, and argued that the purpose of the statute was clean water, not the issuance of permits per se. Thus, according to the majority's interpretation of the Federal Water Pollution Control Act, the lack of a permit did not necessarily constitute statutory noncompliance. RomeroBarcelo, 50 U.S.L.W. at $4436-37$.

328. Id. at 4437-38.

The Commonwealth of Puerto Rico has denied the water quality certificate required; the Navy is currently seeking to overturn that decision in district court. Id. at $4436 \mathrm{n} .9$; see also United States v. Commonwealth of Puerto Rico, No. 82-0726 (D.P.R. filed Mar. 25, 1982).

Where a permit is not hikely to issue, "the requirements and objectives of the statute could ... not be vindicated ... [which] would require the court to reconsider the balance it has struck." Romero-Barcelo, 50 U.S.L.W. at 4438. If a permit denial is indeed necessary to constitute a statutory violation, such is now the case. Faced with a statutory violation, the reviewing court can, on remand, be expected to grant particular weight to Congress's declaration of the public interest as enbodied in the statute. See supra notes 99-101 and accompanying text; see also supra text accompanying notes 166-73. Further, in light of the majority opinion's restricted definitions of discretion, see supra note 325 , it would seem hikely that once a violation has been inescapably established, the balance is then definitely settled in favor of compliance with the Act, and discretion accordingly limited as deinonstrated in this Article. 